\title{
Re-Examining the Constitutionality of Remittitur Under the Seventh Amendment
}

\begin{abstract}
SuJA A. THOMAS*
The modern scholarly discussion of remittitur has been largely limited to the appropriate standards for applying the doctrine and to the appellate review of the motion. Moreover, the Supreme Court's discussion of the constitutionality of remittitur under the Seventh Amendment was dicta and focused only on whether remittitur violated the defendant's constitutional rights. This article takes a new look at the constitutionality of remittitur. The Seventh Amendment uniquely requires that the re-examination of facts determined by a jury should be only according to the "rules of the common law." A review of the text of the Seventh Amendment's re-examination clause, as well as the Supreme Court jurisprudence on the Seventh Amendment, suggest that the English common law in 1791 should influence the analysis of the constitutionality of remittitur. This article examines for the first time the English common law on remittitur and the new trial for excessive damages. The study shows that English courts did not employ remittitur to reduce verdicts. Accordingly, it can be argued that remittitur is unconstitutional. A view of the common law as fixed or static, based only on the English common law, may not be accepted, however. Using an interpretation of the common law in the re-examination clause as, not fixed or static based only on the common law, but as evolving, this article argues that the result is the same; remittitur is unconstitutional. Under an interpretation of the common law as evolving, for remittitur to be constitutional, the plaintiff must have the option of taking a new trial as an alternative to accepting the remittitur. Effectively, under the practice of remittitur, plaintiff does not have this option. An original study of remittitur decisions in the federal courts over ten years was conducted and is used to support the conclusion that remittitur effectively eliminates plaintiff's right to a jury trial.
\end{abstract}

\section{INTRODUCTION}

In 1822 , the practice of remittitur emerged in the federal courts. In Blunt $v$. Little, ${ }^{1}$ after a trial by jury, the defendant moved for a new trial because the jury

* Assistant Professor, University of Cincinnati College of Law. J.D., New York University School of Law; B.A., Northwestern University. I give special thanks to my research assistant, Tod Thompson, who made invaluable contributions to this article. I am also grateful for the comments of the following individuals: Jack Chin, Ruth Colker, Howard Erichson, Rafael Gely, Kelly Gilchrist, John C.P. Goldberg, Mitu Gulati, Steve Ingram, Nancy Marder, Jason Mazzone, Colleen Murphy, Donna Nagy, James Oldham, Wendy Parker, Catherine Sharkey, Michael Solimine, Ellen Sward, Michael Van Alstine and Ingrid Wuerth. Alex Gray, a law student, helped prepare appendix A.

$1^{4}$ F. Cas. 760 (C.C.D. Mass. 1822) (No. 1578). 
allegedly had rendered excessive damages. ${ }^{2}$ Justice Story determined a damages amount that he found reasonable and decided that the plaintiff could accept this amount as an alternative to a new trial. ${ }^{3}$ Since then, the practice has grown. In recent jurisprudence, United States Supreme Court Justices have encouraged the use of this practice as a way to control damages rendered by juries in civil rights cases. ${ }^{4}$ This endorsement of remittitur and its widespread use in the federal courts $^{5}$ are curious when viewed in conjunction with the Court's decision sixty years earlier that the constitutionality of remittitur was doubtful precedent. Courts have accepted remittitur as constitutional based on an inaccurate historical assumption that the practice existed at English common law in the eighteenth century. Additionally, the constitutionality of this practice has rested on the faulty presumption that the plaintiff could take a new trial instead of the remitted verdict.

According to the Seventh Amendment, facts found by a jury may be reexamined only "according to the rules of the common law." When a court decides that a jury verdict is excessive, the court orders a new trial or alternatively, a remittitur of the damages rendered by the jury. The judge decides the maximum amount of damages that a reasonable jury could award under the evidence presented at the trial. By ordering the new trial or alternative remittitur, the court re-examines facts-the damages-found by the jury. This practice will be constitutional under the Seventh Amendment if such re-examination is according to the rules of the common law.

The constitutionality of the practice of remittitur rests on dicta from the 1935 case of Dimick v. Schiedt. ${ }^{7}$ There the Supreme Court considered whether additur, the increase of a jury verdict by a court, was unconstitutional. ${ }^{8}$ If a practice existed at English common law in 1791, the time of the adoption of the Seventh Amendment, the practice was considered to be a rule of the common law and

2 See id. at $761-62$.

${ }^{3}$ See id. at 762 .

${ }^{4}$ See Gebser v. Lago Vista Indep. Sch. Dist., 524 U.S. 274, 302 n.12 (1998) (Stevens, Souter, Ginsburg \& Breyer, JJ., dissenting) (stating, in the context of a Title IX case, that " $[\mathrm{t}] \mathrm{he}$ lower courts are not powerless to control the size of damages verdicts. ... Courts retain the power to order a remittitur.").

5 See William V. Dorsaneo, III, Reexamining the Right to Trial by Jury, 54 SMU L. REV. $1695,1727(2001)$ (stating that remittitur is a "practice... widely used by trial courts in the federal system"); Big Gets Bigger: Reductions; 2000 Awards that Shrank, NAT'L L.J, Feb. 19, 2001 , at C23 (stating that a verdict "not reduced by trial or appellate courts was a relative rarity").

${ }^{6}$ U.S. CONST. amend. VII. The Seventh Amendment provides that "[i]n Suits at common law, where the value in controversy shall exceed twenty dollars, the right of trial by jury shall be preserved, and no fact tried by jury, shall be otherwise re-examined in any Court of the United States, than according to the rules of the common law." Id.

7293 U.S. 474 (1935).

${ }^{8}$ See id. 
thus, constitutional under the re-examination clause of the Seventh Amendment. ${ }^{9}$ Under a review of the common law, the Court found no evidence of additur. ${ }^{10}$ However, because federal courts used remittitur to decrease jury verdicts, the Court analyzed whether courts also should use the analogous practice of additur to increase verdicts. ${ }^{11}$

It was thus only in the context of considering the practice of additur that the Court discussed the constitutionality of remittitur. ${ }^{12}$ The Court emphasized some apparent, although uncited, English common law practice of reducing jury verdicts and the use of remittitur over many years by the federal courts. ${ }^{13}$ Referring to the constitutionality of remittitur as "doubtful precedent," however, the Court refused to extend this "precedent" to additur and instead found additur unconstitutional..$^{14}$ Yet the Court further opined that the constitutionality of remittitur should not be revisited in the future. ${ }^{15}$

This article takes a new look at the constitutionality of remittitur. It presents the results of two original studies, one study of the English common law on remittitur in 1791, when the Seventh Amendment was adopted, and another of remittitur by the federal courts over a ten-year period. ${ }^{16}$ Considered alone and together, these studies show that remittitur is unconstitutional.

${ }^{9}$ See id. at 476-77.

10 See id. at $476-82$.

11 See id. at $482-83$.

12 See id. at $485-88$.

13 See Dimick, 293 U.S. at 485-88.

14 See id.

15 See id. at $484-85$.

16 There has been extensive commentary on remittitur but none conducts, as does this article, the study of the common law or the analysis of current remittitur practice. See, e.g., David Baldus et al., Improving Judicial Oversight of Jury Damages Assessments: A Proposal for the Comparative Additur/Remittitur Review of Awards for Nonpecuniary Harms and Punitive Damages, 80 IowA L. REv. 1109 (1995); Leo Carlin, Remittiturs and Additurs, 49 W. VA. L.Q. 1 (1942); Fleming James, Jr., Remedies for Excessiveness or Inadequacy of Verdicts: New Trial on Some or All Issues, Remittitur and Additur, 1 DUQ. L. REV. 143 (1963); Irene Deaville Sann, Remittitur (and Additur) in the Federal Courts: An Evaluation with Suggested Alternatives, 38 CASE W. RES. L. REV. 157 (1987); Brad Snyder, Protecting the Media from Excessive Damages: The Nineteenth-Century Origins of Remittitur and Its Modern Application in Food Lion, 24 VT. L. REV. 299 (2000); Victor M. Casini, Note, O'Gilvie v. International Playtex, Inc.: An Improper Remittitur of a Punitive Damages Award, 81 Nw. U. L. REV. 288 (1987); David Fink, Comment, Best v. Taylor Machine Works, The Remittitur Doctrine, and The Implications for Tort Reform, 94 Nw. U. L. REV. 227 (1999); Note, Constitutional LawRight to Jury Trial-Judicial Use of Additurs in Correcting Insufficient Damage Verdicts, 21 VA. L. REV. 666 (1935) [hereinafter Judicial Use of Additurs]; Comment, Correction of Damage Verdicts by Remittiturs and Additur, 44 YALE L.J. 318 (1934) [hereinafter Correction of Damage Verdicts]; James C. Lopez, Comment, Appellate Control of Excessive Jury Verdicts Since Gasperini v. Center for Humanities: From Nisi Prius Courts to "Gasperini Hearings", 66 U. CIN. L. REV. 1323 (1998); Christian J. Mixter, Note, Appealability of Judgments Entered 
This article's study of the English common law shows that English courts did not remit jury verdicts in the same manner that United States' federal courts do today. At English common law, "remittitur" was simply a device used by plaintiffs to correct defects in their pleadings, ${ }^{17}$ not a discretionary tool used by judges to reduce damages found by a jury. In fact, English courts granted such new trials only in cases in which the damages were calculable, such as contract cases, not where damages were uncertain, such as tort cases.

While the English practice in 1791 has been an important consideration in the analysis of the constitutionality of a practice under the Seventh Amendment, when interpreting the common law in the Seventh Amendment, the Supreme Court and legal scholars have gone beyond this English practice. ${ }^{18}$ Under some jurisprudence and scholarship, whether a practice is constitutional under the Seventh Amendment should rest on an "evolving" common law. ${ }^{19}$ Implicit in this view of the common law as evolving is whether the challenged practice maintains the role of the jury as the fact-finder as it functioned at common law. ${ }^{20}$ Thus, if one accepts this evolving view, remittitur is constitutional if the practice provides an additional option for the plaintiff that does not impinge his right to a jury trial. In other words, remittitur is constitutional if the plaintiff can choose between a new trial and the remittitur.

A look at the practice of remittitur in the federal courts shows, however, that remittitur in fact does impinge the plaintiff's right to a jury trial and is thus unconstitutional. When faced with the possibility of a new trial or alternatively, a remittitur, the plaintiff has no real choice to take the new trial. The plaintiff will take the remittitur or settle the case. The plaintiff will not take the new trial because even if the second trial results in a verdict that is greater or the same as the previous jury's verdict, the same judge will oversee the case, and that judge has already determined the maximum amount that a reasonable jury could award under the facts.

Consider this typical case: A plaintiff sues alleging that the defendant company discriminated against him. ${ }^{21}$ After the jury finds in favor of the plaintiff and awards economic damages of $\$ 135,000$ and emotional distress damages of

Pursuant to Remittiturs in Federal Courts, 1975 DUKE L.J. 1150 (1975); Michael A. Newsom, Comment, Additur and Remittitur in Federal and State Courts: An Anomaly?, 3 CUMB. L. REV. 150 (1972); Barbara Lemer, Comment, Remittitur Review: Constitutionality and Efficiency in Liquidated and Unliquidated Damage Cases, 43 U. CHI. L. REV. 376 (1976); Irene Sann, Note, Remittitur Practice in the Federal Courts, 76 COLUM. L. REV. 299 (1976) [hereinafter Sann, Remittitur Practice]; William H. Wagner, Note, Procedures to Lessen Remittitur's Intrusion on the Seventh Amendment Right to Jury Trial, 1979 WASH. U. L.Q. 639 (1979).

17 See infra text accompanying notes 152-78.

18 See infra notes $114-44$ and accompanying text.

${ }^{19}$ See id.

20 See id.

${ }^{21}$ See Schanzer v. United Techs. Corp., 120 F. Supp. 2d 200, 202 (D. Conn. 2000). 
$\$ 175,000$, the defendant argues that the jury rendered an excessive emotional distress award and requests a new trial or a remittitur of the emotional distress damages. ${ }^{22}$ The judge decides that a reasonable jury could have awarded only a maximum of $\$ 40,000$ for the emotional distress that was suffered and grants the motion for a new trial unless the plaintiff accepts a remittitur of these damages from $\$ 175,000$ to $\$ 40,000 . .^{23}$ Now, although the plaintiff won the jury trial, the plaintiff is left with a Hobson's choice: retry the case although the judge has already declared the maximum amount that a jury could award under the facts; accept the remittitur to $\$ 40,000$; or settle the case with significantly less power to negotiate with the defendant. Upon the judge's determination that $\$ 40,000$ is the maximum that a reasonable jury could find for emotional distress, the plaintiff effectively has no real choice to take the new trial because the plaintiff believes that the judge will reduce any subsequent jury verdict greater than $\$ 40,000$. In this particular example, the plaintiff forwent the new trial and accepted the remittitur. ${ }^{24}$

Indeed, this article's study of remittitur in the federal district courts for the ten years from 1991 through 2000 demonstrates that remittitur effectively eliminates the plaintiff's constitutional right to have damages tried by a jury because the alternative of a new trial is not truly an option for the plaintiff. The study found that when judges remitted jury verdicts, in $98 \%$ of the cases the plaintiff either accepted the remittitur (in $71 \%$ of the cases) or settled the case (in $27 \%$ of the cases). In only $2 \%$ of the cases did the plaintiff take the new trial. It is noteworthy that federal judges use this unconstitutional practice to reduce uncertain damages, damages that cannot be calculated with mathematical certainty, for example, emotional distress damages. Of the remitted cases studied, $68 \%$ included uncertain damages as a component, $46 \%$ of which were emotional distress damages and $50 \%$ of which were in civil rights cases. In this subset of cases which involve uncertain damages, the study again shows that the new trial option is illusory. In $98 \%$ of these cases, the plaintiff accepted the remittitur or settled.

Part I of this article describes the federal practice of remittitur and describes the study of remittitur in the federal district courts over ten years. The study shows that remittitur has effectively eliminated the plaintiff's right to a jury trial on damages and that judges use this unconstitutional practice to reduce uncertain damages, including damages in civil rights cases.

Part II describes the Supreme Court's decision in Dimick. This Part also discusses the jurisprudence and commentary regarding the re-examination clause

${ }^{22}$ See id. at 202, 216.

23 See id. at 216-20.

${ }^{24}$ See app. A. In this case, the jury also found the defendant had discriminated against the second plaintiff. See Schanzer, 120 F. Supp. 2d at 202. The jury awarded $\$ 130,000$ in economic damages and $\$ 175,000$ in emotional distress damages. See id. The court also remitted this emotional distress award from $\$ 175,000$ to $\$ 45,000$. See $i d$. at 216-20. Again, the plaintiff accepted the remittitur. See app. A. 
of the Seventh Amendment. It concludes that the constitutionality of remittitur should be decided based on whether remittitur existed at English common law in 1791. It also alternatively recognizes a view of the common law as evolving such that remittitur is constitutional if the practice maintains the role of the jury as the fact-finder to the extent it functioned as such at English common law.

Part III then examines the English common law in the 1791 period, as well as, for comparison purposes, the American common law in that time period. The English common law cases show that remittitur was a practice used by plaintiffs to correct errors in the pleadings, not a device used by judges to reduce jury verdicts. The cases also demonstrate that judges did not remit verdicts as an alternative to the new trial for excessive damages. The study concludes that English courts did not remit jury verdicts as federal courts do today. Thus, under a static (or fixed) approach to the re-examination clause, remittitur is unconstitutional. Moreover, even if one accepts the conception of an evolving common law, remittitur is unconstitutional because remittitur effectively eliminates the plaintiff's right to have damages determined by a jury. The plaintiff has no choice but to take the judge-remitted verdict or settle the case based on the judge's determination. Finally, to the extent that Dimick continues to be recognized as precedent for the constitutionality of remittitur, it should be overruled. The importance of the preservation of the Seventh Amendment right to a jury trial outweighs any concern that the elimination of remittitur may affect judicial efficiency.

\section{REMITTITUR IN THE FEDERAL COURTS}

\section{A. "Remittitur" Defined}

For some time, judges have ordered new trials for excessive damages or alternatively, remitted damages ${ }^{25}$ when the damages are said to "shock the

25 See Gasperini v. Ctr. for Humanities, Inc., 518 U.S. 415,433 (1996). At English common law, courts granted new trials. See id. at 432-33 (citing 6A MOORE'S FEDERAL PRACTICE I 59.05[1], at 59-38 to 59-40 (2d ed. 1996)). Congress codified the English practice by passing the Judiciary Act of 1789, which gave United States' courts " 'the power to grant new trials, in cases where there has been a trial by jury for reasons for which new trials have usually been granted in the courts of law.' " II CHARLES ALAN WRIGHT ET AL., FEDERAL PRACTICE AND PROCEDURE $\S 2801$, at 41 (2d ed. 1995) (quoting Judiciary Act of 1789, $\S 17,1$ Stat. 83). This section of the Judiciary Act was repealed when it was replaced by Federal Rule of Civil Procedure 59. See id. Under Rule 59(a), "[a] new trial may be granted ... in an action in which there has been a trial by jury, for any of the reasons for which new trials have heretofore been granted in actions at law in the courts of the United States." See FED. R. CIV. P. 59(a). In addition to granting a new trial for excessive damages, a judge may grant a new trial for, inter alia, the admission of improper evidence and the giving of improper jury instructions. See 11 WRIGHT ET AL., supra, $\$ \S 2806,2810$. In contrast to other new trial motions, in 
judicial conscience of the court."26 Although a seemingly high threshold for ordering a new trial or reducing a jury verdict, this standard has essentially become a reasonableness determination. ${ }^{27} \mathrm{~A}$ judge looks at the evidence in the case at hand and decides, based on her own experiences ${ }^{28}$ or based on other cases with "similar" facts, ${ }^{29}$ whether the jury awarded excessive damages. ${ }^{30}$ If the

excessive damages cases, the judge may offer the plaintiff a remittitur of the verdict, as an alternative to the new trial. See id. $\S 2807$, at 86 .

26 See, e.g., Crowley v. Cooperstein, No. CIV.A.90-0009, 1992 WL 129631, at*1 (E.D. $\mathrm{Pa}$. June 9, 1992) ("Remittitur is appropriate when no clear judicial error or "pernicious influence' can be identified but where the verdict is so large as to shock the conscience of the court."). Justice Scalia has criticized this standard as having no basis in English common law. See Gasperini, 518 U.S. at 466 \& n.11 (Scalia, J., dissenting); see also infra Part III.B.3 (describing the English common law on new trials for excessive damages).

State courts also remit jury verdicts deemed "excessive," $c f$. Dardinger v. Anthem Blue Cross \& Blue Shield, 781 N.E.2d 121, 145-46 (Ohio 2002) (remitting a punitive damages award and uniquely requiring that a significant portion of the remitted award be given to a hospital), and sometimes a state statute specifies a standard for excessiveness. In New York, for example, an award is excessive when it " deviates materially from what would be reasonable compensation.' " See Gasperini, 518 U.S. at 418 (quoting N.Y. CIV. PRAC. LAW AND RULES $\S 5501$ (c) (McKinney 1995)). A jury verdict is more easily excessive under the New York state standard than the federal standard. See id. at 423-24; Shea v. Icelandair, 925 F. Supp. 1014, 1021 n.3 (S.D.N.Y. 1996) (discussing compatibility of standards). This article concems only the constitutionality of remittitur as applied in federal court under the Seventh Amendment. A state standard for excessiveness would apply in diversity cases in federal court and thus in that context the state standard must be constitutional under the Seventh Amendment. See Gasperini, 518 U.S. at $437-38$.

Additionally, this article concerns the remittitur of damages only because the damages are deemed excessive, not because they are deemed unconstitutional. A certain amount of punitive damages may be unconstitutional and thus subject to remittitur. Compare BMW of N. Am., Inc. v. Gore, 517 U.S. 559 (1996) (deciding that punitive damages award of \$2 million, which was 500 times the actual harm to the plaintiff, was unconstitutional), and State Farm Mut. Auto Ins. Co. v. Campbell, 123 S. Ct. 1513, 1524-26 (2003) (deciding that punitive damages award of $\$ 145$ million, where actual harm to the plaintiff was $\$ 1$ million, was unconstitutionally excessive), with TXO Prod. Corp. v. Alliance Res. Corp., 509 U.S. 443 (1993) (holding that although actual damage was only $\$ 19,000, \$ 10$ million punitive damages award was not unconstitutionally excessive). There is conflict over whether courts can remit verdicts on the constitutional ground of excessiveness without giving the plaintiff the alternative option of a new trial. See Developments in the Law-The Paths of Civil Litigation-Problems and Proposals in Punitive Damages Reform, 113 HARV. L. REV. 1783, 1790 n.52 (2000); Colleen P. Murphy, Judgment as a Matter of Law on Punitive Damages, 75 TuL. L. REV. 459, 476-77 (2000).

${ }^{27}$ See Colleen P. Murphy, Judicial Assessment of Legal Remedies, 94 Nw. U. L. REV. 153, 189 (1999).

28 See Baldus et al., supra note 16, at 1132-34.

${ }^{29}$ See, e.g., Cahill v. TIG Premier Ins. Co., 47 F. Supp. 2d 87, 89 (D. Mass. 1999); Murphy, supra note 26, at 476. 
judge decides that the award is excessive, again using the judge's own experiences or similar cases, the judge determines the maximum amount that a reasonable jury could have found and, as an alternative to the plaintiff trying the case again, reduces the jury's verdict to this maximum amount. ${ }^{31}$ Various criticisms have been made regarding this methodology, including that one judge cannot better determine the damages than a group of jurors. ${ }^{32}$ Additionally, criticisms are advanced that in determining the maximum reasonable verdict, judges compare damages in cases which are in fact dissimilar, and that the set of cases is incomplete because it includes only those cases in which verdicts are challenged and reported. ${ }^{33}$ The criticism developed in this article is that this

30 See Baldus et al., supra note 16 , at $1134-40$. In deciding the motion, a judge may weigh the evidence and credibility of the witnesses, but must have more justification for his decision to grant a new trial or altematively a remittitur than he would have to come to a different conclusion than the jury. See, e.g., Halbasch v. Med-Data, Inc., 192 F.R.D. 641,643 (D. Ore. 2000) (quoting Roy v. Volkswagen of Am., Inc., 896 F.2d 1174, 1176 (9th Cir. 1990)). A motion for a new trial contrasts with a motion for judgment as a matter of law. A judge may grant a motion for a new trial under Rule 59 "even if there is substantial evidence to support the jury's verdict," Caruolo v. John Crane, Inc., 226 F.3d 46, 54 (2d Cir. 2000) (citation and internal quotation marks omitted), and a trial judge considering a motion for a new trial may "weigh the evidence himself and need not view it in the light most favorable to the verdict winner." Densberger v. United Techs. Corp., 125 F. Supp. 2d 585, 597 (D. Conn. 2000) (quoting United States v. Landau, 155 F.3d 93, 104 (2d Cir. 1998) (internal quotation omitted)), aff'd, 297 F.3d 66 (2d Cir. 2002).

${ }^{31}$ See Baldus et al., supra note 16, at 1132-40; Albert D. Brault \& John A. Lynch, Jr., The Motion for a New Trial and Its Constitutional Tension, 28 U. BALT. L. REV. 1, 94 (1998). Defendant's counsel may suggest the amount of the remittitur. See Baldus et al., supra note 16, at 1119 n.17. A minority of courts have decided that the verdict should be reduced to the minimum that a jury could reasonably find. See Robert Billet Promotions, Inc. v. IMI Comelius, Inc., No. CIV.A.95-1376, 1998 WL 721081, at *15 (E.D. Pa. Oct. 14, 1998) (mentioning both standards). Such a standard may be less problematic constitutionally for the plaintiff under the Seventh Amendment.

32 It may be impossible to determine the accuracy of jury verdicts. See, e.g., ELLEN SWARD, THE DECLINE OF THE CIVIL JURY 216 (2001). Accuracy has been tested by comparing judges' verdicts with juries' verdicts but there may be no reason to believe that the judges are right. See id. When judges' and juries' verdicts have been studied there have been different results. Some studies have found remarkable similarity and other studies have found significant differences. Compare Theodore Eisenberg et al., Juries, Judges, and Punitive Damages: An Empirical Study, 87 CORNELL L. REV. 743 (2002) (finding significant similarity between decisions by judges and juries to award punitive damages), with Reid Hastie \& W. Kip Viscusi, What Juries Can't Do Well: The Jury's Performance as a Risk Manager, 40 ARIZ. L. REV. 901 , 916 (1998) (providing empirical results that judges are less likely to impose punitive damages and that greater use of judges would improve judicial decisions), and W. Kip Viscusi, Jurors, Judges, and the Mistreatment of Risk by the Courts, 30 J. LEGAL STUD. 107, 134-36 (2001) (same).

33 See Baldus et al., supra note 16, at 1173; J. Patrick Elsevier, Note, Out-of-Line: Federal Courts Using Comparability to Review Damage Awards, 33 GA. L. REV. 243 (1998); see also 
already subjective practice of remittitur effectively eliminates the plaintiff's right to a jury trial on damages.

\section{B. The Effect of Remittitur on the Right to a Jury Trial}

In the context of remittitur, the Supreme Court has long recognized the importance of the plaintiff's Seventh Amendment right to a jury trial. The Court has specifically stated that "a court has no authority, upon a motion for a new trial, 'according to its own estimate of the amount of damages which the plaintiff ought to have recovered, to enter an absolute judgment for any other sum than that assessed by the jury." "34 To comport with the Seventh Amendment, the plaintiff must be given the option to take a new trial as an alternative to the remittitur. ${ }^{35}$ Although the plaintiff is presented with the option of a new trial, essentially there is no such choice.

To explore the argument that remittitur effectively eliminates the plaintiff's right to a jury trial on damages, ${ }^{36}$ the perspective of the plaintiff must be examined at the point in the litigation when the judge grants the new trial for excessive damages or alternative remittitur. ${ }^{37}$ When a judge grants the motion, a jury has found the defendant liable under one or more causes of action. Moreover, the jury has found that the defendant should pay a certain amount of damages to compensate the plaintiff for the injury that she caused him. The findings come after the parties presented admissible evidence at a trial. Upon the findings for the plaintiff, the defendant likely moved for judgment as a matter of law and if so, was defeated on that motion. The defendant may have also moved for a new trial on the ground that the evidence was tainted in some way and if so, was defeated on that motion. The plaintiff is in the position of having presented legally admissible evidence to a jury which resulted in a liability finding that is legally sustainable.

When a judge grants the motion, she decides, based on her experience or a review of reported cases, that the evidence does not support the damages to the

cases cited infra app. A (referencing challenged and reported verdicts in making remittitur determination).

${ }^{34}$ Hetzel v. Prince William County, 523 U.S. 208, 211 (1998) (quoting Kennon v. Gilmer, 131 U.S. 22, $29(1889))$.

${ }^{35}$ See id. at 211 .

36 While the plaintiff's right to a jury trial on liability has been preserved by no interference with the liability finding, a remittitur effectively eliminates the plaintiff's right to a jury trial on damages. $C f$. infra note 257 (regarding the issues on which a judge can order a new trial upon the plaintiff's rejection of the remittitur).

${ }^{37}$ Of course, the plaintiff could move for a remittitur if defendant prevailed on a counterclaim. For simplicity, throughout this article, the person or entity subject to remittitur is referred to as the plaintiff and the person or entity who moves for remittitur is referred to as the defendant. 
extent awarded by the jury. The judge then decides the maximum amount that $\mathrm{d}$ : jury could have awarded under the facts presented. When the judge renders this i decision, it is well-established that the plaintiff cannot appeal the decision: immediately because the decision is not a final judgment. ${ }^{38}$ Instead the plaintiff. must take the new trial or the remittitur. If the plaintiff takes the remittitur, the : plaintiff cannot appeal. ${ }^{39}$ By accepting a remittitur, the plaintiff loses the right to appeal that issue, and also may lose the right to appeal the court's decision to : overturn as a matter of law a different damages award based on the same cause of action $^{40}$ or any other issues related to the cause of action pertaining to the remittitur. ${ }^{41}$

As unappealing as the remittitur may be to the plaintiff, a new trial appears to be a worse option for the plaintiff. If the plaintiff takes the new trial, in the second trial the plaintiff will present the same evidence as presented in the first because presumably the plaintiff would have put on his best case in the first trial. If the jury finds for the plaintiff and awards more damages than the remitted amount, ${ }^{42}$ there is every reason for the plaintiff to believe that the judge will reduce the damages again, because she is the same judge who previously determined the remitted amount was the maximum award under the facts. ${ }^{43}$ The plaintiff must be

38 See Donovan v. Penn Shipping Co., 429 U.S. 648, 650 (1977); Anderson v. Roberson, 249 F.3d 539, 542 (6th Cir. 2001) (stating that plaintiff cannot appeal decision ordering remittitur or alternatively new trial, nor appeal a remittitur accepted under protest; plaintiff can appeal only after proceeding through new trial); Wagner, supra note 16, at 647; Sann, Remittitur Practice, supra note 16, at 311-12, 321-25; see also Murphy, supra note 26, at 47879 (stating that plaintiffs may be better off if courts could order remittitur as a matter of law because then they could immediately appeal). But see Wagner, supra note 16, at 657-58 (arguing that plaintiffs should be permitted to appeal remittiturs directly or at least on crossappeals).

${ }^{39}$ See, e.g., Anderson, 249 F.3d at 542 n.2.

40 See Sulzer Carbomedics, Inc. v. Or. Cardio-Devices, Inc., 257 F.3d 449, 460-61 (5th Cir. 2001). But see Lanier v. Sallas, 777 F.2d 321, 325 (5th Cir. 1985) (stating that the plaintiff can accept remittitur on damages with respect to one cause of action and still appeal with respect to another cause of action).

41 See Utah Foam Prods. Co. v. Upjohn Co., 154 F.3d 1212, 1215-16 (10th Cir. 1998) (stating that the plaintiff cannot appeal denial of prejudgment interest and other issues related to cause of action that was subject to remittitur order).

42 Depending upon which issues the judge orders a new trial, the second jury could find against plaintiff on liability, it could find for less than the amount that the judge awarded; or it could find for the same amount or more. See infra note 257. As one judge put it, "[h]e may demand a new trial, and take his chances with a second jury." Sorenson v. Chi. Cent. \& Pac. R.R. Co., No. 89-C-4405, 1991 WL 53783, at *2 (N.D. Ill. Apr. 5, 1991).

43 It does not seem appropriate for a judge to reduce a verdict after a second jury has found the same amount of damages or less than the first jury found. See 11 WRIGHT ET AL., supra note 25, $\S 2815$, at 169 n.19. For example, in Page v. Trustees of Sandhills Community College, No. 3:96CV00358, 1999 WL 1937475 (M.D.N.C. Aug. 31, 1999), the court had granted a new trial when the plaintiff would not accept a remittitur to $\$ 40,000$ from a $\$ 446,000$ compensatory 
able to presume rational decision-making. That is, when the judge states the maximum amount that a reasonable jury could find, a judge would reduce a subsequent verdict greater than the remitted award. If that is not the case, then indeed the previous amount was not the maximum amount that a reasonable jury could find or a reasonableness determination was not even possible.

- After the second trial, now is the first time that the plaintiff may appeal the original decision to order a new trial. ${ }^{44}$ After this wait, the review by the appellate court is limited to abuse of discretion, ${ }^{45}$ and plaintiffs have found the abuse of discretion standard difficult to overcome. ${ }^{46}$

In the meantime, before the case has reached the appellate court, the plaintiff is likely to have incurred significant expenses in costs and attorneys' fees. ${ }^{47}$

damages award. See id. at *2. Upon the new trial, the court declined to remit a $\$ 200,000$ compensatory damages award. See id. Although a judge may decide not to remit a verdict after a second trial, the plaintiff is unlikely to take the chance of retrying the case after the judge has declared the maximum amount of damages that a reasonable jury could find. As a result the plaintiff will take the remittitur or, take the new trial to induce a settlement greater than the remittitur or "attempt the daunting task" to present the evidence such that in the second trial the judge is convinced that greater than the remitted amount is warranted. See Murphy, supra note 26 , at 464 .

44 Additionally, the defendant has the right to appeal the decision of the judge not to remit or order a new trial, or to appeal the decision of the judge to remit to a larger award than the defendant had requested. See 11 WRIGHT ET AL., supra note 25 , 2820 . The appellate court may affirm a grant or denial of remittitur or reverse a grant or denial of remittitur. See Gasperini v. Ctr. for Humanities, Inc., 518 U.S. 415, 434-35 (1996) (holding expressly for the first time that under the Seventh Amendment it is permissible to review for abuse of discretion the denial of a motion for a new trial on excessiveness grounds); Baldus et al., supra note 16, at 1135 (citing Martell v. Boardwalk Enters., 748 F.2d 740 (2d Cir. 1984)); Wagner, supra note 16, at 647. An appellate court may reinstate the original jury verdict after a new trial. See, e.g., Taylor v. Wash. Terminal Co., 409 F.2d 145, 149 (D.C. Cir. 1969). However, appellate courts often reduce awards not reduced by trial judges. See Baldus et al., supra note 16, at 1119 . While appellate courts can order remittitur, the plaintiff must be given the option of a new trial. See Eric Schnapper, Judges Against Juries-Appellate Review of Federal Civil Jury Verdicts, 1989 WIS. L. REV. 237, 344-47.

45 See, e.g., Gasperini, 518 U.S. at 434-35.

46 See Sann, Remittitur Practice, supra note 16, at 312-13. Irene Sann makes the interesting point that while an appellate court will find no abuse of discretion for a significant reduction in the jury's verdict, the same court upon a second trial will find no abuse of discretion when the trial court refused a new trial for a low verdict by the second jury. See id. at $312 \&$ n.87 (citing case examples). In contrast, defendants have been quite successful in overcoming the abuse of discretion standard in obtaining reversals in fifty percent of trial courts' denials of new trial motions for excessiveness. See Schnapper, supra note 44, at 248 (stating that appellate courts often apply the de novo standard, not abuse of discretion, in reviewing motions for new trial and/or for remittitur). All types of cases are reversed at approximately the same fifty percent rate. See id. at 249, 322-23.

47 See Wagner, supra note 16, at 647 (stating that the plaintiff must retry case, subjecting himself to expense and delay before he may appeal unfavorable remittitur decision); Sann, 
Given this predicament, there is little reason for the plaintiff to take the new:trial; if rationality is to be presumed, ${ }^{48}$ the plaintiff will not survive another motion for a new trial or alternatively, remittitur if a jury awards greater than the remitted amount, an appeal is highly likely to be unsuccessful and significant expenses likely would be incurred to go down this path. As a result, the plaintiff will take the remittitur or settle (based on the judge-determined damages), ${ }^{49}$ because the new trial is not a real choice. Additionally, because the judge may have reduced other jury verdicts, a plaintiff may settle a case before trial to prevent a similar result in his case. This seems far from the result intended by the Seventh Amendment.

A case study of remittitur in the federal district courts over a ten-year period confirms that remittitur effectively eliminates the plaintiff's Seventh Amendment right to a jury trial on damages. ${ }^{50}$ Using Westlaw, published and unpublished cases $^{51}$ were searched in the years 1991 through 2000,52 for the word "remittitur," the term of art in these types of cases. ${ }^{53}$ Because this study is concerned with

Remittitur Practice, supra note 16, at 312-13. Wagner proposes several ways to mitigate the coercive effect of remittitur on plaintiffs including: (1) the adoption of a uniform standard for determining excessiveness; (2) permitting a new trial on just damages when only damages were affected by prejudice or passion of the jury, (3) requiring the standard to determine the remitted amount not to be the lowest amount a jury would reasonably award; (4) limiting remittitur to liquidated damages, which rely on legal formulas; and (5) limiting appellate remittiturs. See Wagner, supra note 16, at 649-54; cf. Roger W. Kirst, Judicial Control of Punitive Damage Verdicts: A Seventh Amendment Perspective, 48 SMU L. REV. 63, 82 (1994) (stating that although "expense and risk of a second trial pushes many plaintiffs to agree to the remittitur," a "judge's power is limited because a plaintiff can reject the judge's calculation of the excessive portion and obtain a new trial from a second jury").

If a plaintiff does not accept the remittitur, attomeys' fees may be in jeopardy. See, e.g., Olabode v. Hecht, Inc., No. CIV.A.95-6221, 1997 WL 805187, at *14 (E.D. Pa. Dec. 30, 1997) ("Plaintiff's motion for attomey fees is DENIED without prejudice to its renewal if plaintiff accepts the remittitur.").

48 See supra text accompanying notes $42-44$.

${ }^{49}$ Cf. Michelle Cucuzza, Evaluating Emotional Distress Damage Awards to Promote Settlement of Employment Discrimination Claims in the Second Circuit, 65 BROOK. L. REV. 393 (1999) (arguing that lawyers should use remittitur decisions to settle their cases before trial).

50 See app. A. While appellate courts can remit damages awards, see Wagner, supra note 16 , at $639 \&$ n.1, this study was limited to remittitur by federal district courts.

51 See, e.g., Peter Siegelman \& John J. Donohue III, Studying the Iceberg from Its Tip: A Comparison of Published and Unpublished Employment Discrimination Cases, 24 LAW \& SOC'Y REV. 1133 (1990) (stating that there may be significant differences between unpublished and published decisions such that both should be reviewed).

52 This ten-year period of time was used for the purpose of surveying the phenomenon of remittitur over a significant time period.

53 The original search was cross-referenced against a search for the West key number for remittitur (170 AK 2377 (formerly $106 \mathrm{~K} \mathrm{353))}$ and dates from 1991 through 2000 in the 
what occurs after a judge grants a new trial for excessive damages, or altematively, a remittitur, cases in which judges denied a remittitur were eliminated. Cases in which judges remitted damages pursuant to a statutory cap also were eliminated. 54

Information on docket sheets, information provided by attorneys, and information from appellate decisions in these cases were used to determine whether the plaintiff accepted the remittitur, settled the case, or took the new trial.

federal district court database. This search confirmed that there were no additional relevant cases.

Westlaw was used because it is the best available research tool for this type of research. Empirical research has previously been conducted using Westlaw. See, e.g., Howard M. Erichson, Interjurisdictional Preclusion, 96 MICH. L. REV. 945, 1008-13 \& n.316 (1998); David Sherwyn et al., Don't Train Your Employees and Cancel Your "1-800" Harassment Hotline: An Empirical Examination and Correction of the Flaws in the Affirmative Defense to Sexual Harassment Charges, 69 FordHAM L. REV. 1265, 1275-76 (2001); Michael E. Solimine, The Quiet Revolution in Personal Jurisdiction, 73 TUL. L. REV. 1, 24 \& n.139 (1998); Ian Ayres \& Peter Siegelman, The Q-Word as Red Herring: Why Disparate Impact Liability Does Not Induce Hiring Quotas, 74 TEX. L. REV. 1487, 1494 n.27 (1996).

I considered the use of Pacer, a government database of docket information, and Casestream, a private database that catalogs information from Pacer, for this research. I concluded, however, that neither would be the best available research tools to search the federal district court cases. Both Pacer and Casestream do not include the district courts of Alaska, the Virgin Islands, the Western District of Wisconsin, Guam, Nevada, and the Northern Mariana Islands, some of which have cases on Westlaw that were used in the study. Both also are more limited than Westlaw in the time period covered because they contain cases that date back only to the early 1990s when Pacer was created. Additionally, while Casestream, like Westlaw, can be searched for key words, Pacer cannot.

54 This article does not take a position on the constitutionality of statutory caps on damages. Cf. Gasperini v. Ctr. for Humanities, Inc., 518 U.S. 415, 429 n.9 (1996) (discussing courts of appeals' decisions on the constitutionality of statutory caps). The analysis in this article is relevant regardless of the constitutionality or unconstitutionality of caps. If statutory caps are constitutional, in cases where there are no such caps, the analysis remains relevant. If statutory caps are unconstitutional, the analysis remains relevant in all cases, with caps or without. It may be that the reductions in the study do not reflect the full extent to which judges would reduce verdicts in various cases in the absence of statutory caps. For example, because Title VII of the Civil Rights Act of 1964 imposes damages caps on discrimination cases, in the absence of such caps, judges possibly would reduce more verdicts as excessive. See 42 U.S.C. $\S \S 2000 \mathrm{e}-1$ to $2000 \mathrm{e}-17$ (1994 \& Supp. V 1999); see, e.g., Dobrich v. Gen. Dynamics Corp., 106 F. Supp. 2d 386, 396 (D. Conn. 2000).

Despite the fact that a judge must give the option of a new trial to the plaintiff as an alternative to a remittitur, in some cases, judges have reduced verdicts without giving the option of a new trial. See, e.g., Bennett v. Smith, No. 96-C-2422, 2000 WL 1849029, at *9 (N.D. Ill. Dec. 18, 2000); Lafate v. Chase Manhattan Bank, 123 F. Supp. 2d 773, 790 (D. Del. 2000). The data in this study show remittitur without the option for a new trial was granted in 16 of the 184 cases, of which $25 \%$ were civil rights cases. These cases were excluded from the study because the plaintiff was not given the option to take a new trial. While not included in the study, the cases are designated in appendix A as "No Option" for informational purposes. 
The cases were further reviewed for the types of damages that the courts reduced and the corresponding causes of action. The types of damages include, for example: backpay, emotional distress, past and future pain and suffering, past medical expenses, punitives, ${ }^{55}$ and wrongful profits. The causes of action include, for example: breach of contract, defamation, employment discrimination, employment retaliation, Fair Credit Reporting Act, fraud, personal injury, products liability, $\S 1983$, tortious interference with contract, and trademark infringement.

The study of remittitur demonstrates that plaintiffs faced with a new trial or alternatively, a remittitur, indeed almost invariably choose the remittitur. Of the 168 federal district court cases reported on Westlaw in which a judge granted a remittitur as an altemative to a new trial, ${ }^{56}$ plaintiffs accepted the remittitur in $71 \%$ or 119 of the cases. If the plaintiff did not accept the remittitur, the plaintiff was highly likely to settle the case. Settlement occurred in $27 \%$ or 46 of the cases. ${ }^{57}$ Thus, the plaintiff took the remittitur or settled in $98 \%$ of the cases. In only $2 \%$ or three of the cases did the plaintiff take the new trial. ${ }^{58}$

55 Note that the study includes remittiturs of punitive damages only for nonconstitutional excessiveness. See Adam M. Gershowitz, Note, The Supreme Court's Backwards Proportionality Jurisprudence: Comparing Judicial Review of Excessive Criminal Punishments and Excessive Punitive Damages Awards, 86 VA. L. REV. 1249, 1287 (2000). While the Supreme Court has stated punitive damages are not facts and thus are not subject to the reexamination clause in the Seventh Amendment, punitive damages remain relevant to the analysis in this article. See Cooper Indus., Inc. v. Leatherman Tool Group, Inc., 532 U.S. 424, 432, 437 (2001). First, all of the cases in the study were decided before the Cooper Industries decision and thus punitive damages in those cases were arguably subject to the re-examination clause. Second, how the plaintiff reacted in those cases to the grant of the new trial and alternatively, the remittitur of the punitive damages by either taking the remittitur, settling the case, or taking the new trial, contributes to the analysis on whether the new trial is a real option for the plaintiff. For comparison purposes, the data are also calculated excluding the cases that involve solely the remittitur of punitive damages. See infra note 61. In any event, Cooper Industries was decided incorrectly. It is not true, contrary to the Court's decision, that the type of damages now available under the nomenclature "punitive damages" did not exist at English common law. Juries determined punitive damages at English common law in the 1791 time period. See infra notes 180-249 and accompanying text. There is no indication that courts treated these types of damages differently than other types of damages, thereby justifying the classification of punitive damages as "not facts." See id. Thus to comport with the Seventh Amendment, juries should determine those damages and review of such damages should also comport with the Seventh Amendment. See James Oldham, Determining Damages: The Seventh Amendment, the Writ of Inquiry, and Punitive Awards (Jan. 2003) (unpublished manuscript, on file with author).

56 See supra notes 54-55 (setting forth the cases that were excluded from the data).

57 If the plaintiff initially told the court that he wanted a new trial but he did not in fact retry the case, if the case settled, this was counted as a settled case.

58 In the small number of cases in which the plaintiff took the new trial, it appears that the plaintiffs took the new trial because the judge reduced the verdict so greatly that there was effectively nothing to lose by taking the new trial. See Lightfoot v. Union Carbide Corp., No. 92 
The findings regarding the effect of remittitur on the right to a jury trial are more significant when the types of damages that judges chose to remit are examined. The study demonstrates that judges granted new trials or altematively, remittitur mostly in cases with damages not calculable according to any formula. Thus, in most of the cases remitted, judges did not remit with certainty, but rather, substituted their interpretation of the evidence of uncertain damages suffered by the plaintiff for those of the jury. Specifically, of the 168 cases in which judges granted new trials for excessive damages or alternatively a remittitur, 68\% (115 cases) involved uncertain damages, ${ }^{59}$ and of these cases, the plaintiff accepted the remittitur or settled in $98 \%$ (113) of the cases. Finally, emotional distress damages were remitted in many of these cases. ${ }^{60}$ Such damages were remitted in $32 \%$ (53) of the 168 total number of cases. Of these cases, the plaintiff accepted the remittitur (74\%) or settled $(26 \%)$ in $100 \%$ of the cases.

A further look at the cases shows that judges use remittitur in many civil rights cases (employment discrimination, employment retaliation, Eighth Amendment, excessive force, Fair Housing Act, Fourteenth Amendment, $\S 1983$, and unwarranted arrest). Of the 168 remitted cases, $42 \%$ (71) were civil rights cases, 58 of which involved uncertain damages. Of the 71 civil rights cases reduced, the plaintiff accepted the remittitur (66\%) or settled $(31 \%)$ in $97 \%$ of the cases. $^{61}$

CIV. 6411, 1997 WL 543076, at *1 (S.D.N.Y. Sept. 4, 1997) (reducing verdict from $\$ 750,000$ to $\$ 75,000$ ); Fleet Nat'l Bank v. Anchor Media Television Inc., 831 F. Supp. 16, 45 (D.R.I. 1993) (reducing verdict from \$1 million to \$0); Kirsch v. Fleet St., Ltd., No. 92 CIV. 932, 1996 WL 396149, at *3-5 (S.D.N.Y. July 15,1996 ) (reducing verdict from $\$ 265,000$ to $\$ 116,374$ ).

59 As set forth in Part III.B.3, English common law courts would not grant new trials for excessive damages in cases involving uncertain damages, for example, in malicious prosecution and false imprisonment cases. It is not possible to directly compare the common law cases involving certain and uncertain damages to the federal cases here, because the names of and/or the types of damages awarded then and now were not always exactly the same. However, the data in the study are analyzed by categorizing cases involving certain versus uncertain damages such that any possible case involving only certain damages is categorized as certain. Thus, the only criticism of these figures could be that the uncertain number could be larger than set forth above. The following types of damages, for example, were categorized as certain: salary, wrongful profits, medical expenses, front pay, rent compensation, benefits, economic damages, lost pension, future lost earnings, and consequential damages. The following types of damages, for example, were categorized as uncertain: emotional distress, pain and suffering, punitives, lost anticipated profits, mental harm, and loss of life activity.

${ }^{60} C f$. Cucuzza, supra note 49 (describing the remittitur of emotional distress cases in the Second Circuit).

${ }^{61}$ One hundred fifty-one of the 168 cases involved the remission of some category of damages other than punitive damages. Plaintiff accepted (109 or $72 \%$ ) or settled (40 or $27 \%$ ) in $99 \%$ of these cases and took the new trial in 1\% (2) of those cases. Of those 151 cases, $65 \%$ (98) involved uncertain damages and of these cases, the plaintiff accepted the remittitur or settled in $99 \%$ (97) of the cases and took the new trial in 1\% (1) of those cases. Emotional distress damages were remitted in $35 \%$ (53) of the 151 cases. Of these cases, the plaintiff 
The current effect of remittitur on civil rights cases is actually skewed by the first few years of the data. The Civil Rights Act of 1991, which gave plaintiffs the right to uncertain damages (compensatory and punitive damages) and the right to a jury trial in employment discrimination cases, became effective only in 1991 and did not apply to cases pending at the time of the Act's enactment. ${ }^{62}$ Thus, in the last five years of the data (from 1996 to 2000), the data appear to show an even greater effect of remittitur on plaintiffs in civil rights cases. Sixty-three percent (55) of the 88 cases reduced from 1996 to 2000 were civil rights cases. ${ }^{63}$ Of the 55 civil rights cases reduced, the plaintiff accepted the remittitur ( 38 cases) or settled (16 cases) in $98 \%$ of the cases. In comparison, only $20 \%$ (16) of the 80 cases reduced from 1991 to 1995 were civil rights cases. ${ }^{64}$

The case study demonstrates that the new trial, the alternative "option" to the plaintiff to remittitur is, in fact, illusory. When the judge announces the maximum amount that a reasonable jury could award, the judge effectively announces that the plaintiff has one choice, not two-accept the remittitur. Any new trial with the same evidence will result in at most the judge-deemed reasonable remitted verdict. Thus, the plaintiff effectively has no choice to retry the case and will accept the remittitur or settle. The study demonstrates this hypothesis. Plaintiffs take the remittitur or settle in $98 \%$ of the cases. Moreover, the study shows that judges use this practice to reduce uncertain damages, including in civil rights cases.

accepted the remittitur (39) or settled (14) in 100\% of the cases. Forty-two percent (63) of the 151 total cases were civil rights cases, 50 of which involved uncertain damages. Of the 63 civil rights cases reduced, the plaintiff accepted the remittitur (41) or settled (20) in $97 \%$ of the cases and took the new trial in 3\% (2) of those cases.

62 See Landgraf v. USI Film Prods., 511 U.S. 244 (1994).

63 Moreover, from 1996 through 2000 , of the cases in which judges remitted emotional distress damages, $85 \%$ of the cases were civil rights cases.

${ }^{64}$ Note with respect to the effectiveness of appeals in civil rights cases, Eric Schnapper studied the reversal rates of jury verdicts by the appellate courts. See Schnapper, supra note 44, at 237-357. He found that employment discrimination cases had a higher rate of reversal than other types of cases, a finding he found surprising. See id. at 249-50. He argued because employment discrimination cases are less complicated than many other cases and greatly turn on assessments of witness credibility, reversals should be rare. See id.; see also Ruth Colker, Winning and Losing Under the Americans with Disabilities Act, 62 OHIO ST. L.J. 239 (2001) (stating that appellate courts favor defendants in appeals under Americans with Disabilities Act). In Eisenberg and Schwab's recent study, they found appellate courts reversed a disproportionate number of employment discrimination cases won by the plaintiffs in comparison to cases won by the defendants. See Theodore Eisenberg \& Stewart J. Schwab, Double Standard on Appeal: An Empirical Analysis of Employment Discrimination Cases in the U.S. Courts of Appeals (July 16, 2001) (report for Mehri, Malkin \& Ross, PLLC, and Cochran, Cherry, Givens \& Smith, PC), available at http://www.naacpfstf.org/ doublestandard.pdf (last visited May 24, 2003). 


\section{JURISPRUDENCE RELEVANT TO REMITTITUR}

The starting place to understand the current constitutional footing of remittitur is the Supreme Court's 1935 decision in Dimick v. Schiedt. ${ }^{65}$ In the context of a discussion of additur and remittitur, Dimick stated that any reexamination of facts found by a jury should be only according to practices in existence at English common law in 1791. This begins the analysis of what principles should govern the constitutionality of remittitur. From the text of the Seventh Amendment and its jurisprudence, this section argues that the most appropriate analysis of the constitutionality of remittitur is a static interpretation of the common law: did remittitur exist under the 1791 English common law? Additionally, even if an interpretation of the common law as evolving is adopted, at minimum, such an evolving view must preserve the place of the jury as the fact-finder as the jury functioned at common law.

\section{A. The Constitutionality of Remittitur Under Dimick v. Schiedt}

In Dimick, the Supreme Court discussed the constitutionality of remittitur in the context of its decision that additur, the increase of a jury's verdict by a court, was unconstitutional. ${ }^{66}$ The jury had awarded the plaintiff $\$ 500$ for personal injuries resulting from defendant's negligence in operating his car. ${ }^{67}$ The plaintiff moved for a new trial on the ground that, inter alia, the jury rendered an inadequate verdict. ${ }^{68}$ The judge ordered a new trial on this ground unless defendant consented to an increase of the jury award to $\$ 1500.69$ Upon defendant's consent to the increase, the plaintiff appealed and argued that he should be permitted to try the case before another jury. ${ }^{70}$ The Court of Appeals reversed. ${ }^{71}$ Although it stated that remittitur was constitutional, the Court of Appeals held that additur was unconstitutional, in violation of the Seventh Amendment. ${ }^{72}$

Upon the Supreme Court's review of the case, the Court stated that to decide the constitutionality of additur under the Seventh Amendment "resort must be had to the appropriate rules of the common law established at the time of the adoption of that constitutional provision in 1791." 73 The Court examined the English

\footnotetext{
65293 U.S. 474 (1935).

66 See id.

${ }^{67}$ See id. at 475.

${ }^{68}$ See id.

${ }^{69}$ See id. at $475-76$.

${ }^{70}$ See id. at 476.

71 See Dimick, 293 U.S. at 476.

72 See id.

${ }^{73}$ See id.
} 
common law at the time of the adoption of the Seventh Amendment in 1791' to determine whether additur existed at that time. ${ }^{74}$ Pursuant to this review, the Court decided that additur was not an established practice in the English common law courts in $1791 . .^{75}$

The Court then considered the argument that because the federal courts currently employed remittitur, they should also employ the analogous practice of additur. ${ }^{76}$ To decide this question, the Court discussed the constitutionality of remittitur. ${ }^{77}$ Because the Court had never discussed the common law basis of remittitur previously, ${ }^{78}$ the Court reviewed some English cases and treatises dated prior to 1791 to determine what support existed for the practice at common law. ${ }^{79}$

\author{
74 See id. at 476-82. \\ 75 See id. at 482. \\ 76 See id. \\ 77 See Dimick, 293 U.S. at 477-85. \\ 78 See id. at 483-84 (reviewing Blunt v. Little, 3 F. Cas. 760 (C.C.D. Mass. 1822) (No.
} 1,578), N. Pac. R.R. Co. v. Herbert, 116 U.S. 642 (1886), and Ark. Valley Land \& Cattle Co. v. Mann, 130 U.S. 69, 73 (1889)). Dimick cites the following Supreme Court cases regarding remittitur: Northern Pacific Railroad Co., 116 U.S. at 646 (involving plaintiff's acceptance of court-ordered remittitur of $\$ 15,000$ as alternative to new trial in negligence case); Arkansas Valley Land \& Cattle Co., 130 U.S. at 72-76 (involving plaintiff accepting remittitur of $\$ 22,833.33$ as alternative to new trial in conversion case and stating remittitur does not deprive defendant of constitutional right to a jury trial); Kennon v. Gilmer, 131 U.S. 22, 29-30 (1889) (stating that the Seventh Amendment requires that a new trial must be offered as alternative to remittitur); Koenigsberger v. Richmond Silver Mining Co., 158 U.S. 41, 52-53 (1895) (holding that by accepting remittitur, plaintiff waived right to appeal and that the court could properly reduce verdict based on presented evidence without violating defendant's right to a jury trial); German Alliance Insurance Co. v. Hale, 219 U.S. 307, 312 (1911) (involving plaintiff's acceptance of remittitur from $\$ 5,198.93$ to $\$ 4112$ in insurance policy case); Gila Valley, Globe, \& North Railway Co. v. Hall, 232 U.S. 94, 98, 103-05 (1914) (involving plaintiff voluntarily remitting $\$ 5000$ of a $\$ 10,000$ jury verdict upon a motion for a new trial in negligence case); Clark v. Sidway, 142 U.S. 682, 684 (1892) (involving plaintiff's acceptance of remittitur from $\$ 6,700.75$ to $\$ 4000$ in case based on a warranty deed) (cited by the dissent in Dimick); Lewis $v$. Wilson, 151 U.S. 551, 554-55 (1894) (stating that plaintiff waived his right to obtain the full amount awarded by the jury by consenting to remittitur in open court) (cited by the dissent in Dimick); Tevis v. Ryan, 233 U.S. 273, 274-75, 290 (1914) (involving remittitur of \$64,564.63 by plaintiff in contracts case) (cited by the dissent in Dimick); and Union Pacific Railroad Co. v. Hadley, 246 U.S. 330, 333-34 (1918) (involving remittitur of verdict to $\$ 13,500$ from $\$ 25,000$ in negligence case) (cited by the dissent in Dimick).

79 See Dimick, 293 U.S. at 477-87. "Until ... Dimick ... there appears to have been no extended research into the practices and procedures of the English courts at the time the Seventh Amendment was adopted in 1791." Dagnello v. Long Island R.R. Co., 289 F.2d 797, 803 (2d Cir. 1961). Dimick cited the English cases of Brown v. Seymour, 95 Eng. Rep. 461 (1742); Burton v. Baynes, 94 Eng. Rep. 852 (1732); Beardmore v. Carrington, 95 Eng. Rep. 790 (1764); Belt v. Lawes, 12 Q.B.D. 356 (1884); Watt v. Watt, (1905) A.C. 115; and Lionel Barber \& Co. v. Deutsche Bank (Berlin) London Agency, (1919) A.C. 304, in addition to the following treatises: 2 Bacon's Abridgement (7th ed.); Sayer's Law of Damages (1770); Mayne's 
The Court did not, however, extensively research the common law..$^{80}$ Indeed it cited only one English case decided prior to the adoption of the Amendment that discussed the reduction of verdicts. ${ }^{81}$ In that case, the court had rejected any such power of courts to reduce verdicts. ${ }^{82}$ Despite this lack of authority for remittitur, the Supreme Court concluded that "there was some practice ... in respect of decreasing damages." 83 The Court also mentioned the federal courts' application of remittitur for over one hundred years since the 1822 lower court decision of Blint v. Little. ${ }^{84}$ Without citing any English cases in which courts actually applied remittitur and although this "practice ... ha[d] been condemned ... by every reasoned English decision, both before and after the adoption of the Federal Constitution," the Court suggested in dicta that courts in the future should not revisit the constitutionality of remittitur. ${ }^{85}$

The Court specified that it did not, however, decide the question of the constitutionality of remittitur in that case and acknowledged that "it ... may be that if the question of remittitur were now before us for the first time, it would be

Treatise on Damages (9th ed.); Brooke's New Cases, March's Translations; Blackstone's Commentaries; Story on the Constitution; Cooley's Constitutional Limitations (8th ed.); Tidd's Practice (cited by dissent in Dimick); and Sedgwick on Damages (6th ed.) (cited by dissent in Dimick). Bacon's Abridgement, Sayer's Law of Damages, Mayne's Treatise on Damages, Blackstone's Commentaries, and Tidd's Practice are analyzed infra Part III.B. Dimick also cited one state case that held a court could not alter a jury verdict other than by the grant of a new trial. See Dimick, 293 U.S. at 478 (citing McCoy v. Lemon, 45 S.C.L. (11 Rich.) 165 (Ct. App.1856)).

80 See Dimick, 293 U.S. at 477-85.

${ }^{81}$ See id. (citing Beardmore v. Carrington, discussed infra Part III.B).

82 See id.

${ }^{83} \mathrm{Id}$. at 482.

84 See id. at 482, 484-85. In Blunt v. Little, Justice Story found remittitur appropriate if plaintiff accepted it as an alternative to a new trial. Justice Story had not, however, analyzed the constitutionality of remittitur, nor cited cases in support of the constitutionality nor even the general propriety of granting remittitur. See 3 F. Cas. 760, 761-62 (C.C.D. Mass. 1822) (No. 1578); Sann, Remittitur Practice, supra note 16, at 301. Indeed Justice Story stated in "interfering with the verdict" he went "to the very limits of the law." 3 F. Cas. at 762. Blunt cited two English cases decided after the enactment of the Constitution that support only the grant of a new trial when damages are excessive. See id. at 767 (citing Chambers v. Caufield, 6 East 244, 102 Eng. Rep. 1280 (1805), and Hewlett v. Cruchley, 5 Taunt. 277, 128 Eng. Rep. 696 (1813)). Eight years after Blunt, in Parsons v. Bedford, 28 U.S. (3 Pet.) 433 (1830), Justice Story stated:

The only modes known to the common law to re-examine such facts, are the granting of a new trial by the court where the issue was tried, or to which the record was properly returnable; or the award of a venire facias de novo, by an appellate court, for some error of law which intervened in the proceedings.

Id. at 447-48; see also City of Lincoln v. Power, 151 U.S. 436, 438 (1894); Barney v. Schmeider, 76 U.S. (9 Wall.) 248, 251, 254 (1869).

85 See Dimick, 293 U.S. at 484-85. 
decided otherwise."86 It further declared that it would not extend the "doubtfal precedent" of remittitur to additur "by mere analogy" because it would "weaken or subvert what it conceive[d] to be a principle of the fundamental law of the land"- that is, the right to a jury trial. ${ }^{87}$

In refusing to hold additur constitutional, the Court stated:

The common law is not immutable, but flexible, and upon its own principles adapts itself to varying conditions. But here, we are dealing with a constitutional provision which has in effect adopted the rules of the common law, in respect of trial by jury, as these rules existed in 1791. To effectuate any change in these rules is not to deal with the common law, qua common law, but to alter the Constitution. 88

The common law in 1791 was the rule that, according to the Seventh Amendment, could not be altered. ${ }^{89}$

Although adhering to this mandate with respect to additur, the Court inexplicably ignored it with respect to its commentary on the constitutionality of remittitur. It cited no cases in which English courts employed remittitur and it explicitly stated that under the common law in 1791, "reasoned" English decisions rejected remittitur. ${ }^{90}$ Although there was no support for remittitur in the English common law in 1791, the Court stated that the constitutionality of remittitur should not be revisited in the future because of "some" unspecified English common law practice of remittitur and its use for over one hundred years in the federal courts. ${ }^{91}$

86 See id. at 484.

${ }^{87}$ See id. at $484-85$. The Court also went on to distinguish remittitur from additur with remittitur being merely a lopping off of the award the jury rendered, as opposed to additur, which is an addition of an amount that the jury never rendered. See id. at 485-87. The Court also mentioned that states had rendered decisions on the constitutionality of additur that went both ways and thus the decisions were not helpful to the Court's analysis. See id. at 488.

${ }^{88}$ Id. at 487 (citation omitted).

${ }^{89}$ See id.

90 See id. at 482-85.

91 See Dimick, 293 U.S. at 484-85. The irony of the Dimick decision is the fact that at English common law, courts did employ additur in cases of mayhem (although not the " "rule of practice" " in 1791, see Oldham, supra note 55), while courts never employed remittitur. See infra note 186; text accompanying notes 191-92; Part III.B. In mayhem cases, judges like juries could view the external injury (the maiming). See Oldham, supra note 55. Thus, they could determine whether the damages should be greater than the jury assessed. See id.

It is also noteworthy that Dimick focused on the defendant's right to a jury trial, in contrast to this article, which focuses on the plaintiff's right to a jury trial.

The dissent took the position that both remittitur and additur did not violate the Seventh Amendment. See id. at 488-98 (Stone, J., dissenting). Procedures unknown at common law could be constitutional as long as "the jury's function ha[d] not been curtailed." Id. at 492 (Stone, J., dissenting). In deciding that the jury's function was not curtailed, the dissent stated 
B. "[T] he Common Law" and the Re-examination Clause: 1791 English Practice Versus an Evolving Common Law

:

In Dimick, "the common law" in the Seventh Amendment was the English common law in 1791. The Court stated that to determine the constitutionality of additur (and it used the same analysis when it looked at remittitur), the Court must look at whether additur existed under the English common law in $1791 .{ }^{92}$ Supreme Court jurisprudence since Dimick has complicated this analysis. The Court has not always looked to the English common law in 1791 to determine whether a practice that re-examines facts found by a jury violates the Seventh Amendment. ${ }^{93}$ This section will examine the text of the Amendment, in addition to post-Dimick case law, for principles that should govern the Court's analysis of the issue of the constitutionality of remittitur under the re-examination clause today. Specifically, the text of the re-examination clause, in comparison to the rest of the Amendment and to the Constitution, arguably dictates a static reading of the clause such that the common law in 1791 should guide the analysis of what re-examination of facts determined by a jury is permitted. In Gasperini v. Center for Humanities, Inc., ${ }^{94}$ the Court's most recent significant case regarding the reexamination clause, the four dissenting Justices maintained the view that the common law was the English common law in 1791. Even if this static interpretation of the clause is rejected, however, in favor of an evolving interpretation as the majority in Gasperini did, in order to give meaning to the Seventh Amendment, a view of the common law as evolving must maintain the role of the jury as fact-finder, at minimum, as it functioned at English common law in 1791 .

\section{A Static 1791 English Common Law Reading of the Text of the Re-examination Clause}

The Seventh Amendment provides that "[i]n Suits at common law ... the right of trial by jury shall be preserved, and no fact tried by jury, shall be otherwise re-examined in any Court of the United States, than according to the

"[t]he authority of the court to determine whether the damages are excessive implies authority to determine when they are not of that character." Id. at 493-94 (Stone, J., dissenting).

92 See supra text accompanying notes 73-75.

93 See, e.g., Colleen P. Murphy, Integrating the Constitutional Authority of Civil and Criminal Juries, 61 GEO. WASH. L. REV. 723, 755 (1993) ("Reference to history ... is not the only approach the Court has employed in defining the constitutional authority of the civil jury. Rather than require strict adherence to pre-1791 procedures, the Supreme Court has focused frequently on the civil jury's functions.").

94 518 U.S. 415,433 (1996). 
rules of the common law." 95 The "common law" language in the first and secondi." clauses of the Seventh Amendment is unique in the Constitution..$^{96}$ What this: "common law" language means is unclear from the text of the Amendment and the records surrounding its adoption ${ }^{97}$ and as a result has been the subject of much research and debate. 98 "Common law" could refer to the practice of thel English common law courts, to the practice of the states, to the practice of the federal courts or to all of these..$^{99}$ Additionally, it could refer to those practices in 1791 when the Amendment was adopted or to the evolving process of the law: $100_{1}$, Also, while both the first clause and the second clause refer to the "common law!" the two clauses refer to the common law in different ways, the first clause stating" "[i]n Suits at common law" and the second clause stating "the rules of the common law." Thus, the meaning of "common law" could depend on which clause is relevant to the analysis. ${ }^{101}$

The constitutionality of the new trial for excessive damages and remittitur involves the second clause-the re-examination clause-of the Seventh Amendment. ${ }^{102}$ When a judge orders a new trial for excessive damages or alternatively a reduction of the damages rendered by a jury, the judge re-examines the facts - the damages-tried by the jury. ${ }^{103}$ According to the second clause in

95 U.S. CONST. amend. VII (emphasis added); see Parsons v. Bedford, 28 U.S. (3 Pet.) 433, 446-48 (1830). The Amendment has been interpreted to apply to both plaintiffs and defendants and interpreted to govern the right to a jury trial for federal claims, as well as state claims and diversity claims in federal court. See Galloway v. United States, 319 U.S. 372, 393 (1943); Margaret L. Moses, What the Jury Must Hear: The Supreme Court's Evolving Seventh Amendment Jurisprudence, 68 GEO. WASH. L. REV. 183, 185 (2000). While the Seventh Amendment has not been applied in state courts through the Due Process Clause of the Fourteenth Amendment, many states' constitutions also provide a right to a jury trial. See Jean R. Sternlight, Rethinking the Constitutionality of the Supreme Court's Preference for Binding Arbitration: A Fresh Assessment of Jury Trial, Separation of Powers, and Due Process Concerns, 72 TUL. L. REV. 1, 70 (1997).

${ }^{96}$ See Seminole Tribe of Fla. v. Florida, 517 U.S. 44, 164-65 \& n.59 (1996) (Souter, J., dissenting) (differentiating between the Seventh Amendment and the Eleventh Amendment, while both having common law influence, the former by its specific language "intended to adopt the common law").

${ }^{97}$ See Charles W. Wolfram, The Constitutional History of the Seventh Amendment, 57 MINN. L. REV. 639, 652 (1973) ("[T]he original understanding can be only imperfectly perceived today.").

${ }^{98}$ See infra notes $114-44$ and accompanying text.

${ }^{99}$ See Wolfram, supra note 97 , at 732-34.

100 See infra notes $114-44$ and accompanying text.

101 See infra text accompanying notes 114-42.

102 See Hetzel v. Prince William County, 523 U.S. 208, 210-11 (1998).

103 See Feltner v. Columbia Pictures Television, Inc., 523 U.S. 340, 355 (1998) (noting that as a general matter, juries decide damages); Hetzel v. Prince William County, 523 U.S. 208, 211 (1998) (stating that damages are facts determined by juries). But see Cooper Indus. v. 
the Seventh Amendment, this re-examination must be "according to the rules of the common law."

The plain meaning of the text of the two clauses of the Seventh Amendment indicates that any re-examination of facts must not interfere with the role of the jurry as determiner of the facts except according to the common law rules. ${ }^{104}$ The first clause generally requires a jury trial " $[i] n$ Suits at common law" and distinctly complements the second clause which limits re-examination of facts determined by a jury to be only "according to the rules of the common law."105 The first clause seeks to preserve or protect the right to a jury trial generally, while the second clause seeks to protect the right to a jury trial specifically by ensuring that where there is a jury trial that facts determined by juries are not reexamined, except according to the rules of the common law.

An "evolving" view of the first clause and a more static view of the second clause ensures protection of the jury trial right. This evolving view of the first clause is demonstrated by City of Monterey v. Del Monte Dunes at Monterey, Ltd. ${ }^{106}$ There, the Court recognized the right to a jury trial in $\S 1983$ cases, cases which did not exist at English common law in 1791.107 The Court reasoned that $\S 1983$ cases were similar in nature to tort cases which existed at English common law in 1791 and under which there was a right to a jury trial. ${ }^{108}$ This resulted in an expansion of the right to a jury trial beyond the causes of action which existed at common law. ${ }^{109}$ In contrast to this expansion of the right to a

Leatherman Tool Group, Inc., 532 U.S. 424 (2001) (determining that punitive damages are not facts).

104 The text of the Amendment becomes paramount because there is little evidence of the intention of the framers of the Seventh Amendment. See Colgrove v. Battin, 413 U.S. 149, 152-55 \& n.7 (1973) (citing Edith Guild Henderson, The Background of the Seventh Amendment, 80 HARV. L. REV. 289, 291 (1966)); $c f$. United States v. Menasche, 348 U.S. 528, 538-39 (1955) (quoting NLRB v. Jones \& Laughlin Steel Corp., 301 U.S. 1, 30 (1937)) (stating that in interpreting statutes, the meaning of every section must be preserved); Reiter $v$. Sonotone Corp., 442 U.S. 330, 339 (1979) (same).

105 U.S. CONST. amend. VII (emphasis added).

106526 U.S. 687 (1999); see also Curtis v. Loether, 415 U.S. 189 (1974) (finding a Seventh Amendment right to jury trial in case under Fair Housing Act, a cause of action that did not exist at common law); infra note 138.

107 See Del Monte Dunes, 526 U.S. 687.

108 See id. at 715.

${ }^{109}$ See id. at 718. In this case, a developer sought a jury trial for its claim under section 1983 that the City of Monterey had violated the Takings Clause by denying the developer the right to develop its property without compensating the developer. See id. at 693-94. Justices O'Connor, Souter, Ginsburg, and Breyer disagreed with the majority that the underlying takings claim (or inverse condemnation case) should be tried by a jury. They focused on the analogy between direct condemnation cases which were not tried by a jury at common law and indirect condemnation cases, which did not exist at common law. See id. at 733-34 (Souter, J., concurring in part and dissenting in part). The Justices reasoned that because direct condemnation cases were not tried by a jury, indirect condemnation cases also should not be 
jury trial, upon the expansion of the re-examination of jury findings beyond the re-examination that occurred at common law, the right to a jury trial may contract. For example, if a judge reduces outright damages found by a jury, a reexamination of facts not allowed at common law, ${ }^{110}$ the right to a jury trial contracts, because the judge's determination is substituted for the jury's. ${ }^{111}$

An additional argument for a static textual reading of the re-examination clause is that language similar to the clause - "according to the rules of the common law"-which by its plain language requires application according to particular "rules," is found nowhere else in the Constitution.112 Thus, to give meaning to the text of the clause in the context of the whole Constitution, the "common law" must affect what re-examination is permitted. Without giving such meaning to the clause, the clause would have no effect. Moreover, without being tied to some concrete practice, the legislature or courts can rewrite the rules on what facts the judge can re-examine at any given time. ${ }^{113}$

\section{Recent Supreme Court Jurisprudence Regarding the Static 1791 English Common Law Interpretation of the Re-examination Clause}

The text of the Seventh Amendment appears to dictate a static reading of the re-examination clause and the Supreme Court has recognized this static reading. In a number of decisions, the Supreme Court has interpreted "common law" in the re-examination clause to be static, tied to the English common law practice in

tried by a jury. See id. at 734-36. While the Justices believed that a right to a jury trial was improper for indirect condemnation cases, the reasoning was based on the analogy to direct condemnation cases, not because direct condemnation did not exist at common law. See id. Thus the dissenting Justices' opinion comports with an evolving view of the first clause.

110 See infra Part III.B.2.

111 One might argue that if the right to a jury expands, as it has into $\S 1983$ cases, the right to re-examine the facts determined by a jury should also expand. While a seemingly parallel argument, this does not take into account that any additional retrenchment on the jury's factfinding can effectively take away the right to a jury trial, as does remittitur. See supra Part I.B; infra Part III.D.

112 See U.S. CONST.

113 Cf. Stanton D. Krauss, Commentary on Akhil Reed Amar's "The Bill of Rights": Creation and Reconstruction: The Original Understanding of the Seventh Amendment Right to Jury Trial, 33 U. RICH. L. REV. 407, 451 (1998) ("What other (singular) set of common-law reexamination rules [other than the English common law rules] was there?"). But see George C. Christie, Judicial Review of Findings of Fact, 87 Nw. U. L. REV. 14, 15 (1992) (" "[R]ules of the common law' have always been in a state of evolution."); id. at 52 \& n.156 ("Given that the common law is always 'evolving' and that the Court itself is the final arbiter of what this evolving common law requires, it is no surprise that the Seventh Amendment has not been much of a hurdle."). 
1791.114 That interpretation appeared to change in Gasperini, the Court's most recent significant decision that involves the re-examination clause. ${ }^{115}$

In Gasperini, the Court examined whether appellate courts could properly review a trial judge's denial of a motion for a new trial for excessive damages. ${ }^{116}$ Although the practice was previously deemed unconstitutional because it did not exist at common law, the Court now decided that it was constitutional. 117

While in their dissents Justices Stevens and Scalia, joined by Chief Justice Rehnquist and Justice Thomas, explicitly recognized "the common law" in the Seventh Amendment as the English common law in 1791,118 the majority

114 See, e.g., Colgrove v. Battin, 413 U.S. 149, 152 n.6 (1973) (holding under the first clause of the Seventh Amendment that a six-member jury did not violate the Seventh Amendment, although there were twelve jurors at common law, and distinguishing the second clause of the Seventh Amendment, stating "reference to 'common law' contained in the second clause of the Seventh Amendment ... deals exclusively with the prohibition contained in that clause against the indirect impairment of the right of trial by jury through judicial reexamination of factfindings of a jury other than as permitted in 1791"); Balt. \& Carolina Line, Inc. v. Redman, 295 U.S. 654, 656-57 (1935) (stating that the first clause preserved jury trial "right which existed under the English common law when the Amendment was adopted" and through second clause "discloses a studied purpose to protect it from indirect impairment through possible enlargements of the power of reexamination existing under the common law"); Dimick, 293 U.S. at 476-77, 487; Capital Traction Co. v. Hof, 174 U.S. 1, 8 (1899) (stating the second clause refers to "the rules of the common law of England, and not the rules of that law as modified by local statute or usage in any of the States"); $c f$. United States v. Wonson, 28 F. Cas. 745, 750 (No. 16,750) (C.C.D. Mass. 1812) ("Beyond all question, the common law here alluded to is not the common law of any individual state, (for it probably differs in all), but it is the common law of England, the grand reservoir of all our jurisprudence." This is "obvious.").

115 See 518 U.S. at 461 (Scalia, J., dissenting) ("The footnote abandonment of our traditional view of the Reexamination Clause is a major step indeed."); Patrick Woolley, Mass Tort Litigation and the Seventh Amendment Reexamination Clause, 83 IOWA L. REV. 499, 505 (1998). But see Murphy, supra note 93, at 773 (stating that the Court has looked at jury functions and not only 1791 practices).

116518 U.S. 415 (1996). In Gasperini, a journalist sued after 300 slides regarding his work in Central America were lost by an organization to which he had loaned the slides. See id. at 419 . The jury awarded $\$ 450,000$, after an expert testified that each of the slides was worth $\$ 1500$. See id. at 420 . The district court denied the motion for a new trial for excessive damages. See id. The Second Circuit applied the New York law that states an award is excessive " 'if it deviates materially from what would be reasonable compensation.' " See id. (quoting N.Y. C.P.L.R. $§ 5501$ (c)). Looking at New York cases on damage awards in cases that involved slides, the Second Circuit decided that the damages were excessive and ordered a new trial unless Gasperini accepted a reduction to $\$ 100,000$. See id. at 420-21. The Supreme Court decided that the state law standard of " 'deviates materially" " applied in this diversity case, rather than the federal standard of shocks the judicial conscience. See id. at 426-31 (quoting N.Y. C.P.L.R. § 5501(c)).

117 See id. at 434-35 (citing Lincoln v. Power, 151 U.S. 436, 437-38 (1894)).

$118 \mathrm{See} 518$ U.S. at 451-52 (Scalia, J., dissenting); 518 U.S. at 443 (Stevens, J., dissenting). In his dissent joined by Chief Justice Rehnquist and Justice Thomas, Justice Scalia 
appeared to adopt some other approach. ${ }^{119}$ The majority specifically stated that the common law was not "fixed at 1791."' 20 In support of its position, the Court stated that the adoption of procedures by the federal courts that were unavailable at common law, such as new trials on only damages, judgment as a matter of law and issue preclusion absent mutuality of parties, demonstrated that the common law was not fixed.121 Accordingly, if the common law was not fixed, other. procedures, such as those at issue in this case-appellate review of the denial of the motion for a new trial for excessive damages - could be constitutional even if the procedure did not exist at common law. ${ }^{122}$

stated that appellate courts did not review facts at English common law in 1791. See 518 U.S. at 455-58 (Scalia, J., dissenting). Thus such review here was unconstitutional. See id. Justice Scalia also pointed out the "abuse-of-discretion" standard did not exist at common law. See id. at 460-61 (Scalia, J., dissenting).

Justice Stevens stated that if the reduction of damages could not be made as a matter of law, to comport with the Seventh Amendment, the practice must bear some relationship to the common law practice in England in 1791. See id. at 443-46 (Stevens, J., dissenting). Finding that the English en banc court, which considered motions for new trials, "was in essentially the same position as a modem court of appeals," Justice Stevens found appellate review constitutional under the Seventh Amendment. See id. at 444 (Stevens, J., dissenting). While Justice Stevens agreed with the majority that appellate review was constitutional, he disagreed that the case should be remanded to the district court. See id. at 439 (Stevens, J., dissenting). Instead he would have affirmed the Court of Appeals's decision to order a new trial if Gasperini did not take the remitted verdict of $\$ 100,000$. See id. at 439 (Stevens, J., dissenting).

119 See 518 U.S. at $432-36$.

120 Id. at 436 n. 20.

121 Id. at 436 \& n.20 (citing Gasoline Prods. Co. v. Champlin Ref. Co., 283 U.S. 494 (1931); FED. R. CIV. P. 50(b); Parklane Hosiery Co. v. Shore, 439 U.S. 322, 335-36 (1979)).

122 See id. at 432-39; see also Henderson, supra note 104, at 299-310. In support of the proposition that the Seventh Amendment is not "fixed at 1791," the Court also cited Colgrove v. Battin, 413 U.S. 149 (1973), which held that empanelling six jurors did not violate the Seventh Amendment although there were twelve jurors at common law. See 518 U.S at 436 n.20. This support is misplaced because unlike Colgrove, which concerned the first clause, Gasperini concemed the second clause. In Colgrove, the Court specifically distinguished "common law" in the second clause, calling it "irrelevant" to the case because the second clause prohibited the re-examination of fact-findings of a jury other than as permitted in 1791. See 413 U.S. at 152 n.6; supra note 114. Colgrove thus continued to recognize a special role for 1791 practice with respect to the re-examination clause.

The Court had also discussed the authority under the re-examination clause of the federal trial courts to grant new trials. See 518 U.S. at 432-33. The Court equated the constitutional authority of the federal courts to grant new trials with the statutory authority of the federal courts to grant new trials under Federal Rule of Civil Procedure 59(a). See id. at 432-33. Quoting Rule 59(a), the Court stated "the Reexamination Clause does not inhibit the authority of trial judges to grant new trials 'for any of the reasons for which new trials have heretofore been granted in actions at law in the courts of the United States.' "See id. at 433. The Court had, just above this quote, quoted the Seventh Amendment requiring that any "fact tried by a jury" be reexamined only "according to the rules of the common law." See id. at 432-33. The Seventh Amendment requirement of "according to the rules of the common law"and the Rule 
The common thread of the procedures discussed by the majority is that they all in fact preserve the function of the jury as the fact-finder as it functioned at English common law in 1791. Thus, the principle emerges that the common law may expand but not limit the jury's role as it existed in 1791. Partial new trials on damages, while unavailable at common law, protect the jury's original liability finding and thus the jury's function as fact-finder remains intact. ${ }^{123}$ Moreover, a jury still decides the damages upon the second trial as it did at English common law. ${ }^{124}$ Additionally, under judgment as a matter of law, if applied according to the principle, there is no re-examination of facts found by the jury because the only reasonable view of the facts requires one particular result under the specific law in the case. The jury could not have logically derived its conclusion from the law under which the jury was constrained. ${ }^{125}$ Finally, no re-examination of facts

59 requirement "for any of the reasons for which new trials have heretofore been granted in actions at law in the courts of the United States" are not necessarily the same. Congress could not by the promulgation of Rule 59 constitutionalize under the re-examination clause of the Seventh Amendment practices occurring in federal courts that are otherwise unconstitutional. Rather than Rule 59, the requirement for whether a practice comports with the re-examination clause is whether the practice is in accordance with the rules of the common law.

123 See Gasoline Prods. Co. v. Champlin Ref. Co., 283 U.S. 494, 497 (1931).

124 See id.

125 See Weisgram v. Marley Co., 528 U.S. 440, 452-57 (2000) (stating that appellate court can order judgment as a matter of law if evidence was improperly admitted and with the exclusion of that evidence, the verdict loser would be entitled to judgment based on the law and the remaining evidence); Neely v. Martin K. Eby Constr. Co., 386 U.S. 317, 319-20 (1967) (affirming court of appeals' reversal of trial court's denial of judgment as a matter of law, where there was insufficient evidence for a finding for the verdict winner, with instructions to trial court to dismiss case); Montgomery Ward \& Co. v. Duncan, 311 U.S. 243, 251 (1940) (differentiating judgment as a matter of law, which cannot be granted "unless, as matter of law, the opponent ... failed to make a case," from motions for a new trial which may involve the discretion of the judge regarding whether for example a verdict is excessive or alternatively may involve questions of law because of for example evidentiary errors); Balt. \& Carolina Line, Inc. v. Redman, 295 U.S. 654, 659 (1935) (stating that under a motion for judgment as a matter of law, "[w] hether the evidence was sufficient or otherwise [for a verdict for the plaintiff under the law] was a question of law to be resolved by the court" and distinguishing Slocum); Slocum v. N.Y. Life Ins. Co., 228 U.S. 364, 397-400 (1913) (ordering a new trial upon the appellate court's reversal of the trial court's denial of judgment notwithstanding the verdict); see also Fidelity \& Deposit Co. v. United States, 187 U.S. 315, 318-22 (1902) (finding constitutional a rule that permitted the court to grant the plaintiff judgment before trial because the defendant failed to raise a defense that if true would entitle it to judgment); Galloway v. United States, 319 U.S. 372, 389-96 (1943) (stating that directed verdict does not violate Seventh Amendment reexamination clause even though it did not exist at English common law because right to jury trial requires "jury be allowed to make [only] reasonable inferences from facts proven in evidence having a reasonable tendency to sustain them"); N.Y. Times Co. v. Sullivan, 376 U.S. 254, 285 n.26 (1964) (stating that the Seventh Amendment's "ban on re-examination of facts does not preclude us from determining whether governing rules of federal law have been properly applied to the facts"); Murphy, supra note 26, at 466-67 \& nn.34-35 (citing N.Y., 
tried by a jury occurs under issue preclusion absent mutuality of the parties. 126 Once a jury determines an issue, the determination is not revisited. ${ }^{127}$

As for the issue at hand in Gasperini-appellate review of the denial of a new trial motion for excessiveness--the majority attempted to distinguish this previously unconstitutional practice that was not permitted at common law ${ }^{128}$ by characterizing the review as a legal question of the upper limit of the damages available under the facts. ${ }^{129}$ This characterization is wrong. There is no upper limit of damages in a case in which the damages are uncertain (and where there is

Lake Erie \& W.R.R. Co. v. Estill, 147 U.S. 591, 619, 622 (1893) (denying interest awarded by jury because judge incorrectly instructed jury to assess interest); Ins. Co. v. Piaggio, 83 U.S. (16 Wall.) 378, 386-88 (1872) (finding a legal error when jury awarded pursuant to special verdict amount beyond insurance policy plus interest)). But see Murphy, supra note 93, at 766 (stating that re-examination of facts occurs under judgment as a matter of law).

Moreover, the Supreme Court has compared the demurrer to the evidence, a procedure that existed at English common law in 1791, to the procedures of directed verdict and judgment as a matter of law. See Galloway, 319 U.S. at 393-95 \& n.28. Under the Court's description of the demurrer to the evidence, once the defendant demurrered or admitted the facts that the plaintiff had shown at the trial and all the reasonable inferences that could be drawn from the facts, the English court determined whether the plaintiff won under the law that governed the case. See id. The Supreme Court stated that the main difference between the English demurrer and modem directed verdict or judgment as a matter of law was, under the demurrer, the defendant would lose if he was not correct that plaintiff's evidence was insufficient. See id. But see Ellen E. Sward, The Seventh Amendment and the Alchemy of Fact and Law, 33 SETON HALL L. REV. 573 (2003) (arguing that demurrer and other English procedures differed substantially from modern practices of summary judgment, directed verdict, and judgment as a matter of law).

This article takes no position as to the constitutionality of summary judgment, directed verdict, or judgment as a matter of law as applied by the federal courts.

126 Cf. Parklane Hosiery Co. v. Shore, 439 U.S. 322, 336 n.23 (1979) ("Collateral estoppel does not involve the 're-examination' of any fact decided by a jury.").

127 See id.

128 See supra note 118 (discussing different opinions on whether this procedure existed at common law).

${ }^{129}$ Like the majority, Justice Stevens, in his dissent, began his analysis with the assertion that the appellate court could reduce an excessive verdict as a matter of law. See 518 U.S. at 442-43 (Stevens, J., dissenting). Justice Scalia challenged the majority's and Justice Stevens' conclusion that a verdict could be reduced as a matter of law. See 518 U.S. at 453-54 \& n.3, 457 (Scalia, J., dissenting). He stated that appellate courts cannot change a judgment for excessive damages because only questions of law are within the purview of the appellate courts. See id. The appellate review of excessiveness of a jury's determination of damages necessarily involved the re-examination of facts. See id. at 460-61 (Scalia, J., dissenting); $c f$. Murphy, supra note 26, at 466-67 (arguing against the use of judgment as a matter of law for damages issues, not involving legal questions or for which "the facts could support no other result," for example when the damages were "sum certain"); Dorsaneo, supra note 5, at 1727-28 (stating that "reclassification of the issue as a law question is really a verbal charade that allows or requires the nullification of the jury's role in the litigation process because it implies that no deference whatsoever is required to be given to the jury's determination"). 
no statutory cap). ${ }^{130}$ The question of damages is a matter of fact. This question of fact in the case at hand is not turned into a question of law by the comparison of the case with other cases that have similar facts. The other cases simply contain other factual determinations, not legal determinations as to the correct amount of damages under certain facts.

Despite the characterization of the upper limit as a legal question, ${ }^{131}$ on remand if the district court granted the motion, the plaintiff would have the option of a new trial. As a result, the procedure, although unavailable at common law, at least facially maintains the jury's function at common law as the determiner of the facts. ${ }^{132}$ Thus post-Gasperini an evolving common law at minimum requires the maintenance of the jury's function at common law as the fact-finder. ${ }^{133}$

Justice Scalia criticized the majority's reading of the re-examination clause as not fixed and stated that the majority essentially merged the two clauses of the Seventh Amendment, obscuring any real difference between them. ${ }^{134}$ The majority's equation of the two clauses contrasts with the Court's early nineteenth century view that the second "clause of the amendment is still more important; and ... [is] a substantial and independent clause."135

Even accepting this equation of the clauses, the Court's recent jurisprudence regarding the common law in the first clause continues to support the

130 See supra note 54.

131 While there is no upper limit in cases of uncertain damages, assuming arguendo such a limit existed, if the upper limit was truly a legal question, it would appear not to require the option of a new trial. It seems unlikely that a new trial would be required so that the plaintiff can receive an equal or lesser amount. Although the majority and Justice Stevens do not go so far as to state that the plaintiff must take a remitted verdict and does not have the option of a new trial, the improper characterization of appellate factual review of a damages award as a legal question certainly may lead to the unconstitutional elimination of the option of a new trial by making the maximum damage suffered by the plaintiff a legal question and thus not subject to review under the Seventh Amendment's re-examination clause.

132 As discussed in this article, if a judge orders a remittitur, effectively there is no option for a new trial. See supra Part I.B; infra Part III.D.

${ }^{133}$ Cf. Balt. \& Carolina Line, Inc. v. Redman, 295 U.S. 654 (1935).

The aim of the Amendment... is... particularly to retain the common-law distinction between the province of the court and that of the jury, whereby, in the absence of express or implied consent to the contrary, issues of law are to be resolved by the court and issues of fact are to be determined by the jury under appropriate instructions by the court.

Id. at 657 (emphasis added).

134 See Gasperini v. Ctr. for Humanities, Inc. 518 U.S. 415, 461 (1996) (Scalia, J., dissenting); Woolley, supra note 115, at 505.

135 Parsons v. Bedford, 28 U.S. (3 Pet.) 433, 447 (1830). Note that Justice Story wrote both Parsons and Blunt. See Krauss, supra note 113, at 445-59; id. at 453 ("It ... seems clear that the First Congress understood 'the rules of the common law' to refer to English law and 'Suits at common law' to mean something else." (footnote omitted)). 
interpretation that "the common law" in the re-examination clause means the 1791 English common law. In another case decided in 1996, Markman v. Westview Instruments, Inc., ${ }^{136}$ the Court affirmed that " $[t]$ he right of trial by jury thus preserved is the right which existed under the English common law when the Amendment was adopted.' "137 Moreover, in 1999, in Del Monte Dunes, the Court stated that "[t]he Seventh Amendment ... applies ... to statutory causes of action 'analogous to common-law causes of action ordinarily decided in English law courts in the late 18th century.' "138 This jurisprudence shows that the English common law in 1791 governs the interpretation of the first clause of the Seventh Amendment. Thus, unless only the first clause is to be read to have a relation to the English common law in 1791, a conclusion defied by the text, 139 the Court's jurisprudence suggests that the English common law in 1791 governs the constitutionality of remittitur under the re-examination clause.

Although in Gasperini the Supreme Court expressly rejected a "fixed at 1791" interpretation of the common law, the actual analysis in Gasperini did not preclude this interpretation. Accepting the majority's conclusion that new trials on only damages, judgment as a matter of law and issue preclusion absent of mutuality of parties were unavailable at common law, the majority failed to discern whether their unavailability was a matter of mere non-existence or express proscription. This distinction is relevant to the analysis under the Seventh Amendment. A particular practice may have been unavailable at English common law for the simple reason that the English courts did not consider use of the particular innovation then. On the other hand, a practice may have been unavailable at English common law not merely because it was not considered but rather because the practice was expressly proscribed. Whatever interpretation is

136517 U.S. 370 (1996).

137 Id. at 376 (emphasis added) (quoting Balt. \& Carolina, Inc. v. Redman, 295 U.S. 654 (1935)) (deciding that English common law did not require jury to interpret patent claim and thus such determination was properly a judicial question). In applying English common law, Justice Souter stated that they did not address the possibility of conflict between such practice and American assumptions about the practice or conflict between English and American practice at the time. See id. For comparison purposes, the common law of the state and federal practice will also be examined. See infra notes 249-53 and accompanying text.

138526 U.S. 687, 708-09 (1999) (citing Feltner v. Columbia Pictures Television, Inc., 523 U.S. 340, 348 (1998) (quoting Granfinanciera, S.A. v. Nordberg, 492 U.S. 33, 42 (1989))); see also Feltner, 523 U.S. at 348-55 (deciding that, based on an historical analysis of "the common law and statutes in England and this country" in the eighteenth century, the Seventh Amendment required the jury to determine damages under the Copyright Act, although the Act provided that the court would make the assessment); see, e.g., Wooddell v. Int'l Bhd. of Elec. Workers, 502 U.S. 93 (1991) (stating that there is a right to jury trial on Labor-Management Report and Disclosure Act); Browning-Ferris Indus. v. Kelco Disposal, Inc., 492 U.S. 257, 280 n.26 (1989) ("[W]e are reluctant to stray too far from traditional common-law standards, or to take steps which ultimately might interfere with the proper role of the jury.").

${ }^{139}$ See supra text accompanying notes 95-113. 
given the phrase "rules of the common law," where a practice which re-examines facts found by a jury was proscribed, to then permit such a practice in federal court would violate the requirement of the Seventh Amendment that the facts found by a jury can be re-examined only according to the rules of the common law. If a practice could have been used at English common law and was not proscribed, the use of the practice in the federal courts would be consistent with the rules of the common law. ${ }^{140}$

The majority opinion in Gasperini permits an interpretation such that if a practice of re-examination was proscribed at English common law in 1791, it would be unconstitutional. Gasperini, at minimum, requires that, to be constitutional, a practice that did not exist under the English common law in 1791 must maintain the role of the jury as the fact-finder as the jury performed that function at common law. Moreover, current Supreme Court jurisprudence regarding the first clause supports the relevance of the 1791 English common law to the second clause.

\section{The Evolving Common Law}

The Gasperini majority arguably appeared to adopt a view of the common law in the re-examination clause as evolving. This view of the common law in the Seventh Amendment has been subject to much commentary. In a seminal work in which he reviewed the historical underpinnings of the Seventh Amendment, Charles Wolfram focused on the "common law" in the first clause. ${ }^{141} \mathrm{He}$ argued that the common law did not refer to English or state law in 1791 "but rather to the distinctive common-law process of adjudication and law-making that then and now, in England and in the United States, was recognized as flexible and changing." 142 Additional commentary on the "common law" in the Seventh Amendment is extensive, with many theories on how a court should interpret this phrase. What remains consistent throughout the commentary, however, is the maintenance of the jury as the fact-finder at minimum as it functioned at common law. ${ }^{143}$ For example, in response to the criticism that his "dynamic" interpretation

140 While jurisprudence and scholarship have yet to reveal clearly whether new trials on only damages, judgment as a matter of law, and issue preclusion absent mutuality of parties were expressly proscribed at English common law or simply not used at that time, the scholarship represented by this article conclusively determines that remittitur was unavailable because it was expressly proscribed. See infra text accompanying notes 152-248. Therefore, under Gasperini, because a fixed interpretation of the common law may remain relevant to practices proscribed at common law, remittitur is unconstitutional.

141 Wolfram, supra note 97.

142 Id. at 745.

${ }^{143}$ See, e.g., Woolley, supra note 115 , at 516-17 \& n.90 (stating that courts must focus on the "fundamental purpose" of the re-examination clause of "ensuring the proper balance of power between the federal judiciary and local juries"; "[C]ourts must give due consideration to 
of the common law allowed for much judicial and legislative discretion, Wolfram argued that this problem would be eliminated by the "tendency" to recognize only "post-1791 changes in common-law remedies and practices that would have the effect of enlarging the occasions for civil jury trial and the prerogatives of the civil jury."144

Under Gasperini, other Supreme Court jurisprudence and the text of the Seventh Amendment, the common law can be interpreted as fixed or tied to 1791 English practice with respect to procedures that the common law courts proscribed. Any re-examination of facts determined by a jury according to such proscribed practices is thus unconstitutional. However, this view of the common law as fixed with respect to these proscribed practices may not be accepted. Additionally, as to other practices not specifically proscribed or not used at common law, the relevance of the 1791 English common law practice may be discounted. If accepting a view of the common law as not fixed but evolving, then to be constitutional, the procedure of re-examination-here remittitur-must maintain the role of the jury as the fact-finder at least to the extent that it functioned as such at common law.

history, but need not attempt to replicate rigidly the balance of power that existed between local juries and the federal judiciary."); cf. Kirst, supra note 47, at 83 (arguing Seventh Amendment is evolving and remittitur is constitutional because it preserves the right to a jury trial); Matthew P. Harrington, The Economic Origins of the Seventh Amendment, 87 IOWA L. REV. 145, 151 (2001) (criticizing, in the context of interpreting the first clause, the Supreme Court's historical test and arguing for a "functional approach" to the availability of a jury based on juries' "limitations and abilities" and the type of case involved); Kenneth S. Klein, The Myth of How to Interpret the Seventh Amendment Right to a Civil Jury Trial, 53 OHIO ST. L.J. 1005, 1036 (1992) (stating that in the context of the first clause the drafters "left the leeway to future generations to craft ways to guarantee civil jury rights" and that "[i]f a legislature creates, by statute, a legal right which heretofore did not exist, the legislature can determine whether trial of that right should be to a jury, but in all other instances a litigant has an absolute right to a jury trial in a civil case in federal court."). But see AKHIL REED AMAR, THE BILL OF RIGHTS: CREATION AND RECONSTRUCTION 88-93 (1998). Amar focused exclusively on the scope of the jury trial right. Although Amar characterized Wolfram's work as " $[t]$ he leading scholarly work on the Seventh Amendment," he argued, contrary to Wolfram, for a "dynamic" approach under which each state's practice on when, if ever, a jury should decide a case would govern in the respective federal court and this law would shift as state law shifts. Id. at 91-93. This interpretation of the clause as tied to state law has been criticized as an impractical interpretation of the Amendment given widely differing state practices and the fact that states could decide not to adopt a jury trial right or to change this right at will. See Wolfram, supra note 97, at 73234; cf. Henderson, supra note 104, at 336 (stating three interpretations of the Seventh Amendment including: (1) jury available in cases in which there was a jury in state in 1790 (but then no guidelines for states which entered the union subsequently); (2) no procedural device that was not available in states in 1790 is permissible (but this would eliminate rational developments); and (3) the Supreme Court's practice of "preserving the substance of the common law trial by jury and particularly the jury's power to decide serious questions of fact, while allowing rational modifications of procedure in the interests of efficiency").

144 Wolfram, supra note 97 , at 746. 


\section{The Seventh AmENDMENT, The COMmon LAW, AND THE UNCONSTITUTIONALITY OF REMITTITUR}

Upon a motion for a new trial for excessive damages, a court may condition the denial of a grant of a new trial upon the plaintiff's acceptance of a remittitura reduced damages amount determined by the court. ${ }^{145}$ As shown here, this practice of remittitur has no cognizable basis in the English common law in the time period surrounding the adoption of the Seventh Amendment and is thus unconstitutional. For comparison purposes, the American common law is also discussed. Moreover, even accepting a view of the common law as evolving, the practice of remittitur is unconstitutional.

\section{A. Ascertaining the Relevant "[R]ules of the [C]ommon [L]aw"}

The phrase "according to the rules of the common law" in the Seventh Amendment is subject to various interpretations assuming that the English common law in 1791 applies. What establishes a practice as "according to the rules of the common law" is unclear. Must the courts in England have endorsed the practice to be "according to the rules of the common law," or is it sufficient that there is evidence of the practice in use in 1791, regardless of the prevalence of the practice? A middle ground would examine whether consistent authority for the practice exists.

The way to determine whether a practice existed under the English common law in 1791 is to examine the English common law in 1791, and in the time period immediately before 1791 , for a practice that has been endorsed by the common law courts. ${ }^{146}$ Also informative but less persuasive is the English common law at any time discussing the common law in and before 1791.147 Additionally, although even less persuasive, is the interpretation of American courts of whether there was a consistent practice under the English common law in and before 1791. ${ }^{148}$ Finally, the existence of a consistent practice in the English common law after 1791 can be considered. ${ }^{149}$

If there was a practice by some minority of judges at common law, this would not establish "the common law." For "the common law" in the Seventh Amendment to have any meaning, such a minority practice could not be "according to the rules of the common law." If it was so interpreted, then every practice, by one judge or all judges, would be "according to the rules of the

145 See supra text accompanying notes 25-35.

146 Cf. Dimick v. Schiedt, 293 U.S. 474, 476-85 (1935) (examining case law and treatises before and after adoption of Seventh Amendment).

${ }^{147}$ Cf. id.

148 Cf. supra note 137.

149 See Wolfram, supra note 97 , at 642 n.8. 
common law." 50 This would cause the terms "rules" and "common law" to lack any meaning. 151

\section{B. The Unconstitutionality of Remittitur Under the English Common Law}

In Dimick the Court stated that there was some English common law practice to reduce damages but cited to none. ${ }^{152}$ This has left only a vague suspicion to satisfy the Seventh Amendment analysis that English courts used some practice at common law akin to remittitur in the federal courts. ${ }^{153}$ To determine whether that suspicion has been in fact warranted requires a more thorough analysis of the English common law than the Supreme Court has pursued.

\section{1. "Remittitur" as a Device to Correct Errors in Pleadings Under the 1791 English Common Law}

This article's study of the English common law reveals that the practice of remittitur under the English common law was not the practice of remittitur as used today by the federal courts. English judges did not use remittitur to reduce jury verdicts. Rather, the plaintiff affirmatively used "remittitur" to correct potentially fatal errors in the court record in three primary ways. First, the jury could generally award only the amount of damages that the plaintiff alleged in the declaration, the English common law analogue to the modern complaint. ${ }^{154}$ If the jury awarded more than the amount that the plaintiff declared, the plaintiff could remit the amount greater than the declared amount, generally before the court entered judgment on that amount. This prevented defendant from prevailing on a writ brought for this error. For example, in the 1791 case of Pickwood v. Wright, the plaintiff had declared $£ 600$ in damages in an assumpsit action against the defendant. 155 The jury found $£ 611$ in damages and the court entered judgment for that amount. ${ }^{156}$ The defendant brought a writ of error because the judgment exceeded the amount that the plaintiff had requested. ${ }^{157}$ The Court of Common

${ }^{150}$ Note, however, that the analysis infra shows no evidence of a practice by any English judges of remittitur (as practiced in the federal courts) in the time period surrounding the adoption of the Seventh Amendment.

151 See supra text accompanying notes $95-113$.

152 See supra text accompanying notes 83-86.

153 See id.

154 See 7 CHARLES VINER, A GENERAL ABRIDGMENT OF LAW AND EQUITY 295 (London, $2 d$ ed. printed for G.G.J. and J. Robinson et al. 1791) (stating that "plaintiff shall recover no more than he has declared for").

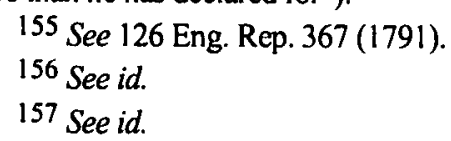


Pleas permitted an amendment, a remittitur of $£ 11$ of the judgment, if the plaintiff paid the costs of the writ of error. ${ }^{158}$

In these cases, the error that the plaintiff cured with remittitur was a discrepancy between the plaintiff's initial declaration and the verdict awarded by the jury. With remittitur the plaintiff relinquished only those damages awarded by the jury in excess of the plaintiff's declaration. The issue remittitur resolved in :these cases was not that the verdict awarded was in excess of what the court ideemed reasonable in relation to, for example, verdicts awarded in other cases.

${ }^{158}$ See id. Generally, courts did not permit a remittitur after judgment. See, e.g., Cheveley v. Morris, 96 Eng. Rep. 762 (1779); Sabin v. Long, 95 Eng. Rep. 475 (1743); Coy v. Hymas, 93 Eng. Rep. 1106 (1742); Ray v. Lister, 93 Eng. Rep. 446 (1738). But see Usher v. Dansey, 105 Eng. Rep. 770, 772 (1815) (holding that the plaintiff may remit or amend after judgment).

Before the adoption of the Seventh Amendment, there were cases in which the plaintiff attempted to remit damages awarded by the jury that were greater than he declared. See Coy v. Hymas, 93 Eng. Rep. 1106 (1742) (stating that plaintiff, who declared $£ 388$ in damages in debt action and received judgment for 388 pounds, zero shillings, and one pence and then attempted to remit one pence, must remit before judgment); Ray v. Lister, 93 Eng. Rep. 446, 447 (1738) (deciding that plaintiff, who declared $£ 10$ in damages in a debt action in which the jury found £30 in damages and judgment was entered on that amount, could not remit $£ 20$ in damages because judgment was entered on the verdict of £30); Strawn v. Fletter, 94 Eng. Rep. 542 (1733) (deciding judgment erroneous unless plaintiff remitted $\mathfrak{1} 80$ because plaintiff had declared $£ 20$ in damages and jury had found $£ 100$ ); Flemming v. Parker, 88 Eng. Rep. 85 (1722) (plaintiff declaring four counts and remitting damages as to three counts before judgment); Robert Pilfold's Case, 77 Eng. Rep. 1102 (1612) (plaintiff remitting $£ 9$ before judgment after declaring $£ 40$ and the jury finding $£ 49$ ); Persival v. Spencer, 80 Eng. Rep. 33 (1604) (reversing judgment for $£ 13$ after the plaintiff declared $£ 10$ and jury awarded $£ 13$ ).

After the adoption of the Amendment, additional cases referred to plaintiff's use of remittitur in this way. See Eyre v. Bank of England, 4 Eng. Rep. 213 (1819) (discussing remittitur in context of House of Lords' case where principal and interest were greater than damages declared in first two counts); Mills v. Funnell, 107 Eng. Rep. 616 (1824) (stating that plaintiff can remit statutory damages declared, for which there was no statutory tax owed); Bowden v. Home, 131 Eng. Rep. 277 (1831) (stating that plaintiff can remit damages in counts of declaration relating to promises he did not perform); King v. Birch, 114 Eng. Rep. 569 (1842) (remitting by plaintiff before judgment because he had declared for an amount greater than real debt).

As stated in Tidd's Practice, "[w]hen the jury give greater damages than the plaintiff has declared for, it may be cured by entering a remittitur of the surplus, before judgment." See 2 William Tidd, The Practice of the Courts of King's Bench, and Common PleAS, $\mathbf{N}$ Personal actions, and Ejectment: To Which are AdDed, The LaW and Practice of EXTENTS; AND THE RULES OF COURT, AND MODERN DECISIONS, IN THE EXCHEQUER OF PLEAS 896 (Phila., 3d Am. ed. R.H. Small 1840). Alternatively, "the plaintiff may amend his declaration and have a new trial." Id.; see also 3 SR JOHN COMYNS, A DIGEST OF THE LAWS OF ENGLAND 365 (London, 5th ed. A. Strahan 1822) ("[W] here a verdict is given for a greater sum than the amount of the damages laid in the declaration, and for that cause a writ of error is brought, the court will permit the plaintiff to enter a remittitur of the excess above the sum laid, on payment of the costs of the writ of error."). 
Rather, the damages were "excessive" simply as a matter of inconsistency with the amount that the plaintiff had declared.

This method of remittitur at English common law is not remittitur as practiced in the federal courts. Instead, this English common law of remittitur is comparable to the practice in federal court where the plaintiff may amend the declaration (and may not even be required to amend or in the first instance plead a specific dollar amount) in cases in which the jury awards damages greater than the plaintiff declared. 159

A second way that plaintiff used remittitur at English common law was to correct an insubstantial mistake regarding the damages in the declaration. The seminal common law case cited for this point throughout the eighteenth century is Duppa v. Mayo. ${ }^{160}$ In that case, the plaintiff sued the defendant for rent due to the plaintiff pursuant to a deed at a certain rate of rent per year.161 The plaintiff declared rent due for a period of thirty-seven years amounting to $£ 1110.162$ However, the plaintiff apparently misread the calendar, because according to the dates, rent could only have been due for $363 / 4$ years. ${ }^{163}$ The defendant realized the plaintiff's error and demurred. ${ }^{164}$ The plaintiff won judgment. ${ }^{165}$ However, the plaintiff discovered his error and entered a remittitur of the excess in his declaration to cure the record. ${ }^{166}$ The defendant then brought a writ of error, claiming the benefit of his demurrer. ${ }^{167}$ Under the decision, the plaintiff can remit an excessive declaration where the error in the declaration is not substantial to his underlying claim. ${ }^{168}$

${ }^{159}$ See FED. R. CIV. P. 8(a); FED. R. CIV. P. 54(c); see also Grunenthal v. Long Island R.R. Co., 393 U.S. 156, $157 \mathrm{n} .1$ (1968) (permitting plaintiff to amend complaint from $\$ 250,000$ to $\$ 305,000$ after jury found for $\$ 305,000)$.

16085 Eng. Rep. 366 (1670). Duppa v. Mayo is cited, for example, in 2 TIDD, supra note 158, Ingledew v. Crips, 92 Eng. Rep. 43 (1702), and Stafford v. Beneath, 88 Eng. Rep. 630 (1711); Ingledew and Stafford are discussed infra note 168.

161 See Duppa v. Mayo, 85 Eng. Rep. 366, 368 (1670).

162 See id.

163 See id. at 369.

164 See id.

165 See id.

166 See id.

167 See Duppa, 85 Eng. Rep. at 369.

168 Plaintiff used remittitur in this way in several other cases that arose prior to the adoption of the Seventh Amendment. In Ingledew v. Crips, 92 Eng. Rep. 43 (1702), for example, the plaintiff claimed the debt owed to him pursuant to the deed under which the defendant agreed to pay plaintiff $£ 35$ per load of wood. The plaintiff had declared damages on the amount of wood delivered to the defendant that included a half load. The damages declared by the plaintiff were in excess of what were possible under the deed, because, by its terms, he was due payment only for full loads of wood. The plaintiff remitted damages declared for the half load. On defendant's motion for arrest (reversal) of judgment, the question before court was whether plaintiff's remittitur effectively cured his defective declaration. The court held that 
Here unlike the first use of remittitur described above, the plaintiff remitted excessive damages in his declaration rather than in the verdict. A federal law analogy to this common law use of remittitur is Federal Rule of Civil Procedure 15(a), which permits parties to amend pleadings once as a matter of course prior to response, and otherwise "when justice so requires."169 There is no similarity, however, between the English common law practice that permits the plaintiff to remit an excess in his declaration and remittitur as used by the federal courts.

Finally, at English common law, the plaintiff used remittitur to cure an error in cases in which a verdict was awarded on all the counts although one of multiple counts was invalid. There, the defendant could move for arrest (or reversal) of judgment. To avoid an arrest, the plaintiff could remit damages awarded on the invalid count and collect from the others. For example, in Flemming $v$. Parker, ${ }^{170}$ the plaintiff had entered a declaration consisting of four counts. At nisi prius (the trial below), defendant pled to three counts and demurred to one. ${ }^{171}$ The plaintiff won judgment on the defendant's demurrer and a jury was charged to assess damages on that count. ${ }^{172}$ The inquest jury sent up its recommendation for final judgment. ${ }^{173}$ The defendant moved for arrest of judgment for error on the face of the record. ${ }^{174} \mathrm{He}$ argued that judgment on the count to which he demurred was improper because the plaintiff had not dismissed the three counts to which the defendant had pled. ${ }^{175}$ However, because the

it was curative because the amount of wood actually delivered was not determinative of plaintiff's underlying claim. See also Pierson v. Dunlop, 98 Eng. Rep. 1246 (1777) (using remittitur to cure the excessiveness of the plaintiff's declaration after the plaintiff suppressed evidence that the defendant had paid him part of a debt); Baskerville v. Brown, 96 Eng. Rep. 164 (1761) (using remittitur to cure an error in the plaintiff's declaration where the defendant suppressed evidence of his counterclaim, rendering the plaintiff's declaration in excess of what the evidence could demonstrate); Stafford v. Beneath, 88 Eng. Rep. 630 (1711) (discussing the possibility of plaintiff remitting the damages over $£ 15$ because the plaintiff demanded $£ 15$ and proved 122 and defendant demurred); Thwaites v. Ashfield, 88 Eng. Rep. 1187 (1696) (permitting plaintiff to remit excess declared for rent). For an additional discussion of Baskerville and Ingledew, see FRANCIS BULLER, AN INTRODUCTION TO THE LAW RELATIVE TO TRIALS AT NISI PRIUS 181, 190-91 (Dublin, printed for Elizabeth Lynch 1773).

Other cases after the adoption of the Seventh Amendment used remittitur in this way as well. See Mills v. Funnell, 107 Eng. Rep. 616 (1824) (finding that plaintiff's remittitur of damages claimed for four bushels of coal cured inconsistency with the statute under which the damages were claimed that assessed tax per chaldron); Simmons v. Wood, 114 Eng. Rep. 1212 (1843) (holding that plaintiff's declaration would be cured by remittitur of interest declared that could not be proved).

169 FED. R. CIV. P. 15(a).

17088 Eng. Rep. 85 (1722).

171 See id. at 85.

172 See id.

173 See id.

174 See id.

175 See id. 
plaintiff had entered a remittitur of the damages declared on those counts prior to judgment, the Court held that judgment could be entered on the count to which defendant demurred. ${ }^{176}$ The plaintiff's remittitur of damages on specific counts; had the same effect as an entry of nolle prosequi to those counts (or a. discontinuance of those claims). ${ }^{177}$

176 See 88 Eng. Rep. at 85; see also Nutton v. Crow, 93 Eng. Rep. 274 (1713) (remitting of two invalid counts by plaintiff which salvaged judgment on third valid count); Pinkney v. Inhabitants de Rotel, 2 Saund. 379, 380 (1671) (citing Duppa v. Mayo, 85 Eng. Rep. 366 (1670)) (winning judgment on valid counts for money and remitting of invalid counts for goods); Cutting v. Williams, 87 Eng. Rep. 1160, 1161 (1702) (entering judgment in whole against defendant although plaintiff brought two counts, one of which was void, because "if a remittitur be not entered for part, that it will be bad for all; for the judgment is of the whole").

For cases after the adoption of the Seventh Amendment, see Dadd v. Crease, 149 Eng. Rep. 742 (1833) (allowing plaintiff to preserve judgment on seventh of ten counts where Court found error in other nine by entering remittitur of damages as to other nine counts), and 3 COMYNS, supra note 158, at 370 ("So, if entire damages are given, when an action does not lie for part, if the plaintiff releases his damages and costs, he shall have judgment for the part which is good.").

Plaintiff could also cure an error in the record in cases involving multiple defendants to an action. See 2 TIDD, supra note 158, at 896 ("Where in an action against several defendants, the jury by mistake have assessed several damages, the plaintiff may cure it by entering a remittitur as to the lesser damages, or even without remittitur may take judgment against all for the greater damages."); see also 3 COMYNS, supra note 158, at 367, 372 ("So, if in a joint action of trespass, [etc.] several damages are assessed; it shall be aided by a release, or nolle prosequi against all but one of defendant."). At least in some such cases it was beneficial for the plaintiff to cure the record by entering a remittitur of the least of the damages awarded against multiple defendants. See Johns v. Dodsworth, 79 Eng. Rep. 768 (1630) (allowing, but not requiring, plaintiff to enter remittitur of the lesser of several damages against one defendant to collect greater from both defendants); Sir John Heydon's Case, 77 Eng. Rep. 1150 (1615) (allowing plaintiff to remit to avoid erroneous judgment when separate writs of inquiry against different defendants results in several damages).

The case of Sabin v. Long, 95 Eng. Rep. 475 (1743), demonstrates how the plaintiff might have entered a remittitur of the lesser of several damages awarded against multiple defendants to try to collect the larger damage award from all defendants. See id. at 475 . The plaintiff brought an action in trespass against three defendants. See $i d$. Two of the defendants pleaded and judgment was awarded against them for thirty-five shillings. See id. The third defendant lost judgment by default. See id. The plaintiff secured a writ of inquiry on the default and the jury found damages of two shillings. See id. Judgment was entered for thirty-five shillings against the first two defendants and two shillings against the third. See id. Subsequently, the plaintiff moved to remit the two shillings damages awarded against the third plaintiff so as to hold the large thirty-five shillings award against all three. See id. The court held that the plaintiff could either take the greatest damages from the two defendants or remit the two shillings damages against the one defendant, but could not hold the entire judgment against all three. See id. Similarly, prejudgment remittitur of a verdict against one of many defendants constituted dismissal of the claim against that defendant.

177 See Eyre v. Mount, 95 Eng. Rep. 133, 133-34 (1736). To th : defendant's writ of error on grounds that plaintiff had merely remitted part of the damages, Chief Justice Hardwicke responded, "What authority have you for that? There is no occasion for it, for the remittitur is a 
Again, this practice is unlike federal remittitur. The most apparent comparison between the common law practice and federal procedure today would be voluntary dismissal with prejudice under Federal Rule of Civil Procedure 41(a)(2), which provides that subsequent to service to an adverse party, the plaintiff may voluntarily dismiss his claim, "upon order of the court and upon such terms and conditions as the court deems proper."178

The common law use of remittitur by the plaintiff to correct the record does not resemble the use of remittitur by the federal courts to reduce jury verdicts according to the judge's determination of the damages in a case. The question then becomes whether at English common law the practice now known as remittitur existed but was referred to by a different name.

\section{The Unavailability of Federal Remittitur Under the 1791 English Common Law}

Under the English common law, the jury was the supreme determiner of the facts in the judicial system. Distinguishing the power of the jury to determine facts and the power of the judge to determine the law, in 1768, William Blackstone stated:

[T]n settling and adjusting a question of fact, when intrusted to any single magistrate, partiality and injustice have an ample field to range in; either by boldly asserting that to be proved which is not so, or more artfully by suppressing some circumstances, stretching and warping others, and distinguishing away the remainder. Here therefore a competent number of sensible and upright jurymen, chosen by lot from among those of the middle rank, will be found the best investigators of the truth, and the surest guardians of public justice. ${ }^{179}$

release for so much, and is like an acknowledgment of satisfaction." Id. at 133-34. In Bowden v. Horne, 131 Eng. Rep. 277 (1831), the court stated:

[F]or in the case of a remittitur of part of the damages, the entry is, "and hereupon the said Plaintiff freely here in Court remits to the said Defendant all damages sustained by him the said Plaintiff by reason of the not performing the several promises and undertakings in the two last counts of the declaration mentioned; therefore let the Defendant be acquitted of such damages so remitted as aforesaid, and go thereof without [delay]," [etc.]

Id. at 279. Analogizing remittitur to nolle prosequi, Justice Tindal further expounded that the effect of remittitur "is that of a final giving up of the damages by matter of record . . . the nature of [the plaintiff's] original demand is changed." See id.

178 FED. R. CIV. P. 41(a)(2).

1793 WILLIAM BLACKSTONE, COMMENTARIES ON THE LAW OF ENGLAND 380 (Oxford, 2d ed. Clarendon Press 1768); cf. Dennis R. Nolan, Sir William Blackstone and the New American Republic: A Study of Intellectual Impact, 51 N.Y.U. L. REV. 731 (1976) (discussing the impact Blackstone had on the American law, including the Constitution). 
Consistent with this commentary, at common law, courts did not interfere with the determination of the jury of the damages (a fact), other than to order new trials in cases in which the court found the damages excessive. 180

\section{a. The Powerlessness of Courts to Unconditionally Reduce Jury Verdicts}

Courts had no power to reduce damages outright. In the 1764 case of Beardmore $v$. Carrington, ${ }^{181}$ in the context of denying a motion for a new trial in a tort case, the King's Bench emphasized that "there [was] not one case to be found in the Year-Books where ever the Court abridged the damages after a principal verdict."' 182 A principal verdict was a verdict after trial by jury. This verdict contrasted with a verdict upon a writ of inquiry. There a judge asked the jury for an advisory opinion that the judge was not required to follow. ${ }^{183}$ Even upon a writ of inquiry, where the jury awarded excessive damages, the court would not abridge the damages but would award a new writ of inquiry by jury. ${ }^{184}$ Thirty years after the adoption of the Seventh Amendment, in Eyre v. Bank of England, ${ }^{185}$ the court stated that since 1729 and up until 1819, "there [was] no recorded instance of any exercise of power by the Courts to increase or abridge the damages assessed by a jury upon verdict or writ of inquiry."186

Several English common law treatises, published contemporary to the ratification of the Seventh Amendment, discuss the issue of the reduction of damages by a court or an analogous issue from which the conclusion can be drawn that courts did not reduce damages. Sayer's The Law of Damages, published in 1770 , states that courts never reduced damages assessed by juries in cases in which damages was an issue for the jury: "The [p]ower of abridging such [d]amages which have been assessed by the [j]ury ... is not at this [d]ay exercised

180 See infra Part III.B.3.

18195 Eng. Rep. 790 (1764).

$182 \mathrm{Id}$. at 792. Beardmore $v$. Carrington has been cited in support of the existence of remittitur in 1791. See Snyder, supra note 16, at $302 \&$ n.21. However, there is nothing in that case indicating remittitur existed; in fact it is quite the opposite, as noted above.

183 See Renee B. Lettow, New Trial for Verdict Against Law: Judge-Jury Relations in Early Nineteenth-Century America, 71 NOTRE DAME L. REV. 505, 510 n.23 (1996) (explaining writ of inquiry). But see Oldham, supra note 55 (arguing that judges could decide damages only upon the plaintiff's consent and in cases of uncertain damages, a jury was always required).

184 See 2 TIDD, supra note 158.

1854 Eng. Rep. 213 (1819).

186 Id. at 219. In Hayward v. Newton, 94 Eng. Rep. 432 (1732), in discussing that new trials have sometimes been granted for excessive damages, the Chief Justice of King's Bench noted that courts had sometimes increased damages in violent batteries or mayhem cases. Id. at 432. The lack of any reference to decreasing damages in the context of discussing new trials for excessive damages certainly implies the lack of any such practice or authority. 
in any [a]ction."187 Viner's Abridgment, published in 1791, iterates the same rule that "[d]amages are given at the nisi prius [(the trial court)] in an action where damages are the principal, and the Court ... cannot mitigate nor encrease [sic]."188 Although commenting extensively on the jury trial right and the procedures to alter a verdict, in his Commentaries published in 1768, Blackstone does not mention any power of the court to reduce damages. ${ }^{189}$ Also, Buller's An Introduction to the Law Relative to Trials at Nisi Prius, published in 1773, discusses new trials for excessive damages and other procedural devices after a jury trial but makes no mention of a court's power to reduce damages. ${ }^{190}$

Several other treatises published after the adoption of the Seventh Amendment discuss the English common law in the time period surrounding the adoption of the Seventh Amendment and either explicitly state or imply that English common law courts did not have the power to reduce damages. Comyns' A Digest of the Laws of England discusses how a court could increase damages, but does not discuss a court's power to decrease damages. ${ }^{191}$ Tidd's Practice provides further indication that courts had no power to reduce damages, as it explicitly notes a court's power to increase damages in actions of mayhem, yet makes no reference to the power to abridge damages in any case. ${ }^{192}$ Bacon's Abridgement also specifically states that a court cannot abridge damages on a principal verdict. ${ }^{193}$ Finally, Mayne's Treatise on Damages states that the authors are "not aware of any instance in which such a jurisdiction [to increase or decrease damages] has been exercised in modern times."194 Thus, under cases

187 JOSEPH SAYER, THE LAW OF DAMAGES 173 (London, W. Strahan \& M. Woodfall 1770) (citing, among other cases, Delves v. Wyer, 1 Brownl. \& Golds. 204 (1569-1624) (stating, after jury awarded $£ 40$ in damages, that it could not reduce the damages because jury properly determined issue of damages, although plaintiff would have accepted $£ 5$ ), Bonham v. Lord Sturton, 1 Dyer. 105 a. (1554) (denying defendant's request to reduce verdict for 500 marks against defendant, because it was a principal verdict), and Hawkins v. Sciet, 81 Eng. Rep. 1099 (1668) (stating that damages cannot be reduced because jury is proper judge of damages)).

1887 VINER, supra note 154, at 270 (citing, among other cases, Bonham v. Sturton and Hawkins v. Sciet). Both Sayer and Viner indicate that where an inquest jury assessed damages, the court could increase or decrease them for any reason. The reasoning was that the inquest jury only informed the justices in cases where the justices themselves had the power to determine the amount of damages. See SAYER, supra note 187, at 194; 7 VINER, supra note 154 , at 271,273 . But see supra note 183.

189 See 3 BLACKSTONE, supra note 179, at 386-401.

190 See BULLER, supra note 168 , at 352.

191 See 3 COMYNS, supra note 158, at 356-58.

192 See 2 TIDD, supra note 158, at 896.

193 See 3 Matthew Bacon, A New Abridgement of the Law 75 (Phila., T \& J.W. Johnson 1876).

194 COLEMAN PhILliPSON, MAYNE’S TREATISE ON DAMAGES 571 (9th ed. 1920). 
and treatises decided and published before and after the adoption of the Seventh Amendment, courts had no power to reduce jury verdicts outright.

\section{b. The Powerlessness of Courts to Reduce Jury Verdicts with the Consent of One Party}

In two cases, decided over a century after the adoption of the Seventh Amendment, the House of Lords directly discussed the propriety of the practice of remittitur as now practiced in the federal courts. The cases, Watt $v$. Watt ${ }^{195}$ and Lionel Barber \& Co. v. Deutsche Bank, ${ }^{196}$ confirm that under the common law in 1791, a court could not reduce a jury's verdict as an alternative to a new trial for excessive damages upon the verdict winner's consent to the reduction.

In Watt, the jury had found $\mathfrak{£ 5 0 0 0}$ in damages. ${ }^{197}$ Ruling the damages excessive, the Court of Appeal decided that the plaintiff could consent to a reduction from $£ 5000$ to $£ 1500$ or alternatively take a new trial. ${ }^{198}$ In reversing the Court of Appeal, the House of Lords decided that to avoid a new trial, both the plaintiff and defendant must consent, which had not occurred in that case. ${ }^{199}$ In three different opinions, the importance of the jury trial right was emphasized. Two Lords stressed the defendant's right to a jury trial and thus his required consent, in addition to the plaintiff's, in cases in which a reduction is proposed as an alternative to a new trial. ${ }^{200}$ One also stated that while reductions in damages with only the plaintiff's consent may "have been frequently made" those orders were not challenged. ${ }^{201}$ It had been wise for defendants not to appeal the reduction to save the expense and eliminate the risk of a new trial. ${ }^{202}$ The Lord went on to criticize the Court of Appeal in Belt $v$. Lawes for its decision that accepted this practice without citing any authority. ${ }^{203}$ Additionally, another Lord distinguished the former English practice of inquisition by a jury, where the jury gave an advisory opinion, from trial by jury, stating that only under inquisition by

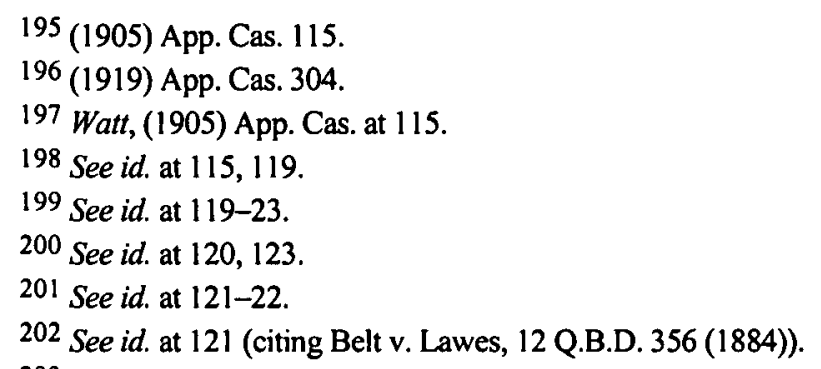

203 See Watt, (1905) App. Cas. at 122. Moreover, as pointed out by the defendant's attorney, the court in Belt decided that remittitur was not appropriate in that case, and accordingly it could certainly be argued that Belt does not set forth a convincing argument for the practice of remittitur. See id. at 116. 
jury as opposed to trial by jury, the court could reject the amount determined by the jury. ${ }^{204}$

The subsequent case of Barber discussed a reduction of a jury verdict in the context in which the lower court judge had erroneously instructed the jury that certain damages had been proved that had not been so proved. ${ }^{205}$ Thus, the issue there was not excessive damages but rather whether the court should reduce the verdict where there had been an error in the case which may have caused the jury to award more damages than it would have otherwise ordered. ${ }^{206}$ Barber contrasts with federal cases in which a remittitur is ordered where the damages are claimed to be excessive and where there is no error during the trial.

The House of Lords decided that the plaintiff could consent to a reduction of the damages instead of being required to take part in a new trial. ${ }^{207}$ They distinguished Watt, where the House had rejected the reduction of the verdict because the lower Court of Appeal had attempted to impose its own assessment of reasonable damages. ${ }^{208}$ The House reasoned that here, unlike in Watt, the possible amount of error by the jury was definite and a reduction by that amount would not be the House's or Court of Appeal's determination of damages, but rather a reduction of the sum assessed by the jury that may have been attributed to the trial judge's error (not the jury's error) ${ }^{209}$ The House, by a vote of three to two, decided the plaintiff alone could consent to the reduction. ${ }^{210}$ One of the three judges in the majority, however, described the case as "near the line," citing Watt, and expressed serious reservations about the appropriateness of a reduction without the consent of the plaintiff and defendant. ${ }^{211}$ The two dissenting judges similarly stated a reduction of the verdict was improper without the consent of both parties. 212

Watt and Barber show that even in the twentieth century the English courts rejected the practice of remittitur as used by the federal courts. Upon a new trial for excessive damages, in a case in which there was no legal error, a court could not reduce a verdict upon the consent of the verdict winner.

\footnotetext{
204 See id. at 119. But see supra note 183.

205 See Barber, (1919) App. Cas. at 313.

206 See id. at $313,318,330$.

207 See id. at 304, 315.

208 See id. at 314-15.

209 See id.

$210 \mathrm{Id}$. at 304.

211 Barber, (1919) App. Cas. at 304, 319.

212 See id. at 304, 327, 335-36.
} 


\section{c. The Powerlessness of Courts to Reduce Jury Verdicts to Maximum Reasonable Sums Declared by the Courts}

In federal court, both the plaintiff (by accepting the reduction) and the defendant (by moving for the reduction) may consent to the reduction of the verdict. The issue that emerges is whether then remittitur as used by the federal courts is consistent with Watt and Barber. As a preliminary matter, Watt and Barber do not constitute the common law in 1791, because they were decided in the twentieth century. ${ }^{213}$ The analysis essentially could end there.

Yet even assuming some relevance for these cases, the cases involve a practice that is unlike the practice of federal remittitur. In Watt and Barber, there is no indication that the judge told the parties that any amount suggested by the court was the maximum amount that a "reasonable" jury could find. ${ }^{214}$ As a result, the "consent" of the parties may indeed actually constitute "consent."215 By contrast, in federal court, although the plaintiff and the defendant may verbally "consent" to a remittitur, plaintiff has no effective choice to take the new trial and not to take the remittitur because the judge has pronounced the remitted verdict, the maximum verdict that a reasonable jury could find. ${ }^{216}$ Accordingly, "consent" would be an inaccurate characterization of plaintiff's action to take the remittitur. This shows that if indeed Watt and Barber are relevant to the English common law analysis, the possible consent of both plaintiff and defendant, to which those cases refer, is not comparable to remittitur as practiced in the federal courts, which does not involve such consent by plaintiff. 217

\footnotetext{
213 See supra text accompanying notes 146-50.
}

214 Although there is no discussion of any outright reduction of a verdict by a court, in one case decided prior to the Seventh Amendment, there is brief mention of a compromise between the parties and the acceptance by the plaintiff of some amount less than the jury verdict. See The King v. Watson, 100 Eng. Rep. 108, 108 (1788). It is unclear whether the court itself suggested the amount that was accepted by the plaintiff. See id.

215 Additionally, in Barber, in which the court ordered an alternative reduction, the Court emphasized the legal error and the definity of the error. See supra text accompanying notes 205-12.

216 See supra Part I.B; infra Part III.D.

217 A second issue emerging from these cases is whether in 1791, English common law courts reduced damages but there is no record of this occurrence because the defendant did not appeal. See supra text accompanying notes $201-02$. This should not be the case as is evident from the discussion in the case law and treatises published in the 1791 time period. See supra text accompanying notes 182-215. 


\section{The Motion for a New Trial for Excessive Damages Under the 1791 English Common Law}

In addition to the cases and treatises demonstrating that English common law courts did not reduce verdicts in and around 1791, there is other evidence that remittitur as practiced by the federal courts was not established in the eighteenth century in the English common law courts. A persuasive indication is the case law on new trials for excessive damages. In decisions regarding motions for new trials for excessive damages, courts never mention a possible "remittitur" or a reduction of the verdict as an alternative to a new trial. ${ }^{218}$ If indeed judges could reduce verdicts, as an altemative to a new trial, "remittitur" or a reduction of the verdict would be found in at least a number of decisions. No evidence of this exists, however.

In fact, a court generally would order a new trial for excessive damages only in cases in which the damages were so high as to indicate prejudice or partiality of the jury. ${ }^{219}$ Tidd's Practice stated that "a new trial may be had for excessive damages; but in that case, the damages ought not to be weighed in a nice balance, but must be such as appear at first blush to be outrageous, and indicate passion or partiality in the jury." 220 Beardmore echoes this principle. The Justices stated that "[a]ll, or most of the cases of new trials, are where juries have misdemeaned themselves contrary to their oath."221

In those cases in which the English common law courts granted new trials for excessive damages, damages were generally calculable, as in contract or debt cases, in contrast to cases in which damages were uncertain, such as in tort

218 See infra notes 235-41 and accompanying text; cf. Bright v. Eynon, 97 Eng. Rep. 365, 366 (1757) ("[A] general verdict can only be set right by a new trial: which is no more than having the cause more deliberately considered by another jury; when there is a reasonable doubt, or perhaps a certainty, that justice has not been done." (emphasis added)).

219 The new trial for excessiveness replaced attaint, where the jury was prosecuted for misconduct. See Barker v. Dixie, 95 Eng. Rep. 180, 181 (1736); Duberley v. Gunning, 100 Eng. Rep. 1226, 1227 (1792); PHILLIPSON, supra note 194, at 584; 2 TIDD, supra note 158, at 904, 905, 908; Lettow, supra note 183, at 511; Murphy, supra note 27, at 188-89 (eighteenthcentury judicial review deferential to jury).

${ }^{220} 2$ TIDD, supra note 158 , at 908.

${ }^{221}$ Beardmore v. Carrington, 95 Eng. Rep. 790, 793 (1764); see also Leith v. Pope, 96 Eng. Rep. 777, 778 (1779) (stating that "in cases of tort the Court will not interpose on account of the largeness of damages, unless they are so flagrantly excessive as to afford an internal evidence of the prejudice and partiality of the jury" (footnote omitted)); Fabrigas v. Mostyn, 96 Eng. Rep. 549, 549 (1773) (stating that "the jury (not the Court) are to estimate the adequate satisfaction .... No prejudice or misbehaviour of any kind are or can be imputed to the jury."); Perkin v. Proctor, 95 Eng. Rep. 874, 877 (1768) (stating that the jury "are the constitutional judges as to damages; and there must be some very extraordinary conduct in a jury to induce the Court to meddle with damages"). Blackstone described that a new trial could be granted if the jury rendered "exorbitant damages." 3 BLACKSTONE, supra note 179, at 387. 
cases.222 For example, the King's Bench granted a new trial for excessive damages in Pleydell $v$. Earl of Dorchester, ${ }^{223}$ a case in which defendant had diverted the water-course of the plaintiff. ${ }^{224}$ The court differentiated that case of certain damages from tort cases. ${ }^{225}$ The court stated "it being a mere question of property as stated on the record, where there was something whereby to measure the damages, namely, the deterioration of the property itself; and therefore not like cases of personal injuries, as actions for adultery, slander, [etc.]"226

In contrast to cases of certain damages, in the immediate time period before the adoption of the Seventh Amendment, there is no sustainable evidence of new

222 See BULLER, supra note 168, at 326C:

In actions founded upon torts, the jury are the sole judges of the damages, and therefore in such cases the court will not grant a new trial on account of the damages being trifling or excessive. But in actions founded upon contract, and where debt would lie... the Court will enquire into the circumstances of the case, and relieve if they see reason.

See also Snyder, supra note 16, at 303-04.

Courts did not engage in a comparison of the facts of one case as compared to the facts in another case to determine whether damages were excessive. See Murphy, supra note 27, at 190-92. While correctly recognizing comparative review did not exist under the English common law, Professor Murphy incorrectly argues that comparative review "does not seem to pose any greater intrusion on the jury's decisional province under the Seventh Amendment than traditional judicial review." See Murphy, supra note 27, at 190-92. Comparative review does pose such a greater intrusion into the jury's role under the Seventh Amendment than under the English practice. Implicit in such a comparative review is the belief that a judge can compare the facts in different cases and through this "comparison" determine the highest amount of damages with certainty in a particular case. A direct result of this belief would seem to be more review of damage awards, thus impinging on the jury's role more than under the English common law practice where judges simply looked at the facts and damages in a particular case to determine whether the damages appeared outrageous.

223101 Eng. Rep. 1115 (1798).

224 See id. at 1115.

225 See id.

226 Id. (emphasis added); see Seale v. Hunter, 98 Eng. Rep. 515, 516 (1772) (granting new trial for excessive damages in certain damages cases (regarding value of greyhound) because damages awarded by jury greater than plaintiff declared); Earl of Peterborough v. Sadler, 88 Eng. Rep. 1371 (1700) (granting new trial for excessiveness and then granting new trial for inadequate damages in a non-tort case concerning a farmer's improvement to land and the value of that improvement); Leeson v. Smith, 4 Nev. \& M. 304, 306 (1834) (granting new trial in debt action in which the parties were given the alternative to instead consent to reduction in verdict, the amount of which the court did not give an opinion; "we cannot ... reduce the damages without the consent of both parties"); Rolin v. Steward, 139 Eng. Rep. 245, 250 (1854) (involving parties that agreed to a reduction in the verdict in a contracts case in which defendant moved for a new trial on the ground of excessive damages, and the Court of Common Pleas had suggested that the amount of damages may be too large but did not state explicitly an amount by which the verdict was excessive). 
trials for excessive damages in cases of uncertain damages. ${ }^{227}$ For example, in the 1764 Beardmore case, the King's Bench, denying a motion for a new trial for excessive damages in an action for trespass and false imprisonment, emphasized that there had never been a new trial granted for excessive damages in a tort case. ${ }^{228}$ The Court made the point that

[t]here is great difference between cases of damages which be certainly seen, and such as are ideal, as between assumpsit, trespass for goods, where the sum and value may be measured, and actions of imprisonment, malicious prosecution, slander, and often personal torts, where the damages are matter of opinion, speculation, ideal. 229

Subsequently, the King's Bench engaged in another similar discussion. Denying a motion for a new trial for excessive damages in a trespass case, the King's Bench differentiated between contract and tort cases. ${ }^{230}$

In contract the measure of damages is generally matter of account, and the damages given may be demonstrated to be right or wrong. But in torts a greater latitude is allowed to the jury: and the damages must be excessive and outrageous to require or warrant a new trial. ${ }^{231}$

${ }^{227}$ In a case more than sixty years before the adoption of the Seventh Amendment, a court granted a new trial for excessive damages in a malicious prosecution case. See Chambers v. Robinson, 93 Eng. Rep. 787, 788 (1726). Many cases in the time period around the adoption of the Amendment condemned Chambers as wrongly decided. Beardmore dismissed any relevance of this case because in Chambers the court stated that the defendant should be given "a chance of another jury"; after the second verdict resulted in the same verdict as the first, the court stated that it had no authority to order a third trial. See Beardmore v. Carrington, 95 Eng. Rep. 790, 793 (1764). Additionally, in the time period significantly prior to the adoption of the Seventh Amendment, there were new trials in only a few cases that involved uncertain damages, and there appears to be special circumstances in each of those cases. See Bickley \& Bickley, 94 Eng. Rep. 231 (1730) (granting new trial when only evidence of damages came from improper witnesses); Clerk v. Udall, 91 Eng. Rep. 552 (1702) (refusing to grant a third trial after granting new trial for excessive damages and giving same damages in second trial); Ash v. Ash, 90 Eng. Rep. 526 (1695) ("The jury were very shy of giving a reason of their verdict, thinking they have an absolute despotick power, but I did rectify that mistake, for the jury are to try causes with the assistance of the Judges, and ought to give reasons when required, that, if they go upon any mistake, they may be set right, and a new trial was granted."(apparently some improper evidence was heard by the jury)); Wood \& Gunston, 82 Eng. Rep. 867 (1655) (granting new trial for excessive damages (and possibly juror partiality) in trespass for words case).

22895 Eng. Rep. 790, 793 (1764).

229 Id. at 792.

230 Sharpe v. Brice, 96 Eng. Rep. 557 (1774).

231 Id. at 557. 
Another case in this time period before the adoption of the Seventh Amendment, the 1763 case Huckle v. Money, 232 is illustrative of the legal immeasurability of tort damages. Denying the motion for a new trial for excessive damages, the Chief Justice of the King's Bench emphasized that

the law has not laid down what shall be the measure of damages in actions of tort; the measure is vague and uncertain, depending upon a vast variety of causes, facts, and circumstances; torts or injuries which may be done by one man to another are infinite; in cases of criminal conversation, battery, imprisonment, slander, malicious prosecutions, [etc.] the state, degree, quality, trade or profession of the party injured, as well as of the person who did the injury, must be, and generally are, considered by a jury in giving damages. ${ }^{233}$

23295 Eng. Rep. 768 (1763).

233 Id. at 768. Prior to the adoption of the Seventh Amendment, courts denied a new trial for excessiveness in numerous cases. See Bennett v. Allcott, 100 Eng. Rep. 90, 90-91 (1787) (denying new trial for excessiveness in trespass, debauching case); Ducker v. Wood, 99 Eng. Rep. 1092 (1786) (denying a motion for a new trial for excessive damages in an assault case); Gilbert v. Berkinshaw, 98 Eng. Rep. 911, 912-13 (1774) (denying new trial for excessive damages in defamation case with one Justice stating that while a new trial may sometimes be required, "I do not think it fit that this Court shall say, in a matter of uncertain damages, there shall be a new trial, because if the Court had been to fix the damages they might have given less, or a jury might have given less."); Tullidge v. Wade, 95 Eng. Rep. 909, 910 (1768) (denying new trial for excessive damages in case for trespass for the pregnancy of plaintiff's daughter and stating: "In actions of this nature, and of assaults, the circumstances of time and place, when and where the insult is given, require different damages; as it is a greater insult to be beaten upon the Royal Exchange, than in a private room.'); Redshaw v. Brook, 95 Eng. Rep. 887,888 (1769) (denying new trial for excessive damages in trespass case with one judge specifically recognizing that a judge might think the jury's verdict was too large but stating "how can we draw the line to fix the measure of damages in this case" and commenting that if he were one of the jury "some of them might have convinced [him] that [the] damages are little enough"); Benson v. Frederick, 97 Eng. Rep. 1130 (1766) (denying new trial for excessive damages after writ of inquiry in case where plaintiff was stripped and beaten); Grey v. Grant, 95 Eng. Rep. 794 (1764) (denying new trial for excessive damages in assault and battery case); Wilford v. Berkeley, 97 Eng. Rep. 472 (1758) (denying new trial for excessiveness in an action for criminal conversation with plaintiff's wife and stating the jury was the sole proper body to determine damages in this type of case).

After the adoption of the Seventh Amendment, courts continued to deny new trials for excessiveness. See Chambers v. Caulfield, 102 Eng. Rep. 1280, 1285 (1805) (denying new trial for excessiveness in criminal conversation case because "from the amount of the damages given as compared with the facts of the case laid before the jury," it appeared jury did not act "under the influence either of undue motives, or some gross error or misconception on the subject"); Irwin v. Dearman, 103 Eng. Rep. 912 (1809) (denying new trial for excessiveness in case in which defendant debauched and impregnated adopted daughter and servant of plaintiff); Hewlett v. Cruchley, 128 Eng. Rep. 696 (1813) (denying new trial for excessive damages in a malicious prosecution case); Merest v. Harvey, 128 Eng. Rep. 761 (1814) (denying motion to set aside verdict for excessiveness in trespass case); Edgell v. Francis, 133 Eng. Rep. 314, 316 
After the adoption of the Seventh Amendment, in only a few cases did courts grant new trials for excessive damages in cases in which damages were uncertain. Given the extensive authority against the grant of such new trials, this practice of a few courts should not be a "rule of the common law."234 Moreover, the occurrence of these cases after the Seventh Amendment's adoption also dictates that minimum weight be given them. ${ }^{235}$

In the cases regarding motions for excessive damages, English courts have stated or implied that judges may not set damages on their own and that the jury is the proper determiner of the damages. In the pre-Seventh Amendment case of Leeman v. Allen, 236 decided in 1763, the Chief Justice of the King's Bench, in denying a motion for a new trial for excessive damages, specifically stated that in

(1840) (in denying new trial for excessiveness in trespass and false imprisonment case, one judge stated: "The amount of damages is a question for the jury."); Creed v. Fisher, 156 Eng. Rep. 202, 203 (1854) (" $[I] t$ is the peculiar province of the jury to assess the damages, and... the Court ought not to interfere, unless it be very manifest that the jury have so misconducted themselves."); Williams v. Currie, 135 Eng. Rep. 774, 777 (1845) (denying new trial for excessive damages in trespass case and stating: "In cases of this sort, it is not to be expected that a jury will measure their verdict so nicely as in cases of contract; and therefore it is exceedingly difficult for the court to draw the line at which their interference ought to stop."); Praed v. Graham, 24 Q.B.D. 53 (1889) (affirming denial of new trial for excessive damages in a libel case).

Around the time of the adoption of the Seventh Amendment, courts also decided motions for new trials based on inadequate damages. See Markham v. Middleton, 93 Eng. Rep. 1167 (1746) (permitting new writ of inquiry where the jury awarded one penny damages to plaintiff when defendant owed plaintiff $£ 333$ for an apothecary's bill); Barker v. Dixie, 95 Eng. Rep. 180,181 (1736) (denying new trial motion for inadequate damages in malicious prosecution case, explaining that "in torts the damages are uncertain always, and the language of the law is, that the jury are judges of damages"); Hayward \& Newton, 94 Eng. Rep. 432 (1732) (denying new trial for smallness of damages in action of words case); Phillips v. London \& S.W. Ry. Co., 5 Q.B.D. 78 (1879) (affirming decision of Queen's Bench to grant new trial for inadequate damages in negligence action).

234 See supra text accompanying notes 150-51. In one case, ordering a new trial for excessive damages in an assault and false imprisonment case, one justice of the Court of Common Pleas, specifically stated that: "We are not doing away with juries by ordering a new trial, but only sending the case to another jury." Price v. Severn, 131 Eng. Rep. 122, 123 (1831). In another case, the King's Bench granted a new trial for excessive damages in a peculiar assault and battery case. See Jones v. Sparrow, 101 Eng. Rep. 144, 144 (1793). There, the plaintiff, who was the servant of the defendant master, was awarded damages by the jury after receiving a "slight blow... [for] impertinent behaviour" from the master. Id. at 144 . The plaintiff had responded by "violently beat[ing]" the master-defendant after receiving the slight blow. Id.

One justice in Price also stated that the court would generally suggest to the parties that they settle a case in which excessive damages had been given to prevent a new trial. See 131 Eng. Rep. at 123. The justice did not state, however, that the court would ever suggest an amount.

235 See supra text accompanying notes 145-51.

23695 Eng. Rep. 742 (1763). 
tort cases, "the Court must be able to say the damages are beyond all measure unreasonable, though they cannot say exactly what damages ought to be given."237 There is similar language in some cases after the adoption of the Seventh Amendment. For example, in Duberley v. Gunning, ${ }^{238}$ decided in 1792, although the King's Bench acknowledged that they might not have awarded such large damages to the plaintiff, a new trial had never been awarded for excessive damages in an action for criminal conversation. ${ }^{239}$ The Justices emphasized that there was no standard by which to ascertain the excess and that their judgment should not be taken over that of the jury. ${ }^{240}$ One Justice stated "[a]ccording to my judgment of this case, I think the damages are a great deal too much, . . . but as the jury have formed a different judgment upon the evidence, I know not why my judgment should be preferred to theirs upon such a subject." 241 Another Justice observed "[w]e have no right in such a case to set up our own judgment against that of the jury, to which the constitution has referred the decision of the question of damages." 242

237 Id. at 743 (emphasis added). In the seventeenth century case of Townsend $v$. Hughes, 86 Eng. Rep. 994 (1667), denying a motion for a new trial for excessive damages in a slander case, the Chief Justice stated he could not "lessen the sum or grant a new trial, especially since by the law the jury are judges of the damages." Id. at 994-95. One judge, although disagreeing with the other three that a new trial for excessiveness could not be granted, agreed that "it is true, they cannot lessen the damages, but if they are too great the Court may grant a new trial." Id. at 995 .

238100 Eng. Rep. 1226 (1792).

239 Id. at $1227-28$.

240 Id. at $1228-29$.

241 Id. at 1228.

242 Id. While the dissenting Justice Buller stated that a new trial should be granted, he emphasized that the Court was "wrong[,] . . taking upon themselves to determine the exact amount of what the damages ought to have been, which is clearly the province of the jury to decide." Id. at 1229. He also stated that the new jury would be given free rein to award the amount of damages unrestrained by the justices' opinion of the case. See id:; see also Watson v. Christie, 126 Eng. Rep. 1248 (1800) (denying new trial for excessive damages in trespass case); Hewlett v. Cruchley, 128 Eng. Rep. 696 (1813). Notably, as late as 1879, in affirming a grant of a new trial for inadequate damages, the Court of Appeal stated: "[T] unreasonably small, to what extent of course we must not speculate, and have no business to say. We are, therefore, of opinion that the Queen's Bench Division was right in directing a new trial." Phillips v. London \& S.W. Ry. Co., 5 Q.B.D. 78, 86 (1879) (emphasis added). Regarding the standard for ordering a new trial, the Court had stressed that:

We agree that judges have no right to overrule the verdict of a jury as to the amount of damages, merely because they take a different view, and think that if they had been the jury they would have given more or would have given less, still the verdicts of juries as to the amount of damages are subject, and must, for the sake of justice, be subject, to the supervision of a Court of first instance, and if necessary of a Court of Appeal in this way, that is to say, if in the judgment of the Court the damages are unreasonably large or 
Courts even refused to determine the damages in cases in which an advisory jury rendered excessive damages. ${ }^{243}$ The Chief Baron of the Court of Exchequer in 1796 emphasized that "[w] cannot say what the damages ought to be, but can only send it for the investigation of another jury."244

These cases further demonstrate that remittitur as practiced today in the federal courts did not exist at English common law in 1791. If it had existed, courts would have mentioned the alternative of a reduction in the damages in ordering new trials. There is no such mention in any of the cases found. Instead, courts emphasized that only juries could determine damages and that ordering a new trial was the most that a court could do. In the immediate time period before the Seventh Amendment's adoption, even orders for new trials were rare and never occurred in cases in which damages were uncertain. ${ }^{245}$ As a corollary point, this suggests that new trials for excessive uncertain damages are unconstitutional because such re-examination of uncertain damages did not exist under the common law. ${ }^{246}$

These new trial cases are even more interesting when viewed in the context that under the English common law, only en banc courts of four judges decided motions for new trials. ${ }^{247}$ At that time, unlike now in the federal courts, one judge could not overrule the jury's factual determination of damages.

As shown here, at English common law, the plaintiff proactively used "remittitur" to cure some defect in the record that could cause him to have to submit to a new trial or to replead his case entirely. ${ }^{248}$ Moreover, English courts

unreasonably small then the Court is bound to send the matter for reconsideration by another jury.

Id. at 85-86 (emphasis added).

243 See supra text accompanying notes 183-86.

244 Goldsmith v. Sefton, 145 Eng. Rep. 1046, 1046 (1796) (emphasis added). In Bruce v. Rawlins, 95 Eng. Rep. 934 (1770), the Chief Justice of the King's Bench stated while it was in their power to order such a new writ of inquiry because a writ of inquiry was only "an inquest of office to inform the conscience of the Court, who, if they please, may themselves assess the damages," no new writ of inquiry would be awarded in this trespass case. Id. at 934. But see supra note 183.

245 See supra notes $227-33$ and accompanying text.

246 See infra text accompanying notes 261-63.

247 Dimick v. Schiedt, 293 U.S. 474, 492 n.2 (1935) (Stone, J., dissenting); Dagnello v. Long Island R.R. Co., 289 F.2d 797, 803-04 (2d Cir. 1961) (Dagnello assumes, using Dimick as support, that trial judges could not order remittitur on their own); Lettow, supra note 183, at 525; Austin Wakeman Scott, Trial by Jury and the Reform of Civil Procedure, 21 HARv. L. REV. 669, 682 (1918). There is some disagreement as to whether a new trial could be granted only if the nisi prius (lower court) judge agreed with the other judges. See Gasperini v. Ctr. for Humanities, Inc., 518 U.S. 415, 456-57 (1996) (Scalia, J., dissenting).

248 In only one case reviewed, which was decided after the Seventh Amendment's adoption, did a defendant request that the court enter a remittitur to cure an erroneous judgment. $\mathrm{He}$ apparently did so to deny the plaintiff recovery against him in the future. The court denied 
specifically disclaimed a power to reduce jury verdicts. Further, courts could not reduce verdicts with the consent of only one party and courts did not state the maximum sum that a reasonable jury could find. Additionally, in cases reporting motions for new trials for excessive damages, no mention is made of an alternative option for the judge to reduce the verdict. Accordingly, the federal courts practice a "remittitur" that finds no analogue at English common law in 1791. Thus under a static reading of the common law as tied to 1791 English practice, remittitur is unconstitutional.

\section{Remittitur Under Early American Common Law}

While the Supreme Court has stated that the English practice in 1791 governs what constitutes "the rules of the common law" under the Seventh Amendment, state and federal law in the 1791 time period has never had the same influence. An examination of the state and federal law in the 1791 period provides, however, additional support for the importance of the English common law and the conclusion that remittitur is unconstitutional. ${ }^{249}$ Around the time of the adoption of the Seventh Amendment, "remittitur" in the state and federal courts was, like under the English common law, a procedure used by plaintiffs to cure defects in the pleadings. ${ }^{250}$ Moreover, in this time period the state and federal courts adhered to the English common law rule regarding new trials for excessive

the defendant's request stating "there is no authority for dividing a judgment in this way without the consent of the plaintiff." Philips v. Jones, 117 Eng. Rep. 683, 686 (1850).

249 See supra notes 92-144 and accompanying text; cf. supra note 137.

250 See President of the Bank of Ky. v. Ashley, 27 U.S. (2 Pet.) 327, 328-29 (1829) (citing English rules and permitting remittitur of excess over declaration); Davenport $v$. Bradley, 4 Conn. 309, 311, 1822 WL 32, at $* 2$ (Conn. 1822) (finding that plaintiff cannot recover more than damages in declaration and must remit excess before judgment); Stephens v. White, 2 Va. (2 Wash.) 203, 212, 1796 WL 649, at *8 (Va. 1796) (deciding that plaintiff can remit excess of damages in declaration); Harris v. Jaffray, 3 H. \& J. 543, 546, 1815 WL 271, at *3 (Md. 1815) (deciding that plaintiff may remit excess of damages set forth in declaration); Johnson v. Van Doren, 2 N.J.L. 374, 374, 1808 WL 942, at *1 (N.J. 1808) (stating that plaintiff must remit excess of demand before judgment); Curtiss v. Lawrence, 17 Johns. 111, 111, 1819 WL 1628 (N.Y. Sup. Ct. 1819) (same); Singleton v. Kennedy, 1 N.C. 629 (N.C. 1804) (stating that plaintiff may remit surplus upon payment of costs of writ of error); Fury v. Stone, 2 U.S. (2 Dall.) 184, 184 (Pa. 1792) (allowing plaintiff to remit excess of damages in declaration upon payment of costs of writ of error); Mooney v. Welsh, 8 S.C.L. (1 Mill) 133, 135-36, 1817 WL 598, at *2 (Const. 1817) (same); Hutchinson v. Crossen, 10 Mass. 251, 253, 1813 WL 874, at *3 (Mass. 1813) (stating that plaintiff may remit excess of amount declared); Hoit v. Molony, 2 N.H. 322, 323, 1821 WL 443, at *2 (N.H. 1821) (same); see also Newlin v. Palmer, 11 Serg. \& Rawle 98, 100, 1824 WL 2331, at *3 (Pa. 1824) (citing Duppa v. Mayo, 85 Eng. Rep. 366 (1670), and Ingledew v. Crips, 92 Eng. Rep. 43 (1702), and discussing remittitur of amount declared); Halsey v. Woodruff, 26 Mass. (9 Pick.) 555, 555-56, 1830 WL 2573, at *1 (1830) (remitting damages in action against two defendants). 
damages, particularly with respect to uncertain damages. ${ }^{251}$ Specifically, at the time of the adoption of the Amendment there were no cases in which a court

251 See Lettow, supra note 183, at 547-53. At the time of the adoption of the Seventh Amendment, the states in the union were: Connecticut, Maryland, New Jersey, New York, North Carolina, Pennsylvania, South Carolina, Rhode Island, Virginia, Delaware, Georgia, Massachusetts, and New Hampshire. There were no relevant published cases on the new trial for excessive damages from Maryland, Rhode Island, and Georgia around the time of the Seventh Amendment's adoption. Note that in some states the only published cases on the issue of new trials for excessive damages were after the adoption of the Seventh Amendment. See Cowperthwaite v. Jones, 2 U.S. (2 Dall.) 55, 56 (Pa. Ct. Com. Pl. 1790). In Cowperthwaite, in denying a new trial, the court stated:

[I] $[\mathrm{t}]$ orts and other cases, where there is no ascertained demand, it can seldom happen that jurymen will, at once, agree upon a precise sum to be given, in damages; there will necessarily arise a variety of opinions, and mutual concessions must be expected; a middle sum may, in many cases, be a good rule; and though, it is possible, this mode may sometimes be abused by a designing juryman, fixing upon an extravagantly high, or low sum, yet unless such abuse appears, the fraudulent design will not be presumed.

2 U.S. at 56; see also Roberts v. Swift, 1 Yeates 209, 212, 1793 WL 584, at *4 (Pa. 1793) (concluding in an assumpsit action that "[t]he damages are liberal, but not so outrageous as to justify the interposition of the court, in ordering a new trial"); Kuhn v. North, 10 Serg. \& Rawle 399, 410-11, 1823 WL 2286, at *11-12 (Pa. 1823) (denying new trial and citing English case of Huckle v. Money); Fuld v. Thompson, 1 Del. Cas. 393, 394, 1796 WL 422, at *1 (Del. Ct. Com. Pl. 1796) (stating in a trespass case that "the action being for a tort the Court could not set aside the verdict on the ground of excessive damages"); Neal v. Lewis, 2 S.C.L. (2 Bay) 204, 206, 1798 WL 245, at *2 (Const. 1798) (denying new trial in slander case, stating: "Shall this court, therefore, take upon themselves to say, that 3,000 dollars for such gross slanders were unreasonable or outrageous damages? They have no such power. It was for the jury to determine upon that point, and they have done so."); Tillotson v. Cheetham, 2 Johns. 63, 74, 1806 WL 949 (N.Y. Sup. Ct. 1806) (denying new writ of inquiry in slander case and stating "[w]e have no standard by which we can measure the just amount, and ascertain the excess"); Coleman v. Southwick, 9 Johns. 45, 51-53, 1812 WL 989, at *5-6 (N.Y. Sup. Ct. 1812) (citing English common law cases of, inter alia, Hawkins v. Sciet and Roe v. Hawkes, and denying new trial in libel case); Southwick v. Stevens, 10 Johns. 443, 446, 1813 WL 1098, at *4 (N.Y. Sup. Ct. 1813) ("It was for the jury to determine how far the ridicule of the plaintiff was malevolent, and calculated to injure his feelings, or prejudice him in the eyes of the public."); Deacon v. Allen, 4 N.J.L. 338, 340-41, 1816 WL 890, at *3 (N.J. 1816) (denying motion for new trial because damages in tort case not "so outrageous" to show prejudice by jury). In Ogden v. Gibbons, 5 N.J.L. 518, 1819 WL 3 (N.J. 1819), a trespass case, the court denied a new trial, stating:

[T] his is a case most decisively within the province of the jury. It is not simply and alone a case for a tort done to property, the value of which may be ascertained by evidence, and where there are fixed rules and principles to measure the damages; but it is one of character, of sentiment, of feeling; one where the court is not entrusted with the power to estimate the wrong, but the jury must exercise their discretion; a case depending much on the situation and circumstances, as well of the party injured, as of him who did the injury.

5 N.J.L. at 537-38, 1819 WL 3, at *12; see also Coffin v. Coffin, 4 Mass. (1 Tyng) 1, 41-44, 1808 WL 1037, at **30-32 (Mass. 1808) (denying new trial, citing English cases of, inter alia, 
granted a new trial for excessiveness in a case of uncertain damages. Also like the English common law courts, the state and federal courts in the immediate time period surrounding the Seventh Amendment's adoption made no mention of an alternative reduction of the damages by the court. ${ }^{252}$ The state and federal common law in the time period surrounding the adoption of the Seventh Amendment thus lead back to the English common law and the conclusion that remittitur as practiced by the federal courts is unconstitutional. ${ }^{253}$

\section{The Unconstitutionality of Remittitur Under an Evolving Common Law}

At common law, contrary to today's federal practice, judges did not remit damages as an alternative to a new trial for excessive damages, and as a result, remittitur is unconstitutional. Even if the focus shifts from a view of the common

Beardmore and Wilford, and stating that "[i]t is not the province of the Court to advise either party" as to the "reasonable" damages); Swann v. Bowie, 23 F. Cas. 504, 505 (C.C.D.C. 1820) (No. 13,672) (denying new trial for excessiveness in trespass case and stating "[i]n cases of tort, courts have seldom granted new trials unless the damages are so excessive as to imply gross partiality or corruption on the part of the jury"). But see M'Connell v. Hampton, 12 Johns. 234, 235-38, 1815 WL 1058 (N.Y. Sup. Ct. 1815) (granting new trial in assault and false imprisonment case, citing the few English common law cases in which a new trial was granted in a tort case); Harton v. Reavis, 4 N.C. $256,256-57,1815$ WL 1201, at **1-2 (N.C. 1815) (discussing Beardmore and Duberley but granting new trial for excessive damages in slander case).

252 See supra note 250; Clark v. Russell, 2 Day 112, 115, 1805 WL 195, at *3 (Conn. 1805) (stating new trial is "remedy" for excessive damages); Hague v. Stratton, 8 Va. 84, 1786 WL 85, at *1 (Va. 1786) (same); Eastwick v. Hugg, 1 U.S. (1 Dall.) 222, 224 (Pa. Ct. Com. Pl. 1787) (same); Estill v. Blakemore, 8 F. Cas. 798, 798 (C.C.D. Tenn. 1808) (No. 4538) (denying new trial for excessiveness in breach of covenant case); Letcher v. Woodson, $15 \mathrm{~F}$. Cas. 401 (C.C.D. Va. 1811) (No. 8280) (denying new trial for excessiveness in breach of covenant case).

The only evidence of an altemative remittitur by courts of damages awarded by a jury are in a few sporadic cases after 1815 in which courts reduced damages as a matter of law. Thus, those cases arguably are not the common law in 1791 and are also distinguishable as involving a legal issue. See Evertsen v. Sawyer, 2 Wend. 507, 510, 1829 WL 2316, at *4 (N.Y. Sup. Ct. 1829) (requiring no new trial if plaintiff takes three months less rent than awarded); Guerry v. Kerton, 31 S.C.L. (2 Rich.) 507, 512, 1846 WL 2233, at *3 (Ct. App. 1846) (stating that plaintiff could accept alternative reduction of damages to highest possible price of "negroes" instead of new trial for excessive damages); Doyle v. Dixon, 97 Mass. 208, 213, 1867 WL 5588, at *5 (Mass. 1867) (permitting alternative remittitur of damages in contract case); Pope v. Barrett, 19 F. Cas. 1018, 1021 (Mass. C.C.D. 1816) (No. 11,273) (allowing plaintiff in assumpsit action, as alternative to new trial, to remit certain damages not allowable in any case, and other damages awarded because jury did not follow instructions).

253 At the time of the adoption of the Seventh Amendment, "there were no states in the union, the basis of whose jurisprudence was not essentially that of the common law in its widest meaning; and probably no states were contemplated, in which it would not exist." Parsons v. Bedford, 28 U.S. (3 Pet.) 433, 446 (1830). 
law as static to a view of the common law that is more flexible or "evolving," the practice of remittitur remains unconstitutional.

An approach to the common law as evolving focuses on whether a questioned practice expands and does not contract the right to a jury trial. Or put another way, remittitur is constitutional if it preserves the role of the jury as factfinder as it functioned at common law. ${ }^{254}$ At common law, upon a finding that the jury rendered excessive damages, a plaintiff was given a new trial. The facts and the data presented at the beginning of this article suggest in fact that under remittitur in the federal courts, the plaintiff now lacks a real option to take the new trial, unlike at common law. ${ }^{255}$ The judge has stated the maximum amount that a reasonable jury could award and there is little opportunity to appeal this decision. Indeed, the study shows that the plaintiffs took the remittitur or settled in $98 \%$ of the cases and took the new trial in only $2 \%$ of the cases. This indicates that the practice of remittitur does not preserve the jury's role as fact-finder, and accordingly, remittitur is unconstitutional. Again, this does not take into account the additional fact that a plaintiff may settle before trial because the judge has remitted other jury verdicts.

One response to this conclusion of unconstitutionality may be that even if remittitur did not exist at common law, and regardless of these facts and data, at common law, judges granted new trials for excessive damages. Because such new trials were permissible at common law, a plaintiff today who is given the option of a remittitur is no worse off than a plaintiff back then. Under this argument, a plaintiff now is better off because he has the option of taking the remitted amount, instead of retrying the case.

Although this argument may sound logical, it fails to properly consider that, as practiced today, the judge remitting the verdict renders an opinion as to the greatest amount that a reasonable jury could have awarded. This powerful statement by the judge changes the nature of any new trial as well as the settlement posture of the parties. Indeed, now the plaintiff (who will present essentially the same evidence as presented in the first trial) ${ }^{256}$ has an imposing decision against him that declares the maximum amount that a reasonable jury could award under the evidence presented. Regardless of whether the presiding judge, the same judge who decided the motion, would again reduce a second verdict that was greater than the remitted amount, the plaintiff has no reason to believe otherwise and thus will accept the remittitur or settle the case. 257

254 See supra notes $141-44$ and accompanying text.

255 See supra notes 34-64 and accompanying text.

256 See supra notes 41-44 and accompanying text.

257 See supra notes $41-46$ and accompanying text. Another factor which influences the plaintiff's decision whether to take the new trial is on what issues the judge orders a new trial. The judge can order a new trial on liability and damages, on all damages or on only the category of damages that was remitted. See 11 WRIGHT ET AL., supra note 25, $\$ 2815$, at 159; see, e.g., Carter v. Rosenberg \& Estis, No. 95 CIv. 10439, 1998 WL 150491, at *25 (S.D.N.Y. 
Mar. 31, 1998) (ordering new trial on liability and damages if plaintiff did not accept remittitur of her compensatory damages award); Leather v. Ten Eyck, 97 F. Supp. 2d 482, 490-91 (S.D.N.Y. 2000) (ordering remittitur of punitive damages award but stating that if plaintiff did not accept that award, court would order new trial on both compensatory and punitive damages awards); McIntosh v. Irving Trust Co., 887 F. Supp. 662, 664, 669 (S.D.N.Y. 1995) (ordering new trial on compensatory damages if plaintiff did not accept remitted compensatory damages amount). Additionally, where a judge remits two damages awards, the plaintiff may be required to accept the remitted amount of both, not just one, or face a new trial on both damages awards. See, e.g., Ortiz-Del Valle v. Nat'l Basketball Ass'n, 42 F. Supp. 2d 334, 347 (S.D.N.Y. 1999). If the judge orders a new trial on liability and damages, there is little to no incentive to take the new trial. A plaintiff must give up everything for a chance that he will be awarded nothing, the same, or more than before, only to very possibly have the verdict again remitted by the trial court.

Although the fact that a federal judge may order a new trial on liability and damages may influence a plaintiff's decision not to take the new trial, this is not conclusive to show remittitur is unconstitutional. Up until the early twentieth century whole new trials were granted for excessive verdicts. With that said, it is certainly persuasive that once a new trial has been granted, in only rare cases should a new trial be granted on more than the damages that were remitted. In Gasoline Products Co. v. Champlin Refining Co., 283 U.S. 494 (1931), the Supreme Court decided that the Seventh Amendment was not violated by a new trial on damages only. Id. at 498-99; see also Wagner, supra note 16, at 646 . Although the practice in 1791 when the Amendment was adopted, a new trial on liability and damages is not required under the Seventh Amendment. See Gasoline Prods. Co., 283 U.S. at 498-99; see also supra text accompanying notes 123-24. In Simmons v. Fish, 97 N.E. 102 (Mass. 1912), cited in Gasoline Products, the highest court in Massachusetts, in granting a new trial on damages only, quoted another case which stated:

The guiding principle is that, although a verdict ought not to stand which is tainted with illegality, there ought to be but one fair trial upon any issue, and that parties ought not to be compelled to try anew a question once disposed of by a decision against which no illegality can be shown.

Id. at 104; see also Norfolk S.R.R. Co. v. Ferebee, 238 U.S. 269, 272-74 (1915) (stating general rule that a partial new trial was appropriate only if "the matter involved is entirely distinct and separable from the other matters involved in the other issues and... that no possible injustice can be done to either party." (quoting Jarrett v. High Point Truck \& Bag Co., 144 N.C. 299,302 , 56 S.E. 937 (1907))). In that case, the special verdict form appears to have helped the court determine what the jury found. See Norfolk S.R.R. Co., 238 U.S. at 272-74; see also Simon v. Philip Morris, Inc., 200 F.R.D. 21, 24 (E.D.N.Y. 2001) (stating that 'the Seventh Amendment is only implicated where a severed issue is presented to a subsequent jury in a confusing or uncertain manner"). In many if not all cases, a retrial of damages issues will necessarily require hearing at least some evidence regarding liability. See Ace v. Aetna Life Ins. Co., 40 F. Supp. 2d 1125, 1136 (D. Alaska 1999) (granting new trial on punitive damages although everything in case related to punitive damages and there would be no significant time savings); see also Morrison Knudsen Corp. v. Fireman's Fund Ins. Co., 175 F.3d 1221, 1256 (10th Cir. 1999) (showing no hesitancy "to find damages to be a distinct and separable issue"). This fact, however, does not necessitate a new liability finding, rather it would involve a longer trial, which would also occur upon a new trial of liability and damages. See also FED. R. CIV. P. 56(c), (d) (stating that summary judgment may result in separate trial on damages); FED. R. CIV. P. 42(b) (permitting a court to order separate trials on separate issues). Tort, discrimination and 
Without the judge-determined maximum figure, there is no maximum amount that effectively limits the second jury. A plaintiff could very well then take the new trial with the knowledge that he could receive more or the same as previously awarded. Indeed, if a second jury awarded the same or more than the first jury, it would be difficult for a judge to say both juries had been unreasonable. ${ }^{258}$ The parties may still decide to settle the case, but the settlement amount would be based on a compromise between the parties, not based on a judge-determined reasonable figure. 259

In addition to eliminating the plaintiff's right to a jury trial on damages, the practice of remittitur may cause judges to order more new trials for excessive

personal injury cases, among others, have provided a basis for severing liability issues from damages. See Simon, 200 F.R.D. at 31-32.

258 Blackstone stated that "if two juries agree in the same or a similar verdict, a third trial is seldom awarded: for the law will not readily suppose, that the verdict of any one subsequent jury can countervail the oaths of two preceding ones." 3 BLACKSTONE, supra note 179, at 387; see also supra note 226.

${ }^{259}$ One of the cases in the study illustrates the nature of remittitur such that plaintiff's right to a jury trial on damages is effectively eliminated. See Lightfoot v. Union Carbide Corp., No. 92 CIV 6411, 1997 WL 543076 (S.D.N.Y. Sept. 4, 1997). In this age discrimination case, the jury awarded $\$ 750,000$ in compensatory damages. Lightfoot v. Union Carbide Corp., $901 \mathrm{~F}$. Supp. 166, 167 (S.D.N.Y. 1995). Upon a motion for a new trial or alternatively a remittitur, the court granted a remittitur of the jury award to $\$ 75,000$ without the option of a new trial. See id. at 169-70. After the Second Circuit reversed and stated that the judge must give plaintiff the option of a new trial, the judge held a pre-trial conference with the parties. The court

urged the parties to settle the matter. When defendant indicated it would be unwilling to settle for much more than $\$ 75,000$ plus litigation costs, plaintiff indicated this was insufficient. In response to this comment of plaintiff's, [the court] suggested that plaintiff should bear in mind [the judge's] prior remittitur in assessing the wisdom of trying the case again. [The judge] noted [his] view that, based on the evidence presented at the first trial, plaintiff did not suffer more than $\$ 75,000$ in damages.

Lightfoot, 1997 WL 543076, at *1 (on remand). These comments made by the judge at the pretrial conference suggested, if not directly conveyed, that plaintiff should not retry the case because the judge would remit any damages awarded in the second trial greater than the remitted amount. In the opinion denying a motion for recusal, the judge "explained" that the evidence in the second trial would be different than presented in the first case, even if the parties called the same witnesses. See id. at *2. As a result, it would be possible for him upon a new trial to sustain a verdict greater than $\$ 75,000$. See id. Regardless of the judge's attempt to show that he would not inevitably reduce a second verdict if it was greater than $\$ 75,000$, the judge, by his comments at the required pre-trial conference, had told plaintiff in no uncertain words that he could expect the same remitted result after a second trial. This case shows how the remitted amount can be used to attempt to obtain plaintiff's acceptance of the remittitur or a settlement near the remitted amount. Despite the judge's warming, this was one of the few cases in the study where the plaintiff took the new trial. See supra note 58 Upon the second trial, the jury awarded $\$ 20,000$ and the plaintiff's subsequent appeals were unsuccessful. See Lightfoot v. Union Carbide Co., 175 F.3d 1008 (2d Cir. 1999). 
damages. ${ }^{260}$ The judge is likely to know that the plaintiff will not take the new trial if, as an alternative to the new trial, the judge announces the maximum reasonable remitted verdict. Because the plaintiff is unlikely to take the new trial, a judge can precipitate an end to the litigation by ordering a new trial and an alternative remittitur. If remittitur were eliminated, the plaintiff would have a real opportunity to retry his case, and as a result, it is likely that there would be more new trials. Accordingly, because such new trials would add to the already crowded federal court docket, judges may not in fact order as many new trials for excessive damages if they could not order the alternative remittitur.

The study also demonstrated that, contrary to the English common law where courts did not interfere with uncertain damages, ${ }^{261}$ federal judges use remittitur in cases which include uncertain damages, including in many cases, emotional distress damages, and often in civil rights cases. Sixty-eight percent of the remittiturs were ordered in cases involving uncertain damages. At a minimum this shows that judges have invaded the common law province of the jury as the determiner of uncertain damages. Moreover, a judge-determination of what is reasonable compensation, for example, for a person's emotional harm, could very well differ from a six- to twelve-person jury determination of the damages suffered. Judges and juries could also have very different views of the damages in civil rights cases, where $42 \%$ of the remittiturs in the study occurred. A judge's and jury's conclusions may come from incommensurable perspectives and experiences, neither of which make the judge or the jury unreasonable. ${ }^{262}$

The use of remittitur in these areas where it is plausible for different people to have different views of the damages, illustrates how far from the English common law the federal courts have wandered. This re-examination of a jury's findings on subjective damages is an example of what the re-examination clause was designed to prevent - the substitution of a judge's determination of the damages

260 This hypothesis could be roughly tested if there was a state with remittitur and a state without remittitur, and the grant of new trials for excessive damages were compared. $C f$. Newsom, supra note 16, at 155, 160 (stating that remittitur and additur were developed to remedy the problems caused as "trials on other more substantive grounds crowded the courts" and the grant of new trials based on excessive or inadequate verdicts became necessary); Judicial Use of Additurs, supra note 16, at 667 (same); Correction of Damage Verdicts, supra note 16, at 318-19 (same). But see Dorsaneo, supra note 5, at 1728 (stating that remittitur is "considerably less intrusive" than treating damages as matter of law issue and is an "effective method for handling excessive verdicts").

261 See supra text accompanying notes 218-52; see, e.g., Honda Motor Co. v. Oberg, 512 U.S. 415, 447 (1994) (Ginsburg, J., dissenting); cf. Murphy, supra note 26, at 461 ("The option of a new trial-although inefficient and often rejected by plaintiffs in favor of remittitur-is integral to preserving the constitutional ideal that juries, rather than judges, are the principal decision makers on uncertain damages.").

262 See supra note 32; cf., e.g., Nancy S. Marder, Juries, Justice \& Multiculturism, $75 \mathrm{~S}$. CAL. L. REV. 659 (2002) (arguing diversity in jury may make difference in deliberations). 
for those of the jury. Such re-examination of facts runs counter to the preservation of the role of the jury as the fact-finder. ${ }^{263}$

In adopting a conception of the common law as evolving, the specifics of the practices which existed at common law do not control the constitutionality of modern practices. Nevertheless, under an evolving common law, the substance of the right to a jury trial must be maintained such that at minimum the jury is the fact-finder as it existed at English common law. Remittitur does not preserve that role for the jury. At common law, upon a grant of a new trial, a plaintiff would have an opportunity to try her case again. Remittitur, as shown by the data, leaves no room for a new trial and thus leaves no room to preserve the jury's role as the fact-finder. When a judge grants a remittitur, plaintiff effectively has no choice to take the new trial. The result will be the judge-determined amount or a settled, highly judge-influenced amount. Additionally, with the modern expansion of the new trial for excessive damages into cases involving uncertain damages, the right to a jury trial contracts. This in and of itself is unconstitutional. Moreover, then, with remittitur in this area, the first jury's determination as to the uncertain damages is set aside, and again the judge-remitted amount or judge-influenced settlement is substituted for the jury's damages determination. Because remittitur does not preserve the jury's role as fact-finder under the English common law, remittitur is unconstitutional under a conception of the common law as evolving.

\section{E. Remittitur and Stare Decisis}

Subsequent to Dimick, Supreme Court opinions have summarily endorsed the constitutionality of remittitur, citing Dimick. ${ }^{264}$ The Supreme Court has even encouraged remittitur, including upholding in Gasperini the right of an appellate court to re-examine facts by the review of a jury verdict after a trial court has denied a motion for a new trial. ${ }^{265}$ Further, in the recent case of Gebser v. Lago

263 One could argue that judges should review cases that involve uncertain damages as much or more than cases with certain damages because uncertain damages are subjective; if judges review such damages then a comparison can be made among the awards and consistency among the awards can be achieved. This argument ignores the difference between certain and uncertain damages. That is, uncertain damages are uncertain, not calculable with certainty. A "comparison" of facts among cases, while a doctrine created judicially in modem American decisions, does not necessarily reflect an accurate accounting of damages. Indeed, the English common law courts in the time period surrounding the Seventh Amendment and thereafter rejects any such view of uncertain damages and thus leaves such damages to the determination of the jury.

264 See, e.g., Hetzel v. Prince William County, 523 U.S. 208, 211 (1998); Gasperini v. Ctr. for Humanities, Inc., 518 U.S. 415, 433 (1996); Honda Motor Co., 512 U.S. at 444 n.10 (Ginsburg, J., dissenting) (stating that Dimick settled that remittitur is compatible with Seventh Amendment).

265 See Gasperini, 518 U.S. at 439. 
Vista Independent School District, ${ }^{266}$ Justice Stevens, joined in his dissent by Justices Souter, Ginsburg, and Breyer, stated that the power of courts to remit damages should assure the majority that any large damage awards by juries in Title IX cases would remain checked. ${ }^{267}$ These decisions and the decisions in the ten-year study show that remittitur is alive in the federal courts despite its "doubtful [constitutional] precedent." 268

The courts have misconstrued Dimick to have rendered a decision on the constitutionality of remittitur even though the remittitur discussion was only dicta and was not extended to the opinion that additur was unconstitutional. While this conclusion is novel, a close reading of Dimick dictates this conclusion. It follows that the constitutionality of remittitur is still an open question that should be determined in the manner that this article has set forth.

One might argue, however, that regardless of what the Court actually did in Dimick, the federal courts have deferred to Dimick as if it upholds the constitutionality of remittitur and that this "constructive" holding should be overruled only pursuant to an analysis applying stare decisis. Even accepting arguendo that the Court's commentary on remittitur implies a rule of law deserving of precedence, Dimick should be overruled. There were two premises in Dimick. First, some English common law courts used remittitur as practiced in the federal courts. Second, federal courts applied remittitur for over one hundred years. Both premises were wrong.

First, in reaching its "holding" on the constitutionality of remittitur, Dimick improperly emphasized some apparent English practice of remittitur. As shown in this article, "remittitur" at English common law in 1791 was a way by which the plaintiffs corrected errors in their pleadings, not a discretionary tool by judges to reduce verdicts. At English common law in 1791, courts disclaimed any power to reduce verdicts. Moreover, on motions for new trials for excessive damages, there was no option to accept a remittitur of the verdict determined by the court.

Moreover, Dimick's premise that federal courts had practiced remittitur for over one hundred years after the decision in Blunt in 1822 was greatly exaggerated. ${ }^{269}$ The first case in which a court actually applied remittitur came almost fifty years after Blunt. In 1871, in Russell v. Place, ${ }^{270}$ a circuit judge ordered remittitur of lost profit damages in a patent infringement case and cited no authority in support of his power to do so. ${ }^{271}$ From the late 1870s until 1935,

266524 U.S. 274 (1998).

267 See id. at 293, 302 n.12 (Stevens, J., dissenting).

268 See Dimick v. Schiedt, 293 U.S. 474, 485 (1935).

269 See 293 U.S. at 484; see also supra note 84 and accompanying text (Dimick cites Justice Story's circuit court decision in Blunt as the time when the federal courts began remitting verdicts).

27021 F. Cas. 57 (C.C.N.D.N.Y. 1871) (No. 12,161).

271 See id. In the fifty year time period after Blunt and before Russell, there was no application of remittitur by the federal courts and in fact almost no mention of remittitur. The 
when Dimick was decided, reports of federal remittitur became more frequent. Nevertheless, as shown here, for the first fifty years after Blunt, there was only one order of remittitur. This sporadic employment of remittitur by so few courts undermines Dimick's premise that remittitur had been utilized in federal courts for over one hundred years. ${ }^{272}$ Because both premises underlying the constitutionality analysis of remittitur in Dimick were false, no weight should be given Dimick based on a stare decisis analysis.

Additionally, using the Court's present stare decisis analysis, the constitutionality of remittitur should not be upheld. Recently, in Ring $v$. Arizona, ${ }^{273}$ overruling a decision under the Sixth Amendment, the Court stated "[a]lthough " "the doctrine of stare decisis is of fundamental importance to the rule of law[,]" ... [o]ur precedents are not sacrosanct. ... [W]e have overruled prior decisions where the necessity and propriety of doing so has been established.' "274 To decide whether a prior decision should be overruled, the Court tests "the consistency of overruling a prior decision with the ideal of the rule of law," and "gauge[s] the respective costs of reaffirming and overruling a prior case." 275 In this analysis, the court may look at

whether the rule has proven to be intolerable simply in defying practical workability; whether the rule is subject to a kind of reliance that would lend a special hardship to the consequences of overruling and add inequity to the cost of repudiation; whether related principles of law have so far developed as to have left the old rule no more than a remnant of abandoned doctrine; or whether facts have so changed, or come to be seen so differently, as to have robbed the old rule of significant application or justification. ${ }^{276}$

first mention came fourteen years after Blunt in a case decided again by Justice Story. See Wiggin v. Coffin, 29 F. Cas. 1157, 1161 (C.C.D. Me. 1836) (No. 17,624). In that malicious prosecution case, Justice Story felt it inappropriate to order an altemative remittitur but ordered a new trial for excessive damages. See id. The next mention of remittitur came another twentysix years later in 1862 , when another circuit justice, citing no authority, again mentioned the possibility of remittitur but refused to remit damages. See Johnson v. Root, 13 F. Cas. 798, 806 (C.C.D. Mass. 1862) (No. 7409).

272 The dissent in Dimick also incorrectly cites to the English practice of remittitur to correct pleadings in support of the use of remittitur to reduce jury verdicts. See 293 U.S. 474, 496-97 (1935) (Stone, J., dissenting).

273536 U.S. 584 (2002).

${ }^{274}$ Id. at 608 (quoting Patterson v. McLean Credit Union, 491 U.S. 164, 172 (1989) (quoting Welch v. Tex. Dep't of Highways \& Pub. Transp., 483 U.S. 468, 494 (1987))).

275 See Planned Parenthood v. Casey, 505 U.S. 833, 854 (1992).

276 See id. at 854-55 (citations omitted); cf. Richard H. Fallon, Jr., Stare Decisis and the Constitution: An Essay on Constitutional Methodology, 76 N.Y.U. L. REV. 570, 572 (2001) (suggesting stare decisis demands practical justification); Thomas R. Lee, Stare Decisis in Historical Perspective: From the Founding Era to the Rehnquist Court, 52 VAND. L. REV. 647, 684 (1999) ("[P]recedent may be susceptible to reversal if it is undermined (though not 
The federal courts have used remittitur for years so there is no issue of remittitur's workability nor the abandonment of the doctrine. As a result, those factors do not dictate overruling Dimick. One might argue, on the other hand, that to eliminate remittitur would be to lessen judicial efficiency. Upon defendants' motions for new trials for excessive damages, there may be significantly more trials. The parties may be less likely to settle cases on their own without the judge's determination of the maximum amount that a reasonable jury could award, and there would be no remitted amount for the plaintiff to accept.

Another way to look at this change is the number of new trials may not significantly increase. The parties may settle cases in which a judge grants the motion, based on their unwillingness to take a chance with another jury and bear the costs of another trial. Additionally, courts may order fewer new trials. ${ }^{277}$ Regardless of whether the unavailability of remittitur would result in significantly more new trials, Dimick should be overruled because the price of judicial efficiency cannot be the curtailment of a constitutional right.

Indeed, the ideal of the rule of law would be promoted by overruling the constitutionality of remittitur. Regardless of the Supreme Court's ambiguous reference in Dimick to some remittitur practice before the adoption of the Seventh Amendment, remittitur as practiced in the federal courts was not an established common law practice at the time of the adoption of the Seventh Amendment. Moreover, under an evolving common law, remittitur interferes with the jury's role as the fact-finder by the elimination of the plaintiff's right to a jury trial. Declaring remittitur unconstitutional would stop this curtailment of the plaintiff's right to a jury trial. 278

expressly overruled) by subsequent cases, or if it is premised on an incomplete factual record."); Michael Stokes Paulsen, Abrogating Stare Decisis by Statute: May Congress Remove the Precedential Effect of Roe and Casey?, 109 YALE L.J. 1535, 1546 (2000) ("[T]he Casey opinion confirms the view that respect for precedent does not imply an obligation to follow precedent."); Christopher J. Peters, Foolish Consistency: On Equality, Integrity, and Justice in Stare Decisis, 105 YALE L.J. 2031, $2044-47$ (1996) (noting that the Court's stare decisis analysis in Casey was consequentialist, focused exclusively on the practical implications of overruling Roe v. Wade and not on adherence to precedent as a legal end in itself).

277 See supra text accompanying notes 258-59. As shown above, under a static view of the common law, it is constitutionally required that judges should not (as they have in the federal courts) grant new trials for excessive damages in cases involving uncertain damages. See supra text accompanying notes 260-61.

278 As the Justices in Casey recognized, "stare decisis is not an 'inexorable command" ", particularly not in constitutional cases. See 505 U.S. at 854; $c f$. Beacon Theatres, Inc. v. Westover, 359 U.S. 500, 517 (1959) (Stewart, J., dissenting) (characterizing as a "marked departure from long-settled principles" the majority's decision to find unconstitutional under Seventh Amendment the lack of jury trial on original claim for equitable relief for which jury trial was possible for counterclaim). 


\section{CONCLUSION}

This article demonstrates that the Supreme Court should revisit the issue of the constitutionality of remittitur. The study of the English cases at the time of the Seventh Amendment's adoption shows that remittitur as presently practiced by the federal courts did not exist at common law in 1791. Thus, under the traditional view of the rules of the common law in the re-examination clause, remittitur is unconstitutional. Moreover, regardless of whether this static view of the reexamination clause is accepted, a conception of the common law as evolving necessarily involves an expansion and not a contraction of the jury trial right.

The practice of remittitur contracts the right to a jury trial by effectively eliminating the jury's fact-finding on damages. When the judge declares the maximum damages that a jury could find under the facts, there is no reason for the plaintiff to take the new trial. The judge has offered the remitted amount, the most that the plaintiff could receive in damages upon a new trial.

The case study of remittitur by federal courts over a ten-year period indeed demonstrates that remittitur effectively eliminates the plaintiff's right to a jury trial on damages: the plaintiffs take the remittitur or settle in $98 \%$ of the cases in which a judge grants a remittitur. Remittitur leaves no real option for the plaintiff to take the new trial. Thus, even under an evolving common law, remittitur is unconstitutional.

At common law, four judges decided the motion for a new trial for excessive damages. Moreover, judges found excessive only damages that were certain. Now a change has occurred such that lone judges review for excessiveness cases of uncertain damages, including civil rights cases, with little possibility of judicial review. With the addition of remittitur, judges exercise even more power than existed at common law. Courts impose legislative-type caps on cases with uncertain damages, again with little possibility of further review. If the Seventh Amendment and specifically the re-examination clause is to have meaning, the Supreme Court must review the practice of remittitur and find it unconstitutional. 


\begin{tabular}{|c|c|c|c|c|c|c|c|c|}
\hline 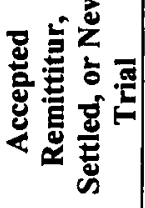 & 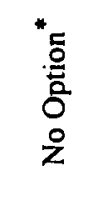 & 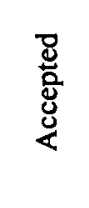 & 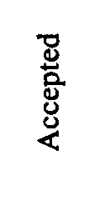 & $\begin{array}{l}\mathbb{Z} \\
\stackrel{0}{0} \\
\stackrel{8}{8} \\
\&\end{array}$ & 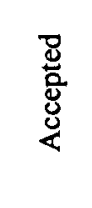 & 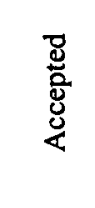 & 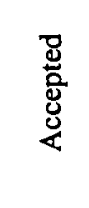 & 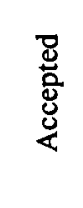 \\
\hline 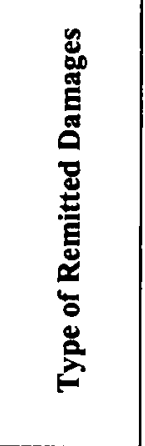 & 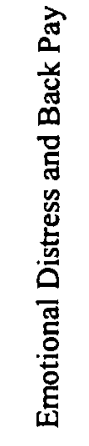 & 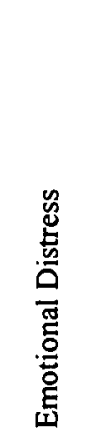 & 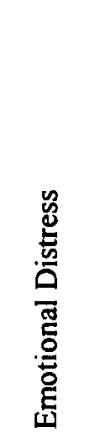 & 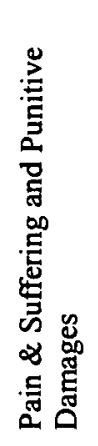 & 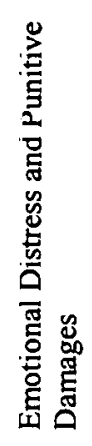 & 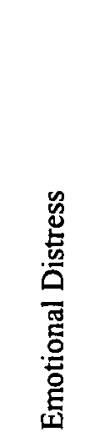 & 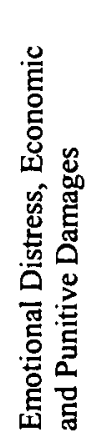 & 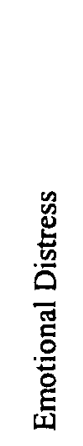 \\
\hline 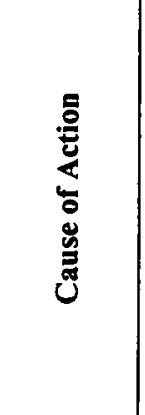 & 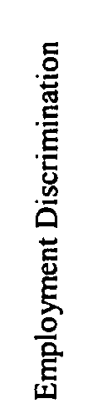 & 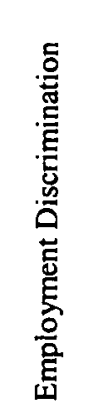 & 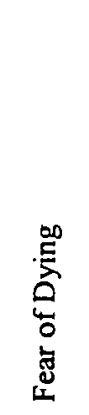 & 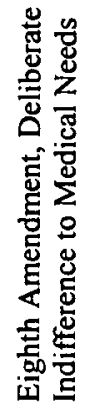 & 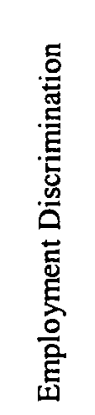 & 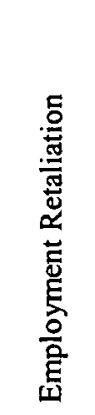 & $\frac{\infty}{\infty}$ & 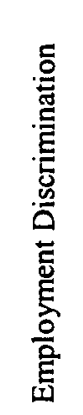 \\
\hline & 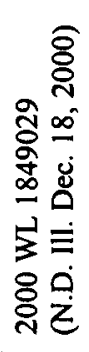 & 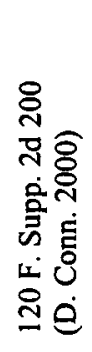 & 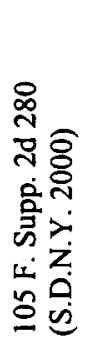 & 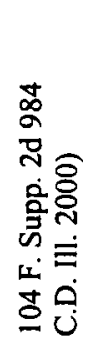 & 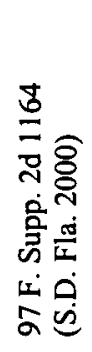 & 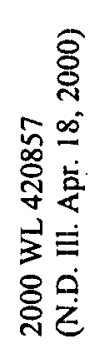 & 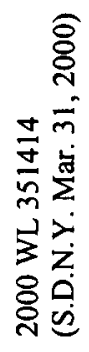 & 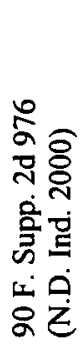 \\
\hline$\underset{\tilde{U}}{\tilde{U}}$ & 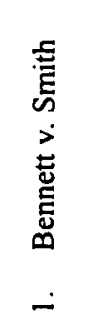 & 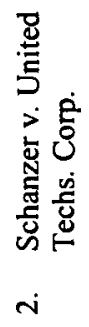 & 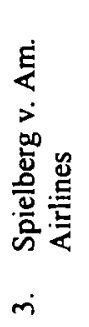 & 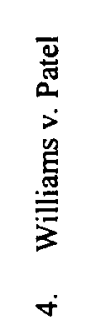 & 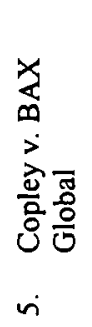 & 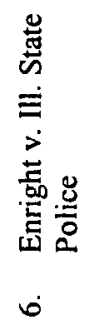 & 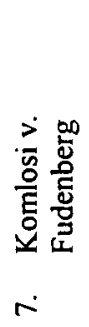 & 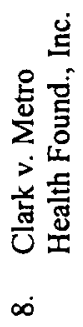 \\
\hline
\end{tabular}




\begin{tabular}{|c|c|c|c|c|c|c|c|}
\hline 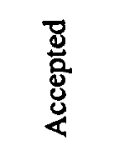 & 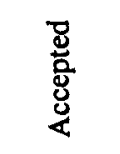 & 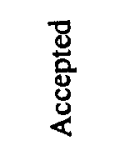 & $\begin{array}{l}\frac{Z}{\mathbb{E}} \\
\text { E } \\
\text { 心 }\end{array}$ & 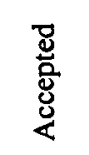 & 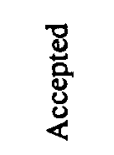 & 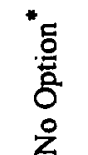 & 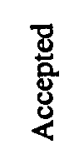 \\
\hline 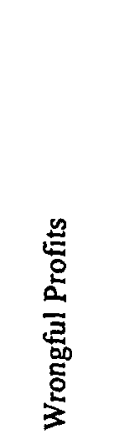 & 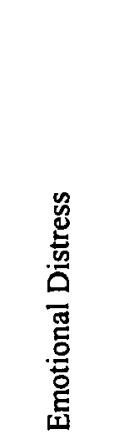 & 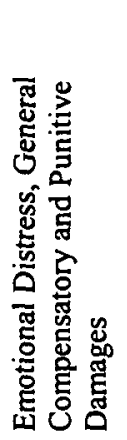 & 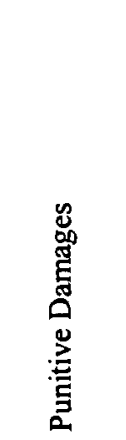 & 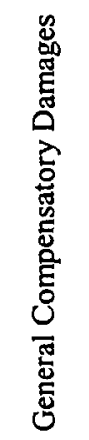 & 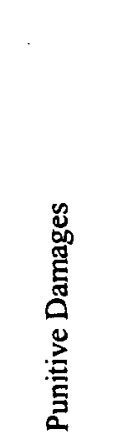 & 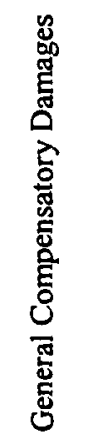 & 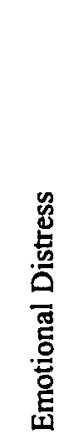 \\
\hline 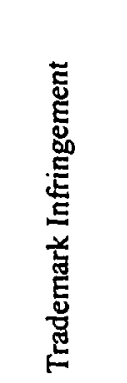 & $\frac{\infty}{\infty}$ & 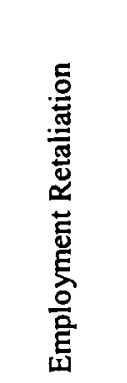 & 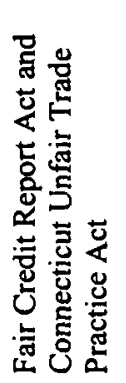 & $\frac{\mathscr{\infty}}{\stackrel{\infty}{\varrho}}$ & 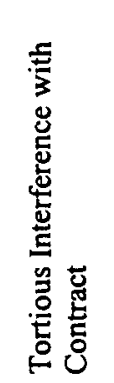 & 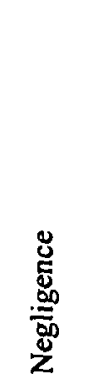 & 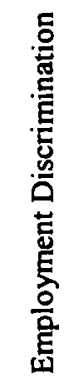 \\
\hline 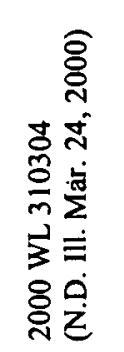 & 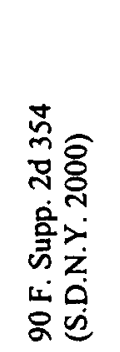 & 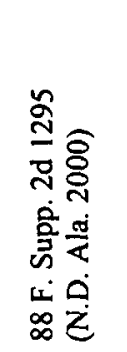 & 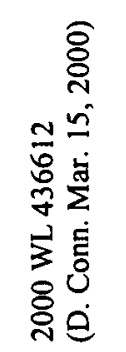 & 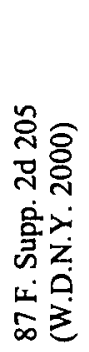 & 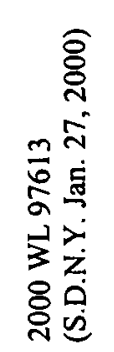 & 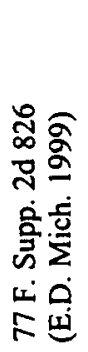 & 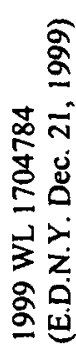 \\
\hline 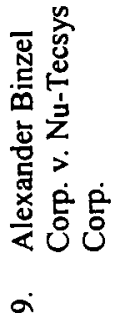 & 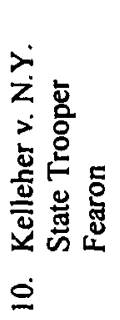 & 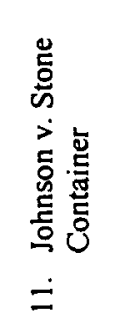 & 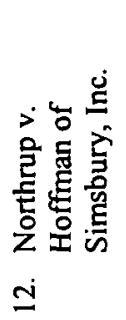 & 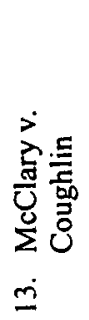 & 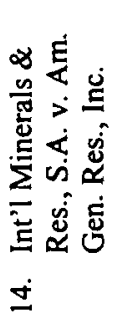 & 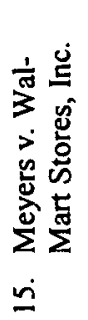 & 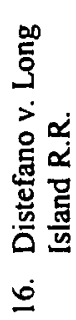 \\
\hline
\end{tabular}




\begin{tabular}{|c|c|c|c|c|c|c|c|c|}
\hline 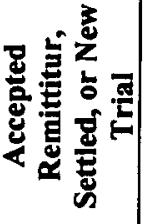 & 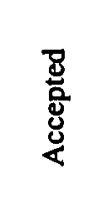 & 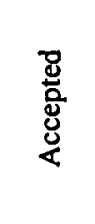 & 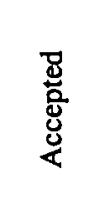 & $\begin{array}{l}\text { Dू } \\
\text { E } \\
\text { E }\end{array}$ & 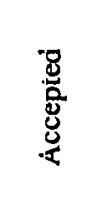 & 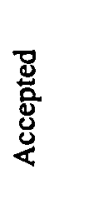 & 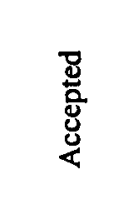 & $\begin{array}{l}\frac{Z}{\mathbb{E}} \\
\text { E }\end{array}$ \\
\hline 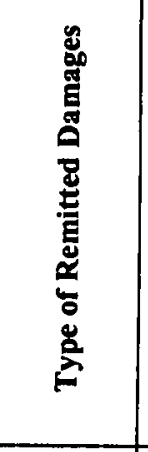 & 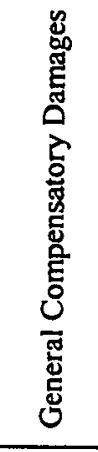 & 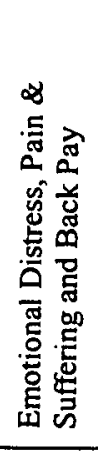 & 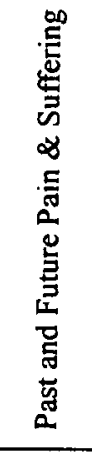 & 歌 & 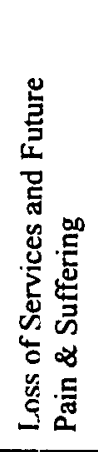 & 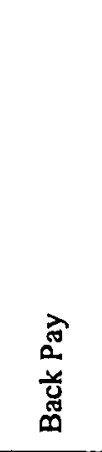 & 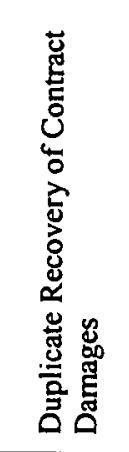 & 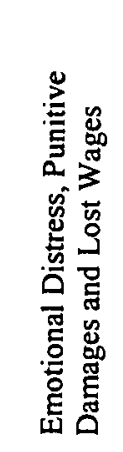 \\
\hline 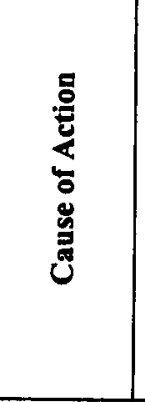 & 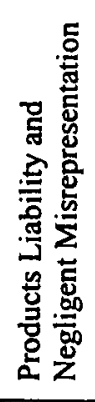 & 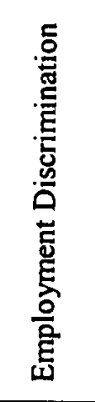 & 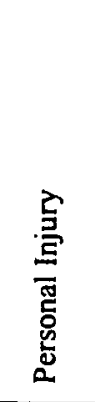 & $\frac{\infty}{\stackrel{\infty}{\Omega}}$ & 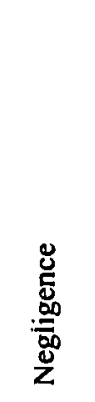 & 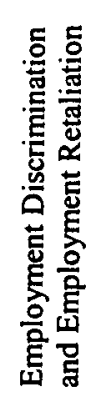 & 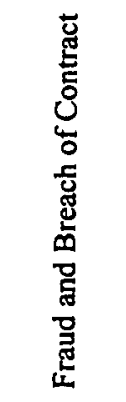 & 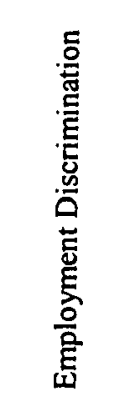 \\
\hline 总 & 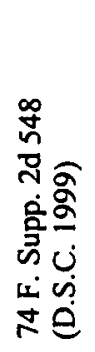 & 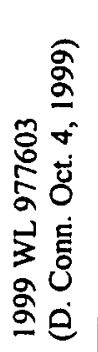 & 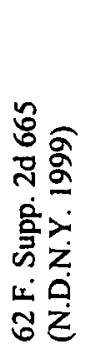 & 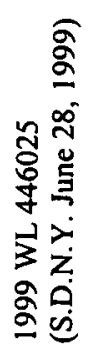 & 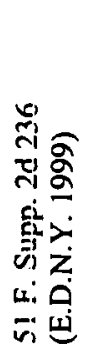 & 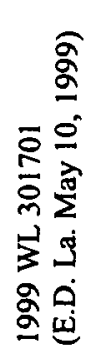 & 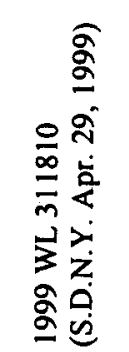 & 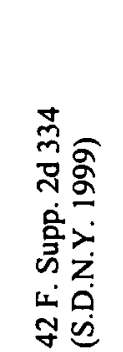 \\
\hline ֶूّ & 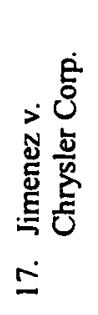 & 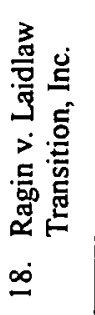 & 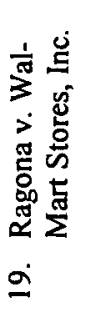 & 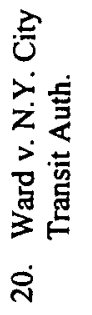 & 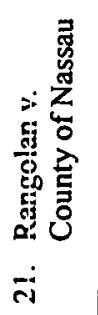 & 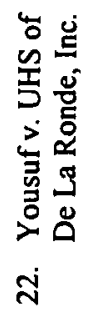 & 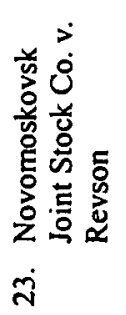 & 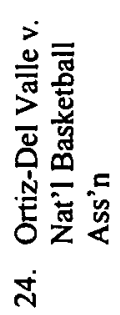 \\
\hline
\end{tabular}




\begin{tabular}{|c|c|c|c|c|c|c|c|c|}
\hline 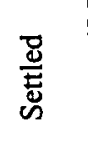 & 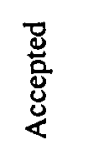 & 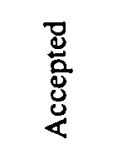 & 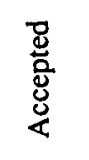 & 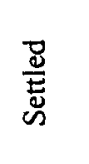 & 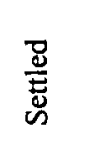 & 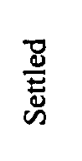 & 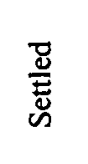 & 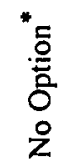 \\
\hline 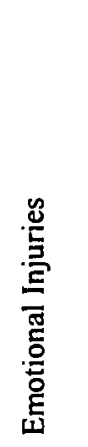 & 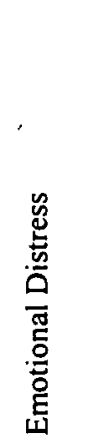 & 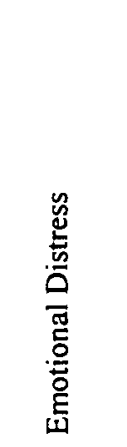 & 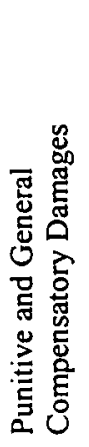 & 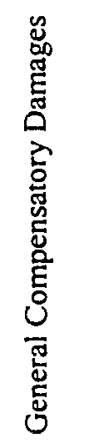 & 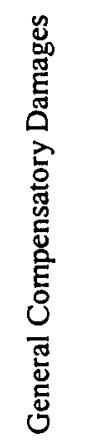 & 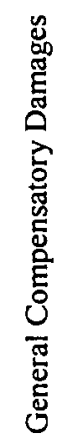 & 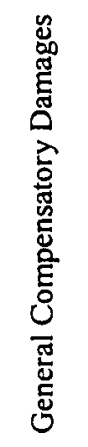 & 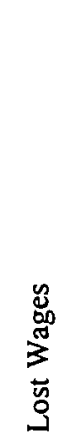 \\
\hline 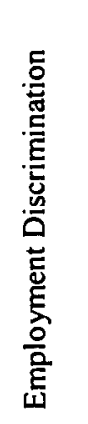 & 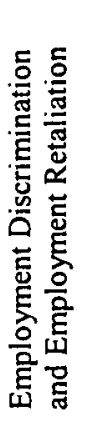 & 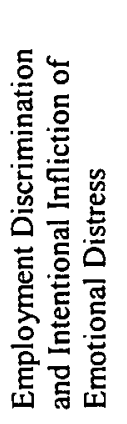 & 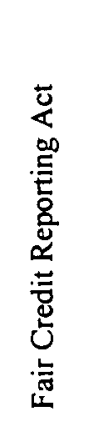 & 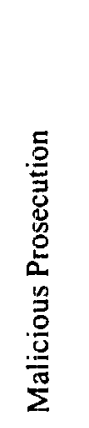 & $\frac{\stackrel{\varrho}{\varrho}}{\infty}$ & $\frac{\mathscr{O}}{\stackrel{\infty}{\infty}}$ & 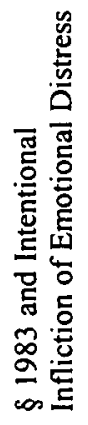 & 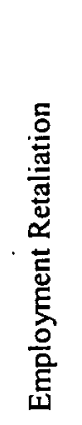 \\
\hline 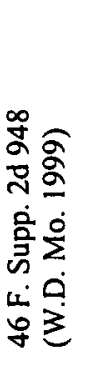 & 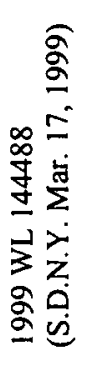 & 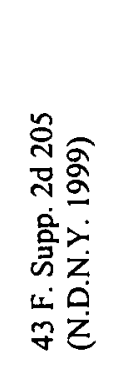 & 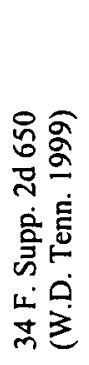 & 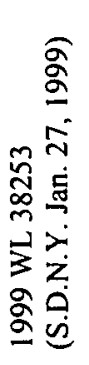 & 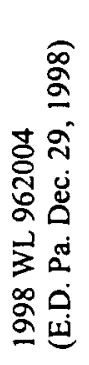 & 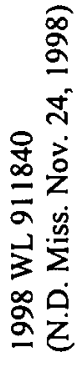 & 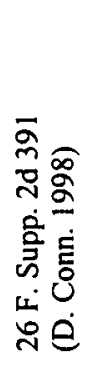 & 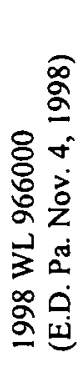 \\
\hline 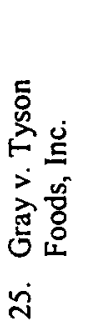 & 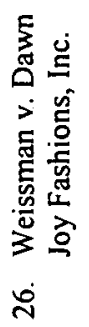 & 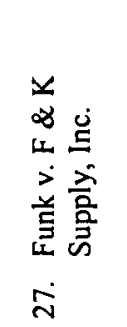 & 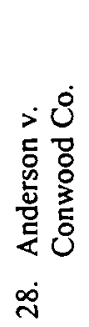 & 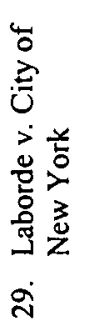 & 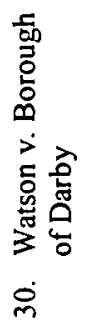 & 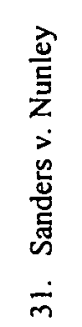 & 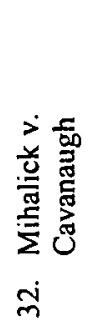 & 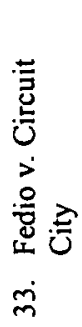 \\
\hline
\end{tabular}




\begin{tabular}{|c|c|c|c|c|c|c|c|}
\hline 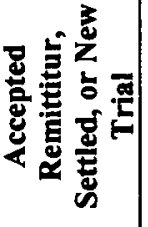 & 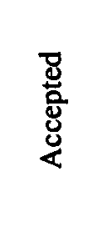 & 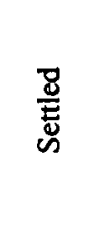 & 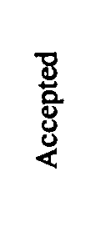 & 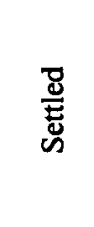 & 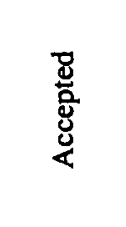 & 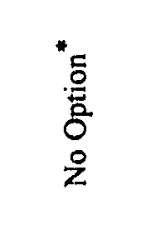 & $\begin{array}{l}{ }^{*}= \\
\dot{0} \\
\bar{o} \\
\dot{0} \\
\dot{z}\end{array}$ \\
\hline 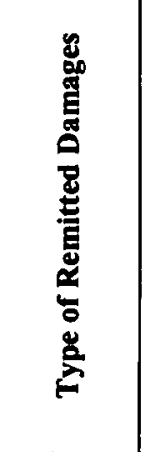 & 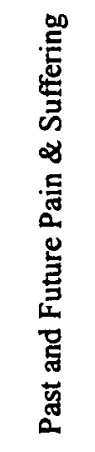 & 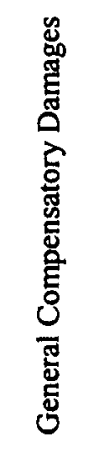 & 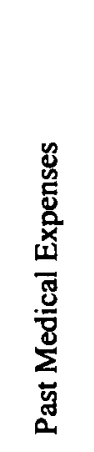 & 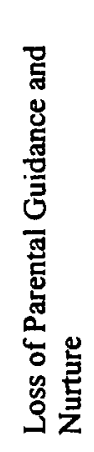 & 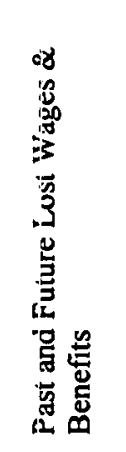 & 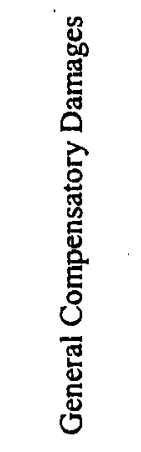 & 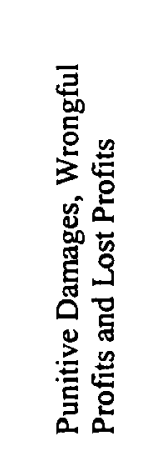 \\
\hline 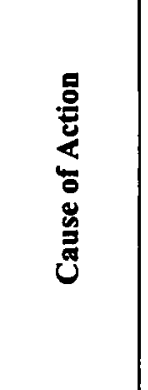 & 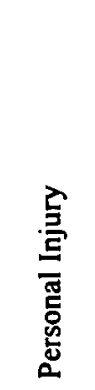 & 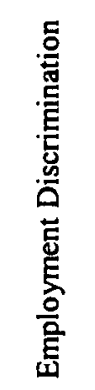 & 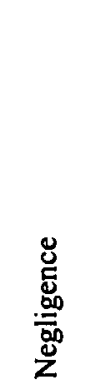 & 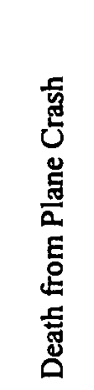 & 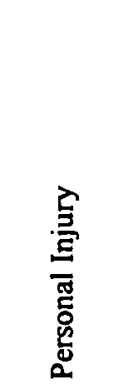 & 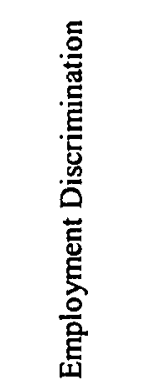 & 駌 \\
\hline 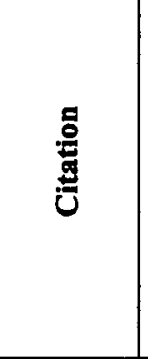 & 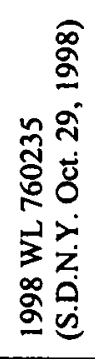 & 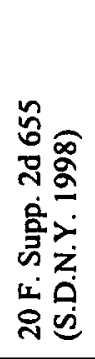 & 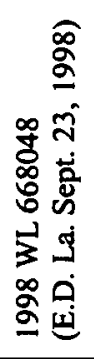 & 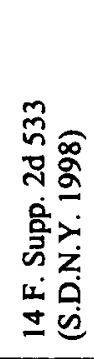 & 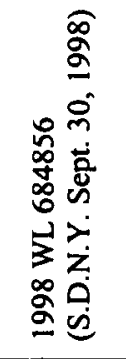 & 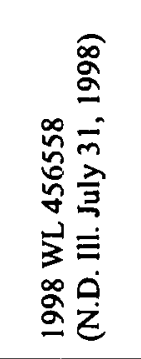 & 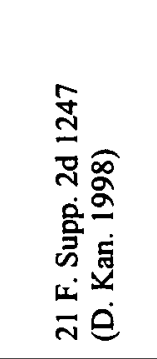 \\
\hline ฮّ & 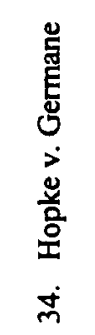 & 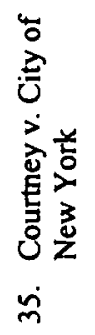 & 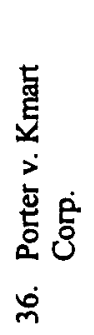 & 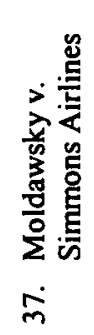 & 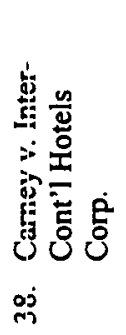 & 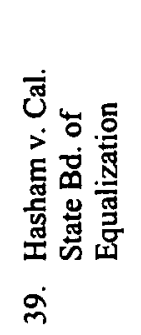 & 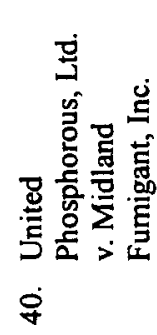 \\
\hline
\end{tabular}




\begin{tabular}{|c|c|c|c|c|c|c|c|}
\hline 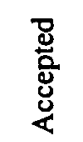 & 毣 & 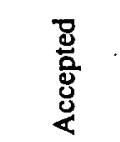 & 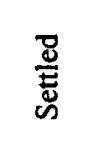 & 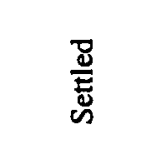 & 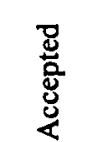 & 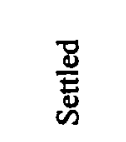 & 总 \\
\hline 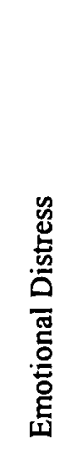 & 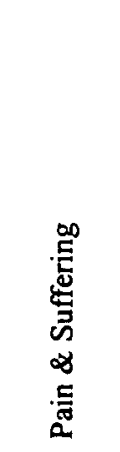 & 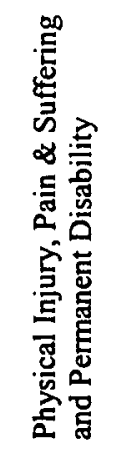 & 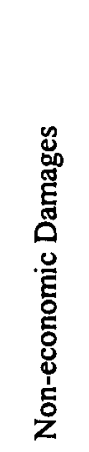 & 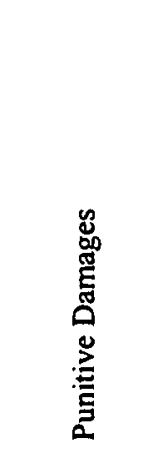 & 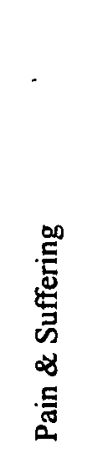 & 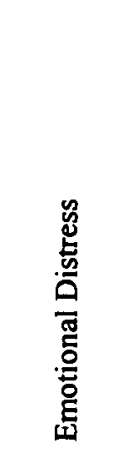 & 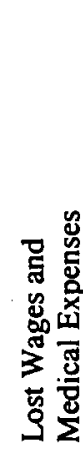 \\
\hline 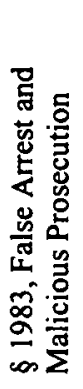 & 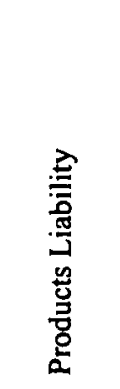 & 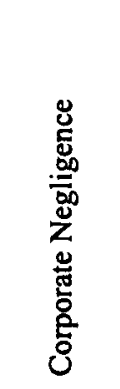 & 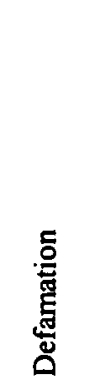 & 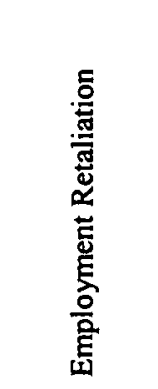 & 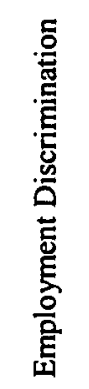 & 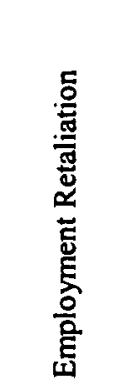 & 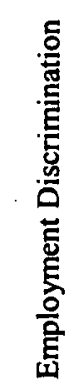 \\
\hline 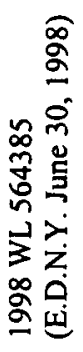 & 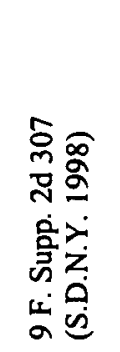 & 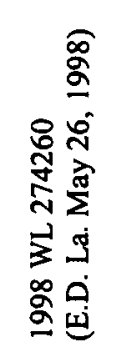 & 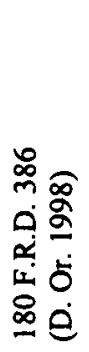 & 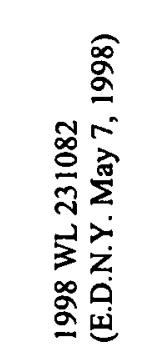 & 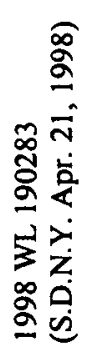 & 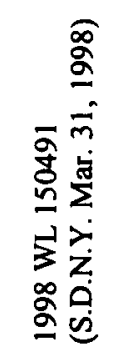 & 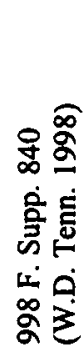 \\
\hline 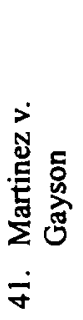 & 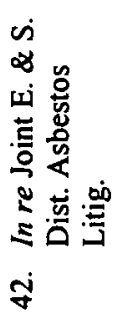 & 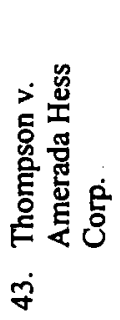 & 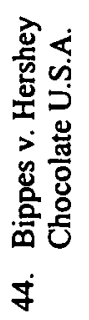 & 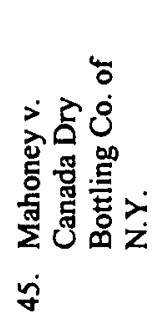 & 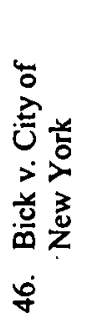 & 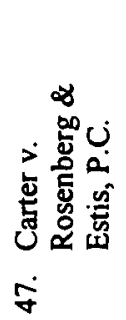 & 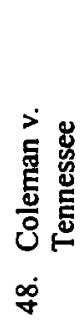 \\
\hline
\end{tabular}




\begin{tabular}{|c|c|c|c|c|c|c|c|c|c|}
\hline 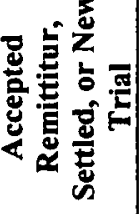 & 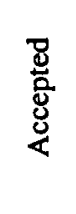 & 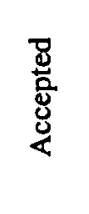 & 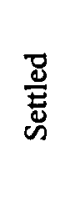 & 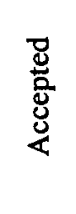 & 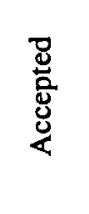 & 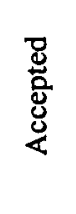 & 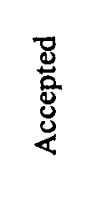 & 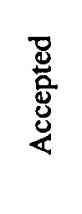 & 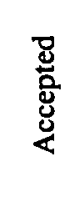 \\
\hline 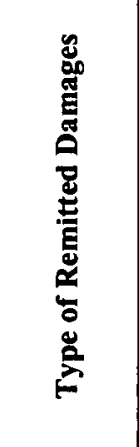 & 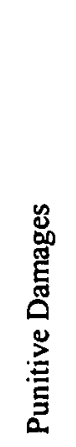 & 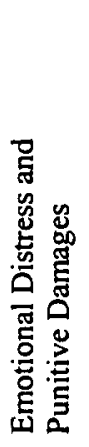 & 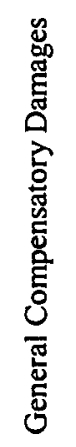 & 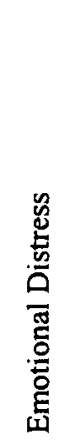 & 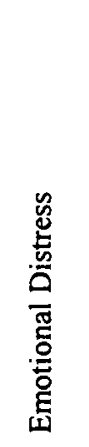 & 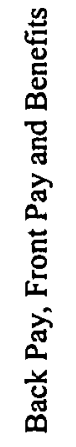 & 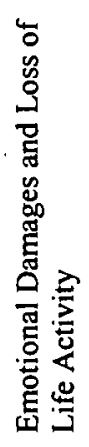 & 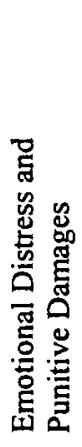 & 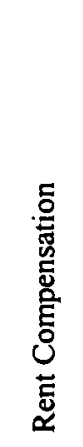 \\
\hline 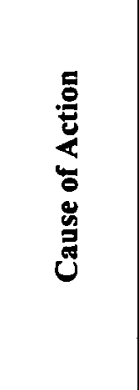 & 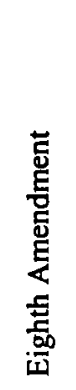 & 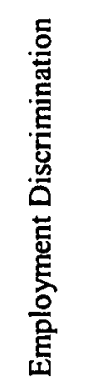 & 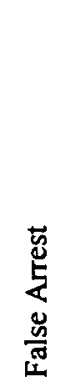 & 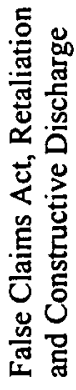 & 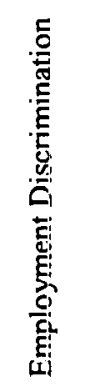 & 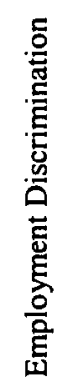 & $\begin{array}{l}\text { 롤 } \\
\bar{\Xi} \\
\overline{0} \\
\overline{0} \\
\frac{0}{2} \\
2\end{array}$ & 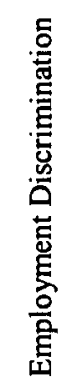 & 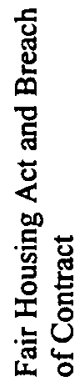 \\
\hline & 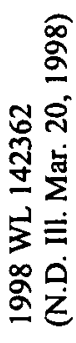 & 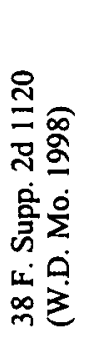 & 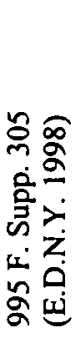 & 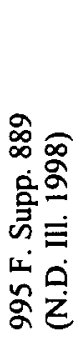 & 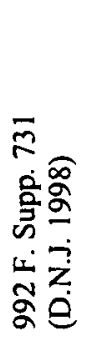 & 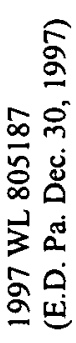 & 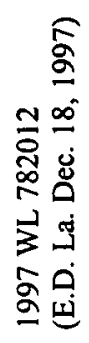 & 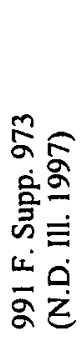 & 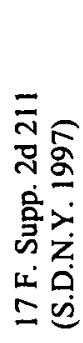 \\
\hline 亗 & 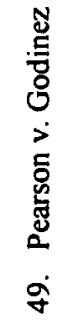 & 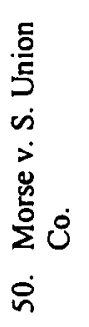 & 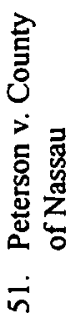 & 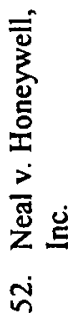 & 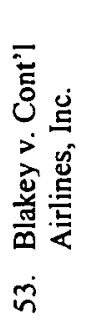 & 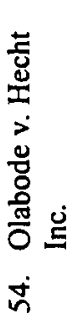 & 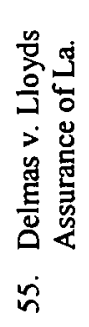 & 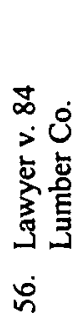 & 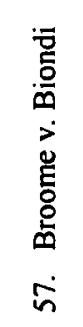 \\
\hline
\end{tabular}




\begin{tabular}{|c|c|c|c|c|c|c|c|}
\hline 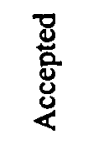 & 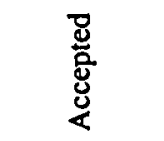 & 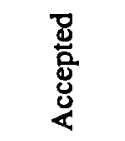 & 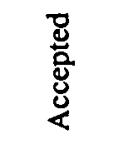 & 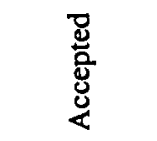 & 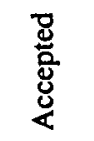 & $\begin{array}{l}\frac{\bar{d}}{E} \\
\stackrel{\bar{D}}{n}\end{array}$ & 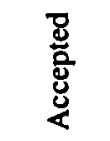 \\
\hline 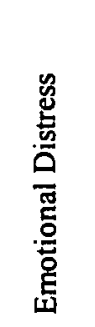 & 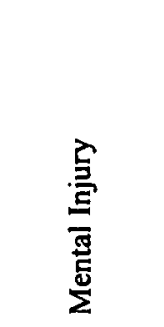 & 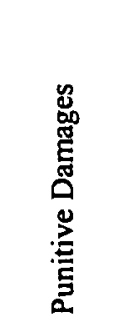 & 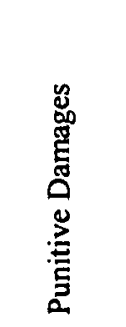 & 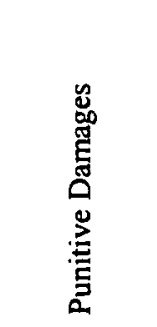 & 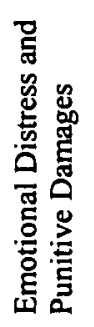 & 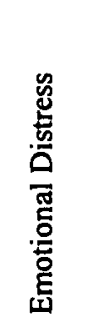 & 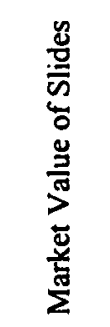 \\
\hline 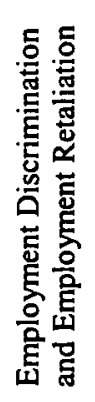 & 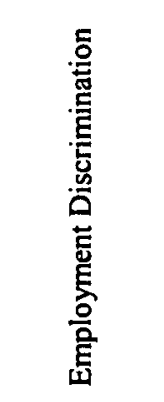 & 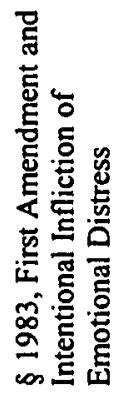 & 总 & 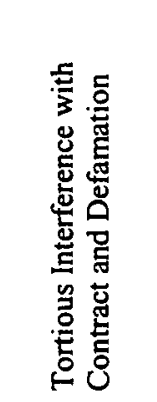 & 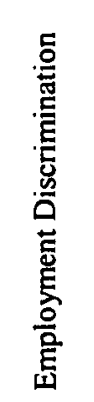 & 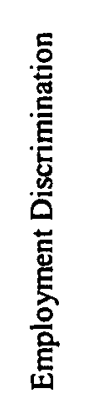 & 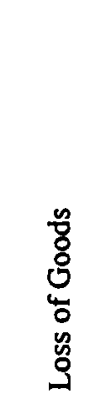 \\
\hline 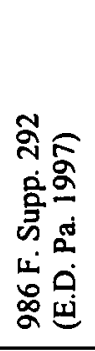 & 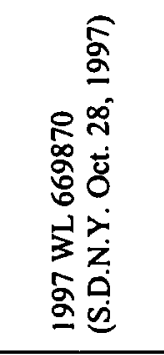 & 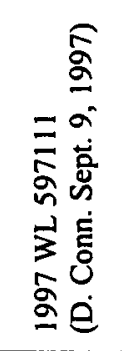 & 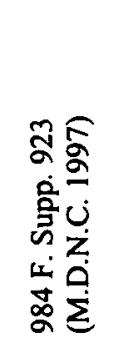 & 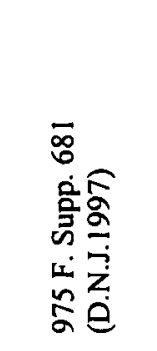 & 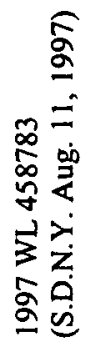 & 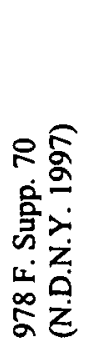 & 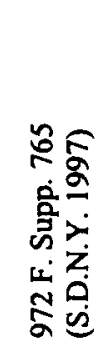 \\
\hline 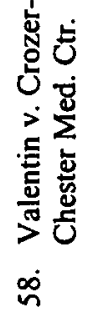 & 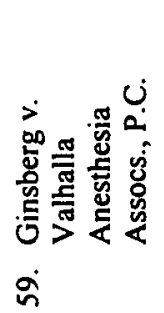 & 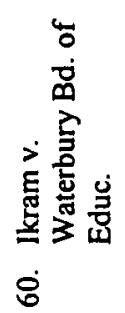 & 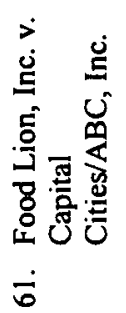 & 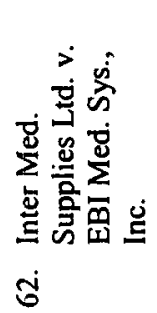 & 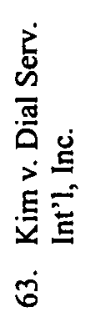 & 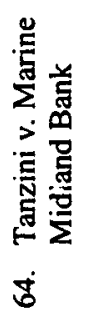 & 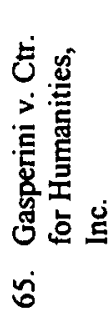 \\
\hline
\end{tabular}




\begin{tabular}{|c|c|c|c|c|c|c|c|c|}
\hline 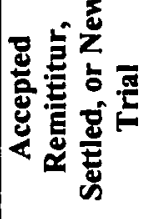 & 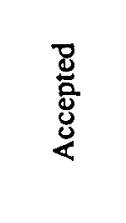 & 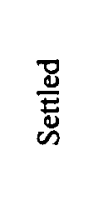 & 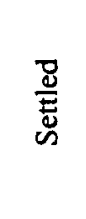 & 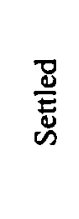 & $\begin{array}{l}\frac{\bar{U}}{E} \\
\stackrel{\bar{U}}{n}\end{array}$ & $\begin{array}{l}\frac{\bar{U}}{\bar{E}} \\
\stackrel{\bar{N}}{ }\end{array}$ & 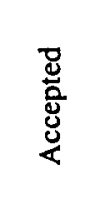 & 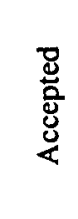 \\
\hline 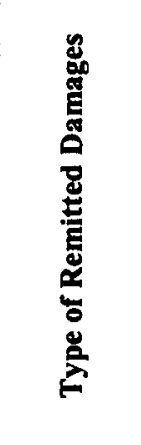 & 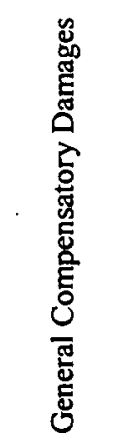 & 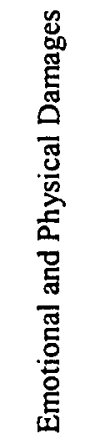 & 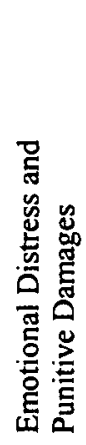 & 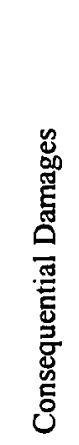 & 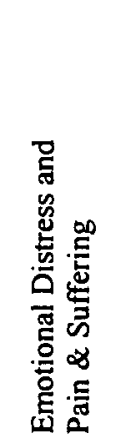 & 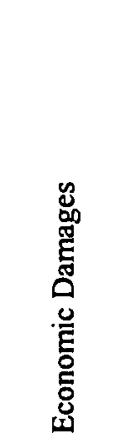 & 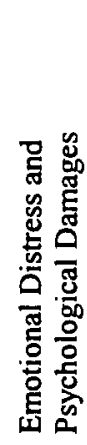 & 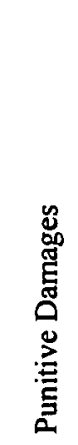 \\
\hline 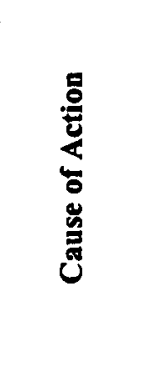 & 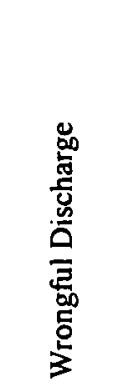 & 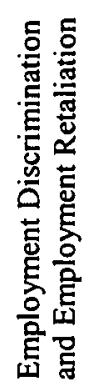 & 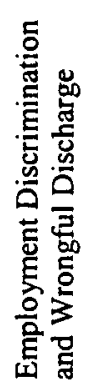 & 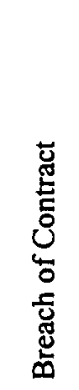 & 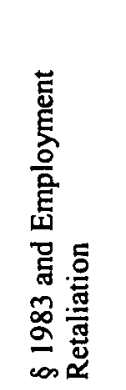 & 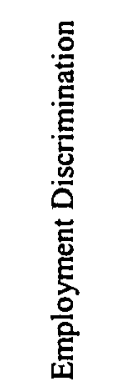 & 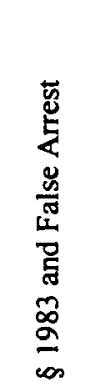 & 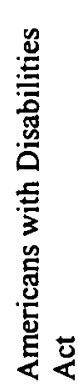 \\
\hline 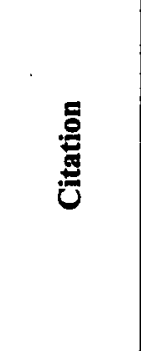 & 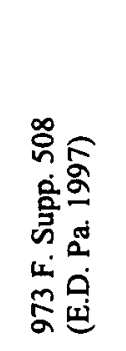 & 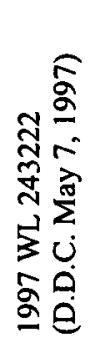 & 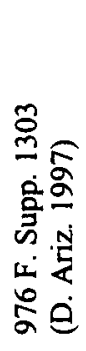 & 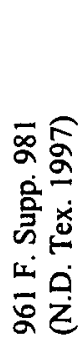 & 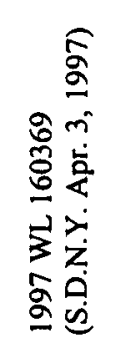 & 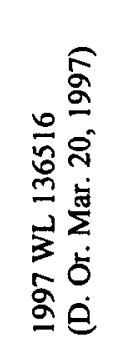 & 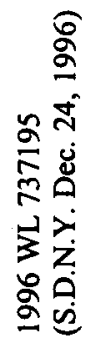 & 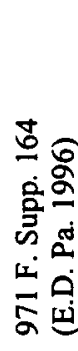 \\
\hline Uू. & 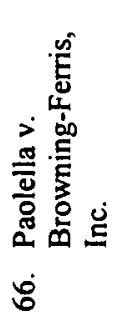 & 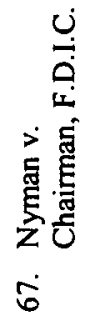 & 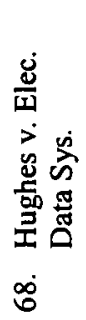 & 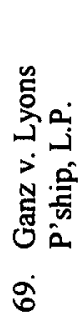 & 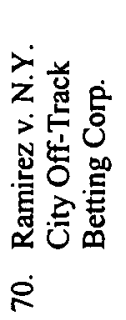 & 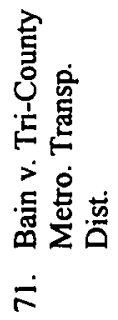 & 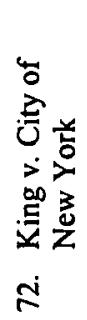 & 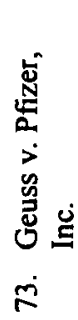 \\
\hline
\end{tabular}




\begin{tabular}{|c|c|c|c|c|c|c|c|}
\hline $\begin{array}{l}\text { "s } \\
.0 \\
0 \\
0 \\
0 \\
z\end{array}$ & 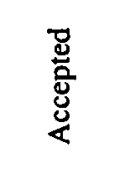 & 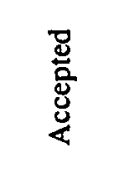 & 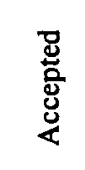 & $\begin{array}{l}\text { 믈 } \\
\text { ó } \\
\text { z }\end{array}$ & $\begin{array}{l}\text { ठ্̈ } \\
\bar{E} \\
\text { ڤ̆ }\end{array}$ & 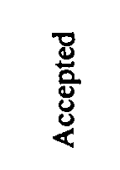 & 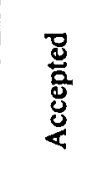 \\
\hline 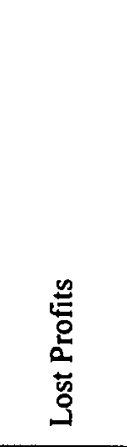 & 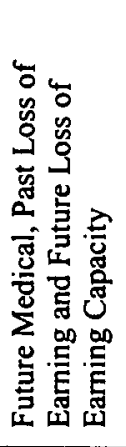 & 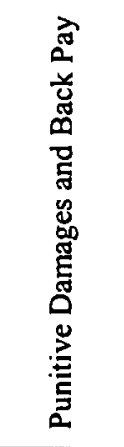 & 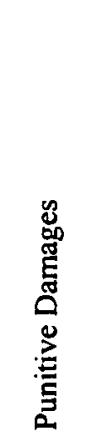 & 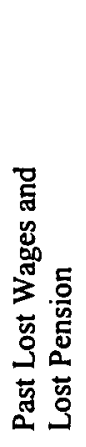 & 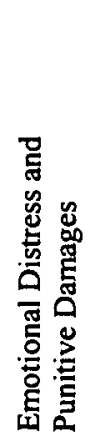 & 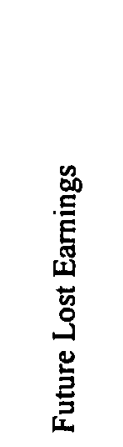 & 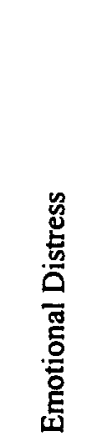 \\
\hline 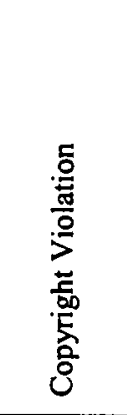 & 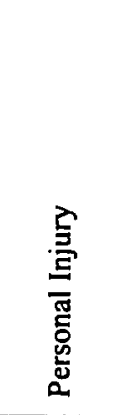 & 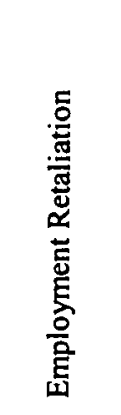 & 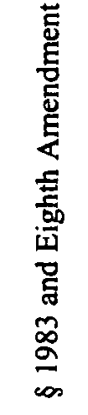 & $\frac{\infty}{\cos }$ & $\frac{\tilde{\alpha}}{\cos }$ & 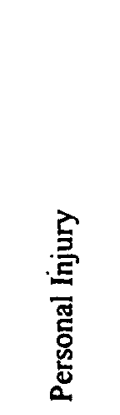 & 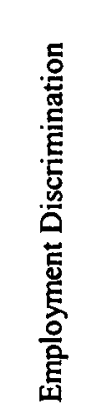 \\
\hline 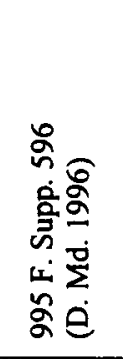 & 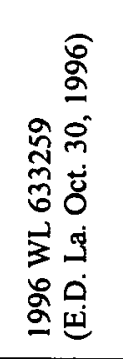 & 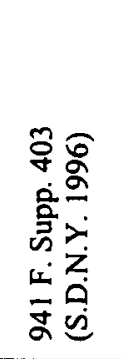 & 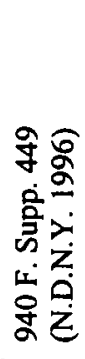 & 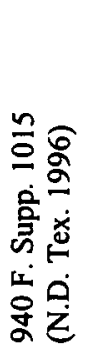 & 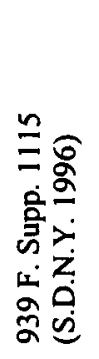 & 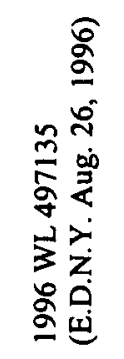 & 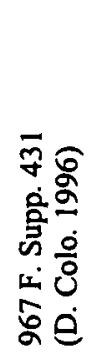 \\
\hline 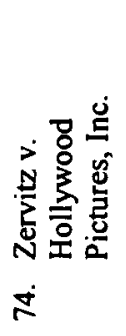 & 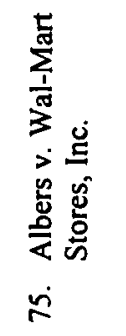 & 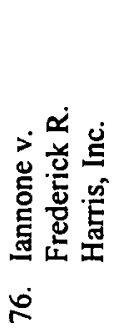 & 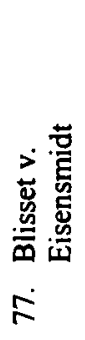 & 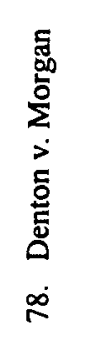 & 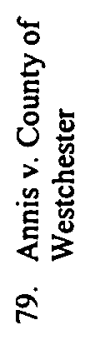 & 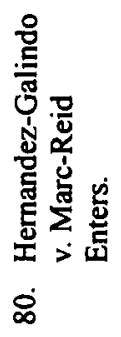 & 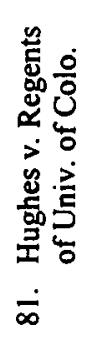 \\
\hline
\end{tabular}




\begin{tabular}{|c|c|c|c|c|c|c|c|c|}
\hline 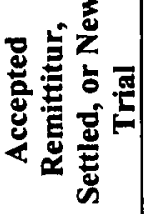 & 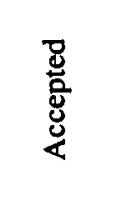 & 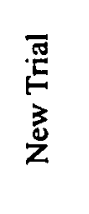 & 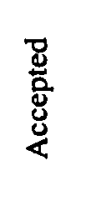 & 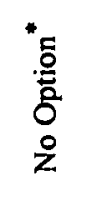 & 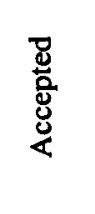 & 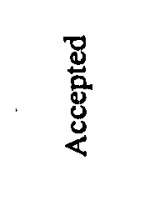 & 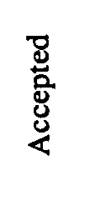 & 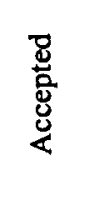 \\
\hline 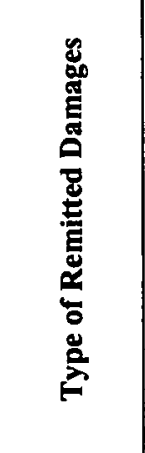 & 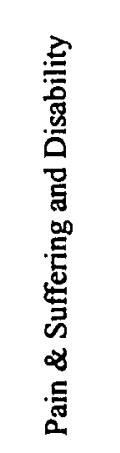 & 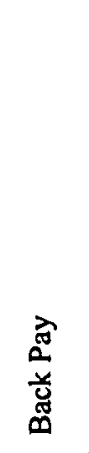 & 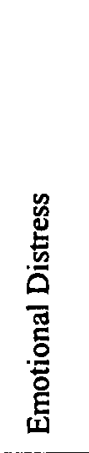 & 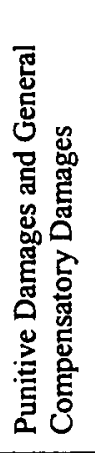 & 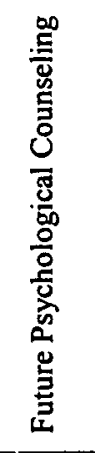 & 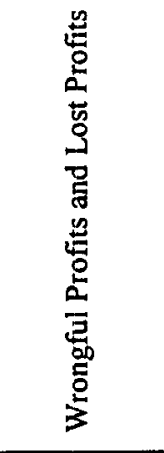 & 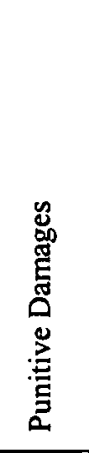 & 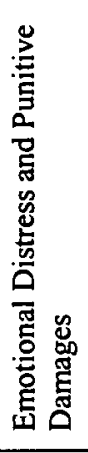 \\
\hline 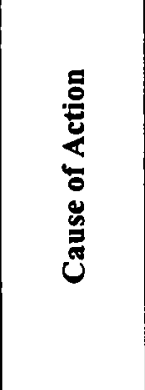 & 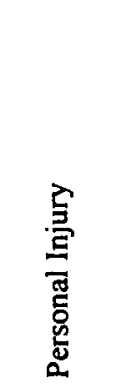 & 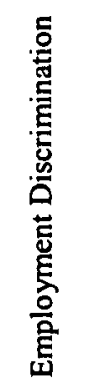 & 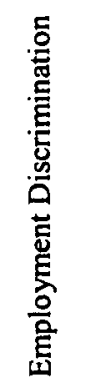 & 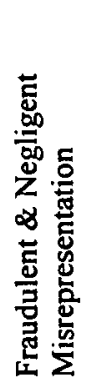 & 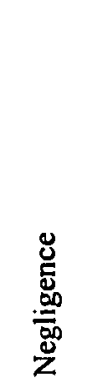 & 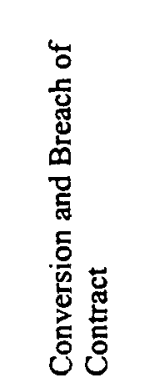 & $\frac{\hat{\mathscr{O}}}{\cos }$ & 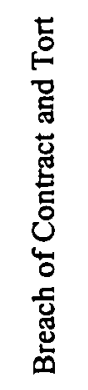 \\
\hline & 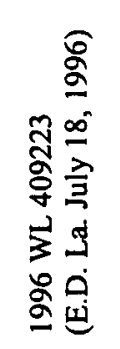 & 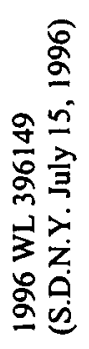 & 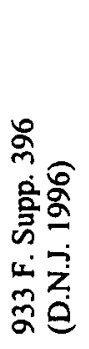 & 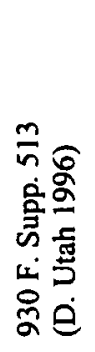 & 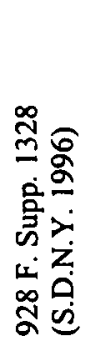 & 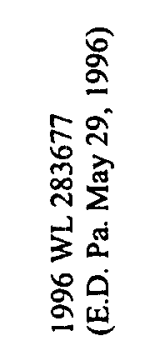 & 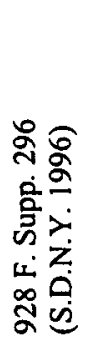 & 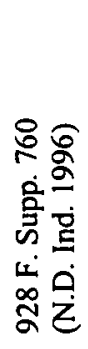 \\
\hline ర్ & 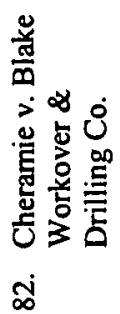 & 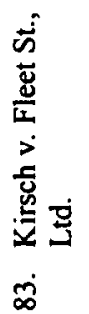 & 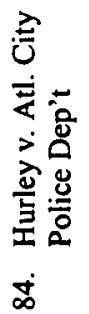 & 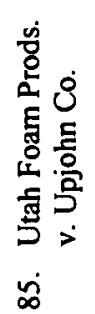 & 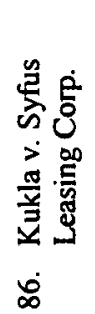 & 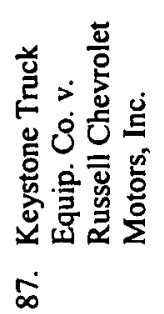 & 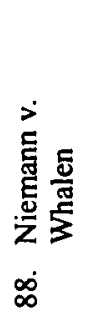 & 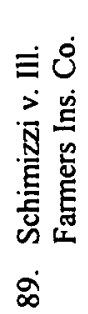 \\
\hline
\end{tabular}




\begin{tabular}{|c|c|c|c|c|c|c|c|c|}
\hline 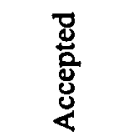 & 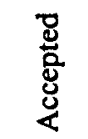 & 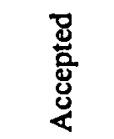 & 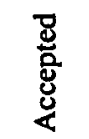 & 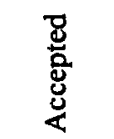 & 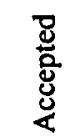 & 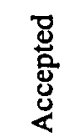 & 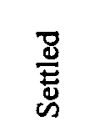 & 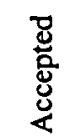 \\
\hline 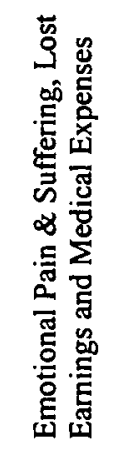 & 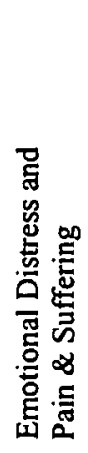 & 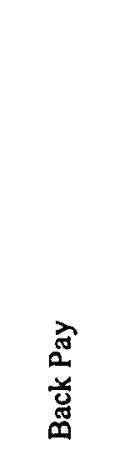 & 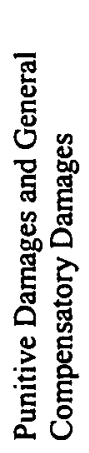 & 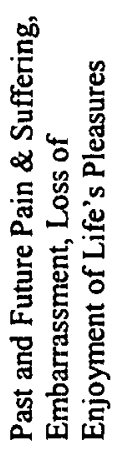 & 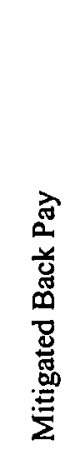 & 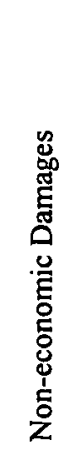 & 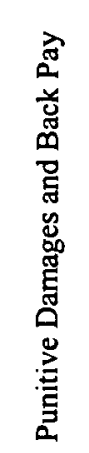 & 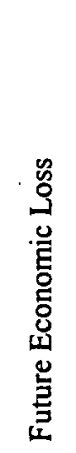 \\
\hline 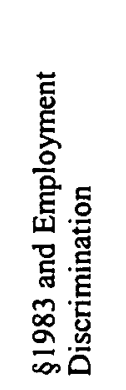 & 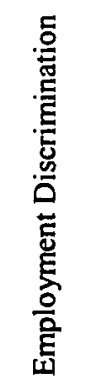 & 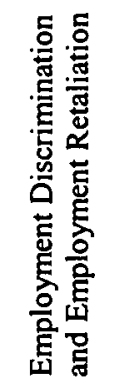 & 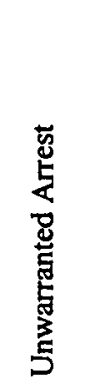 & 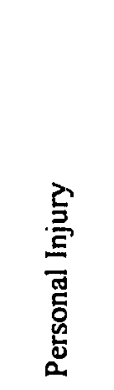 & 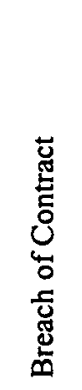 & 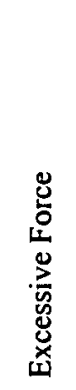 & 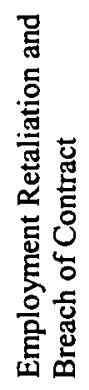 & 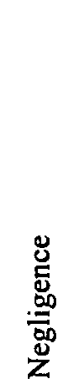 \\
\hline 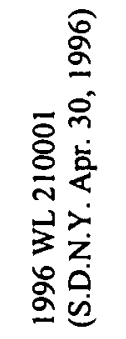 & 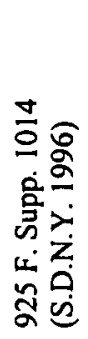 & 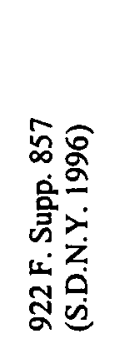 & 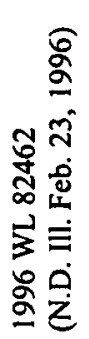 & 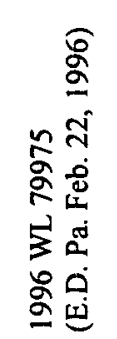 & 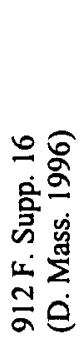 & 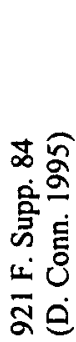 & 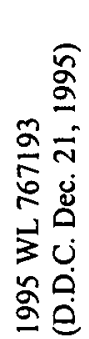 & 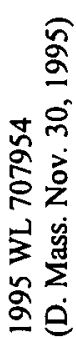 \\
\hline 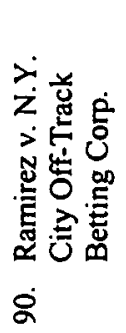 & 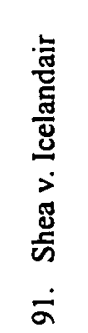 & 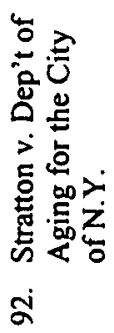 & 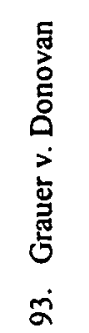 & 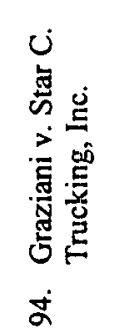 & 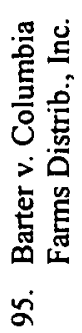 & 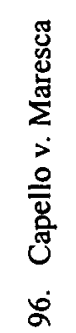 & 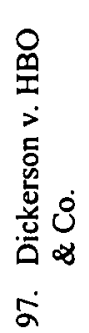 & 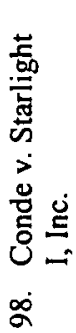 \\
\hline
\end{tabular}




\begin{tabular}{|c|c|c|c|c|c|c|c|}
\hline 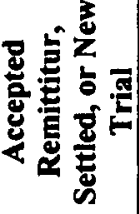 & 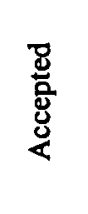 & 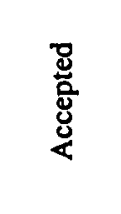 & $\begin{array}{l}\bar{z} \\
\text { 总 } \\
z \\
z\end{array}$ & 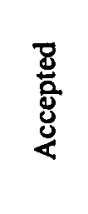 & 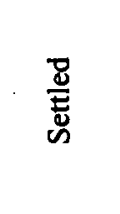 & 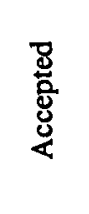 & 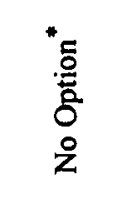 \\
\hline 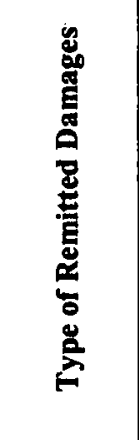 & 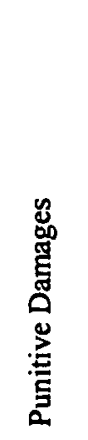 & 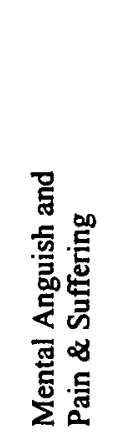 & 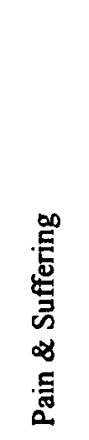 & 总 & 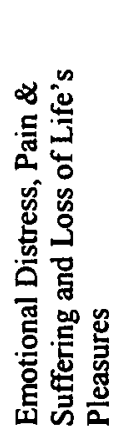 & 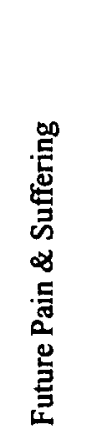 & 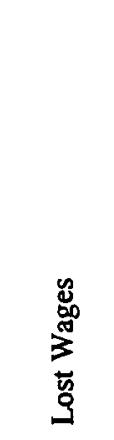 \\
\hline 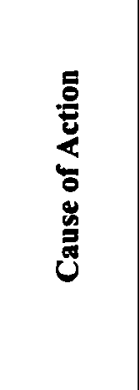 & 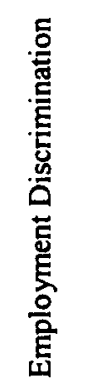 & 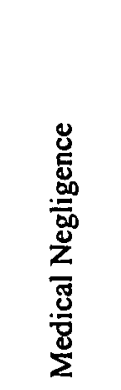 & 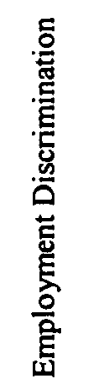 & 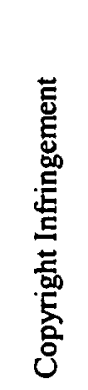 & 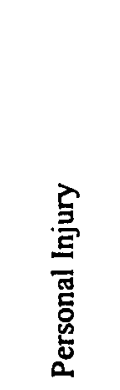 & 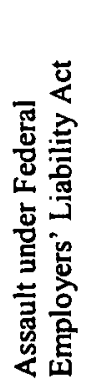 & 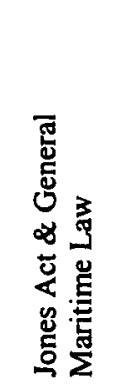 \\
\hline 氖 & 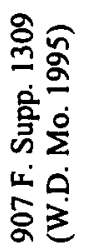 & 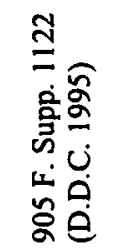 & 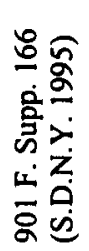 & 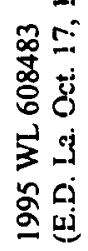 & 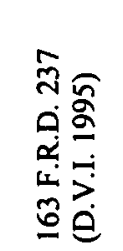 & 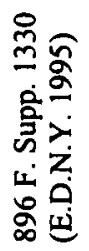 & 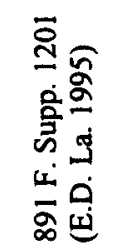 \\
\hline 司 & 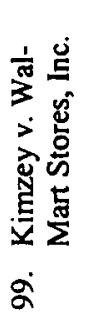 & 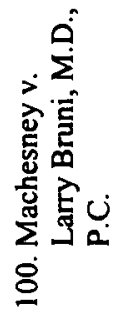 & 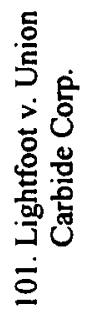 & 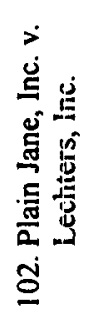 & 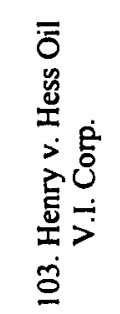 & 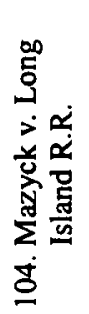 & 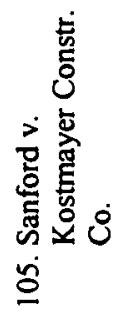 \\
\hline
\end{tabular}




\begin{tabular}{|c|c|c|c|c|c|c|c|}
\hline 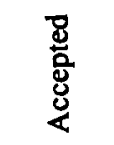 & 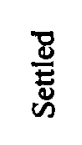 & 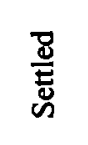 & 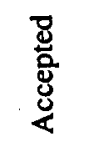 & 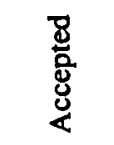 & 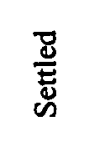 & 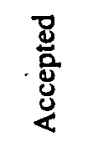 & 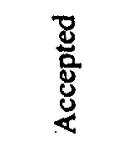 \\
\hline 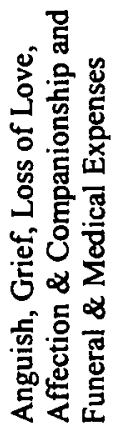 & 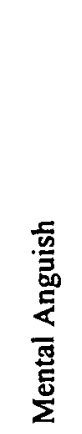 & 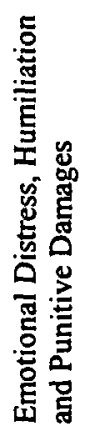 & 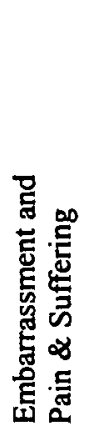 & 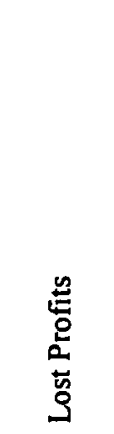 & 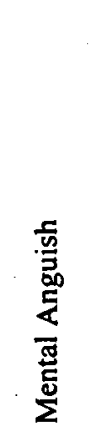 & 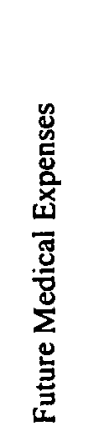 & 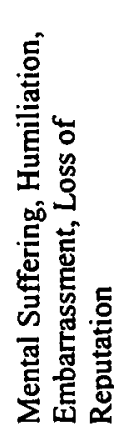 \\
\hline 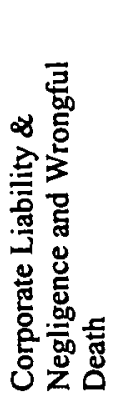 & 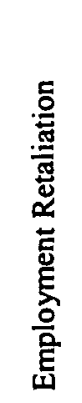 & 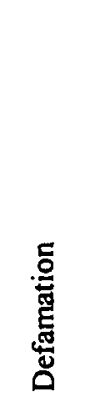 & 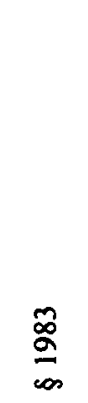 & 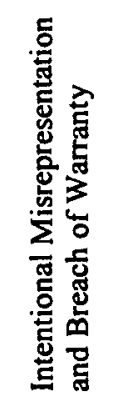 & 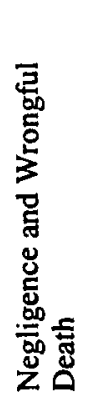 & 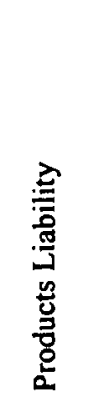 & 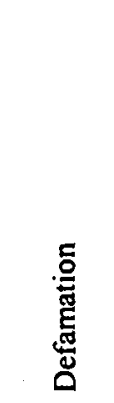 \\
\hline 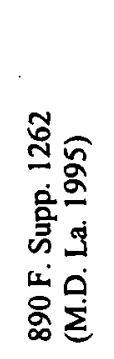 & 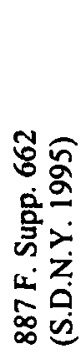 & 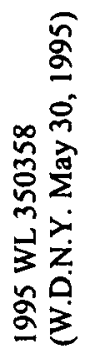 & 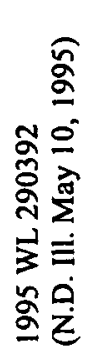 & 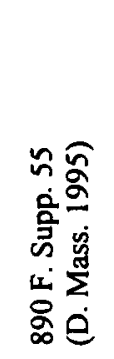 & 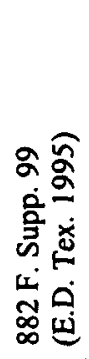 & 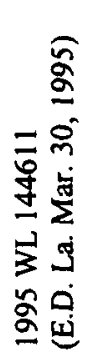 & 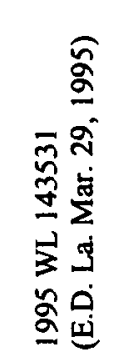 \\
\hline 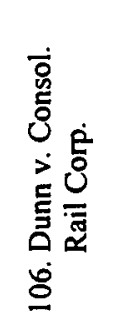 & 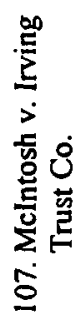 & 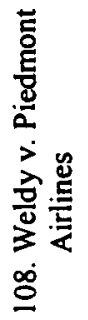 & 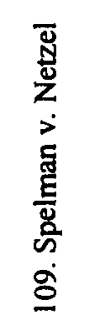 & 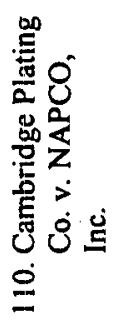 & 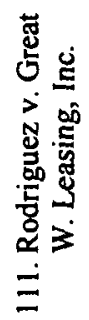 & 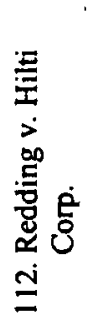 & 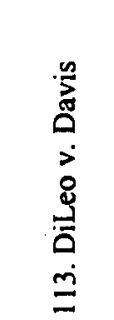 \\
\hline
\end{tabular}




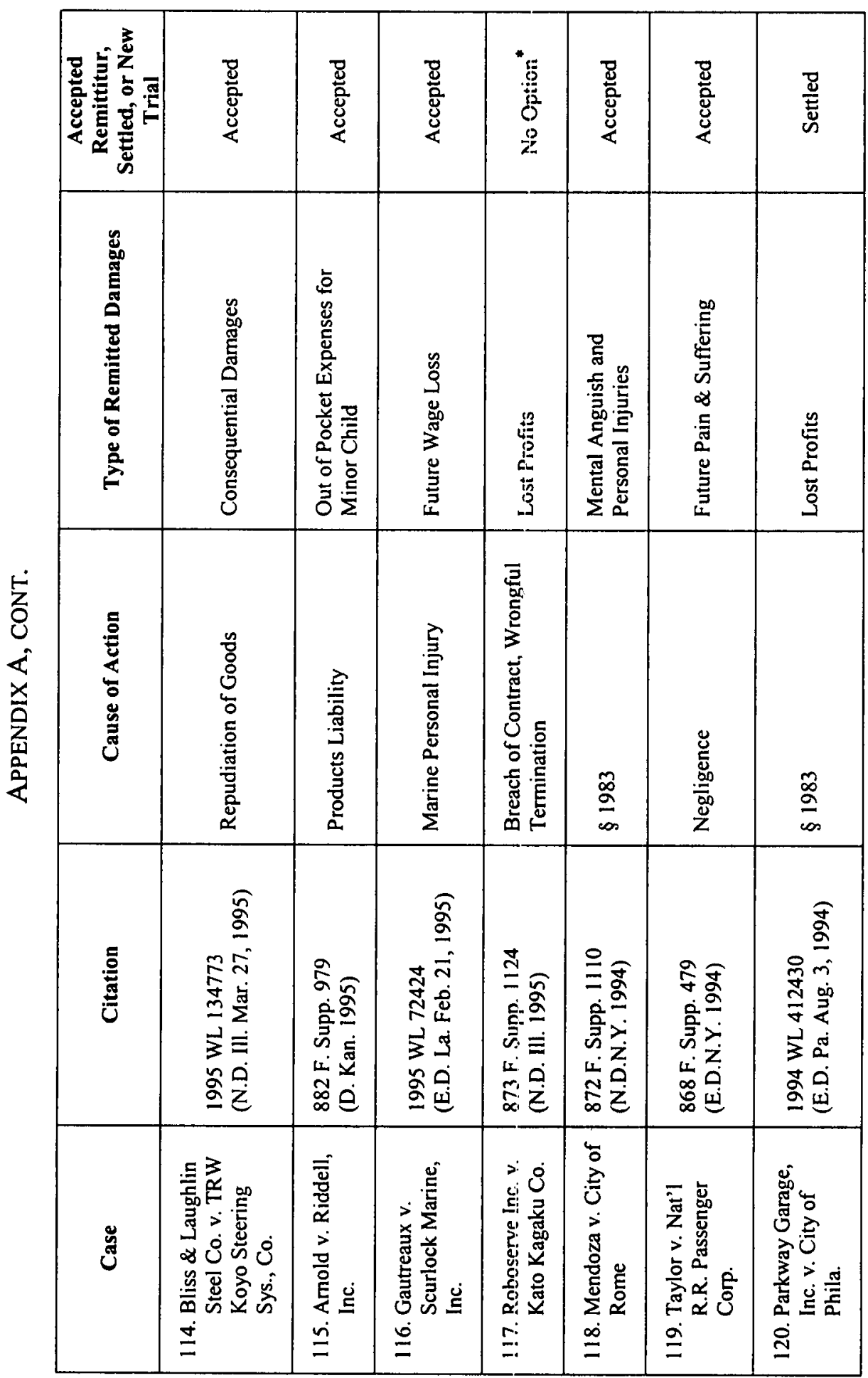




\begin{tabular}{|c|c|c|c|c|c|c|c|c|}
\hline $\begin{array}{l}{ }^{*} \bar{o} \\
\stackrel{0}{0} \\
0 \\
\circ \\
\circ \\
z\end{array}$ & 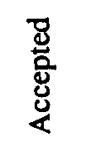 & 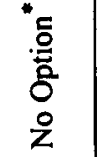 & 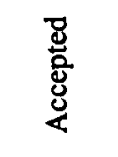 & 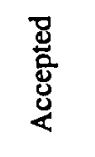 & $\begin{array}{l}\vec{Z} \\
\bar{E} \\
\text { E }\end{array}$ & 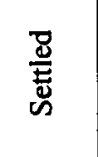 & 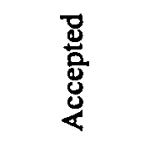 & 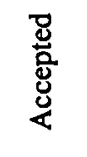 \\
\hline 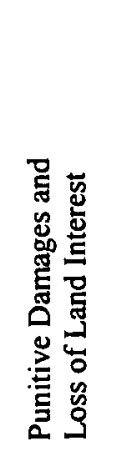 & 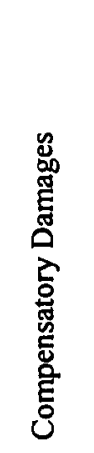 & 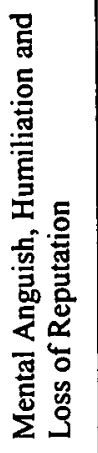 & 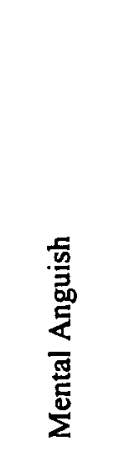 & 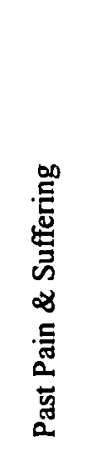 & 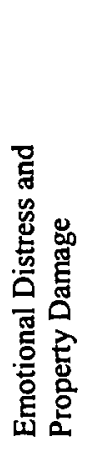 & 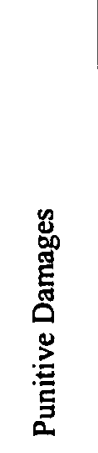 & 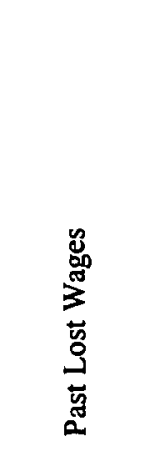 & 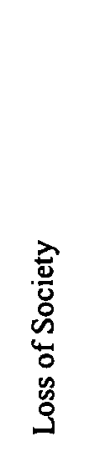 \\
\hline 䙔 & 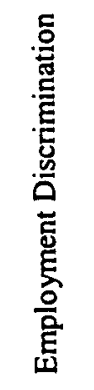 & 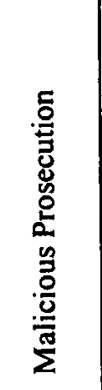 & 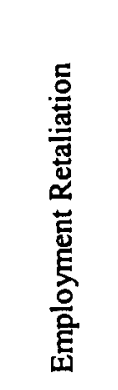 & 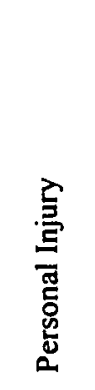 & 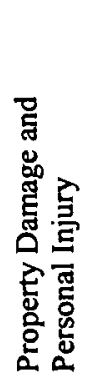 & 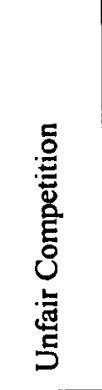 & $\begin{array}{l}\bar{y} \\
\bar{d} \\
\overline{0} \\
\vdots\end{array}$ & $\frac{\infty}{\stackrel{0}{\varrho}}$ \\
\hline 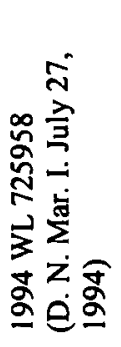 & 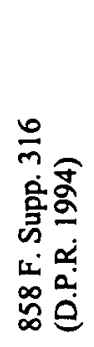 & 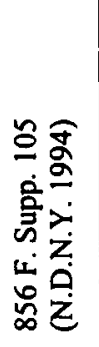 & 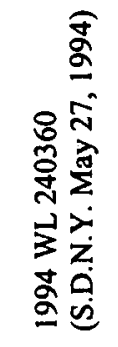 & 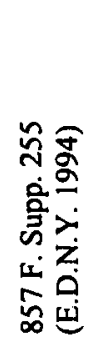 & 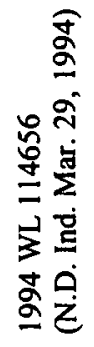 & 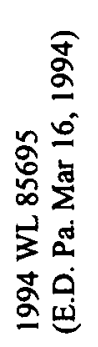 & 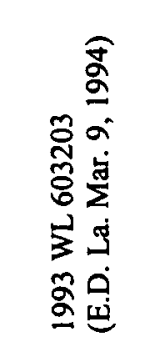 & 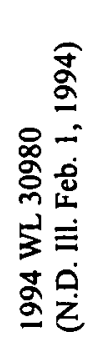 \\
\hline 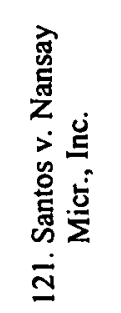 & 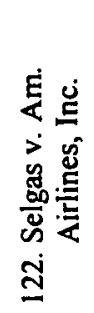 & 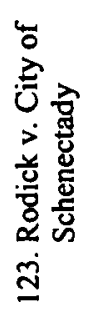 & 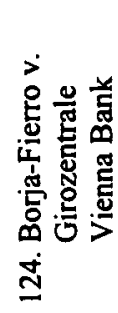 & 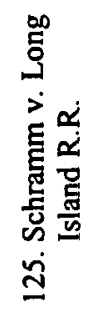 & 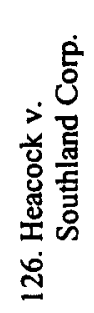 & 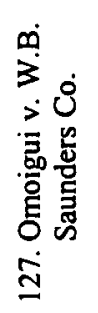 & 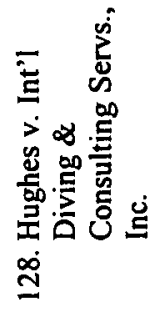 & 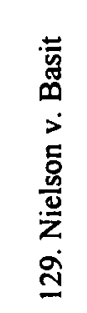 \\
\hline
\end{tabular}




\begin{tabular}{|c|c|c|c|c|c|c|c|c|}
\hline 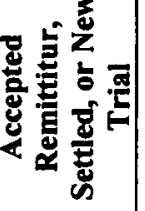 & $\begin{array}{l}\frac{Z}{E} \\
\frac{E}{E} \\
\qquad\end{array}$ & 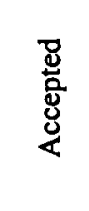 & $\begin{array}{l}\text { 导 } \\
\text { 总 }\end{array}$ & 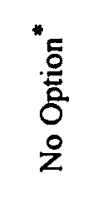 & $\begin{array}{l}\text { 菍 } \\
\text { 岕 }\end{array}$ & 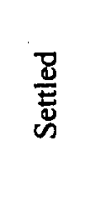 & 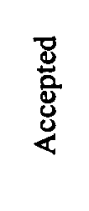 & 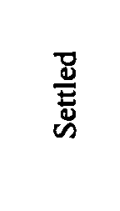 \\
\hline 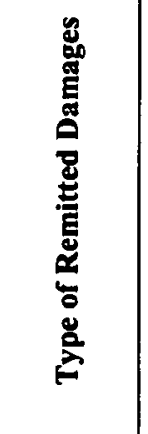 & 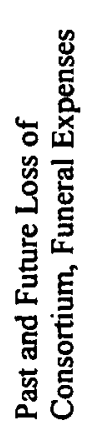 & 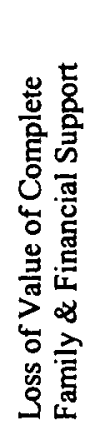 & 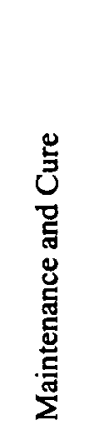 & 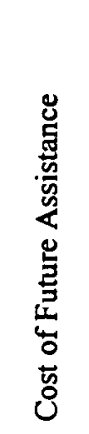 & 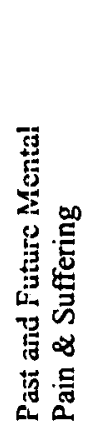 & 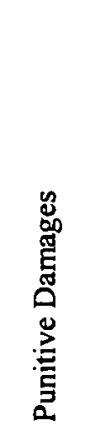 & 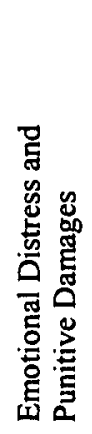 & 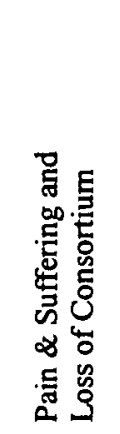 \\
\hline 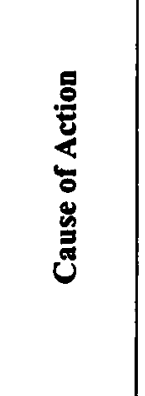 & 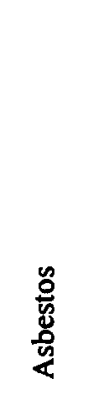 & 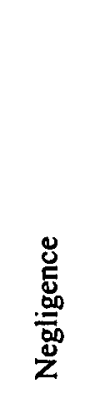 & 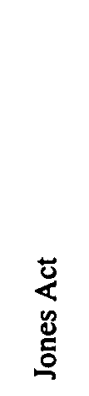 & 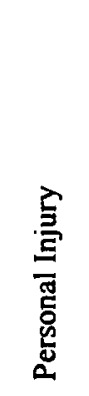 & 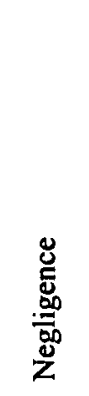 & 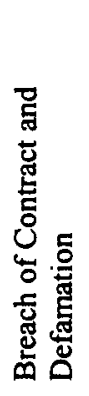 & 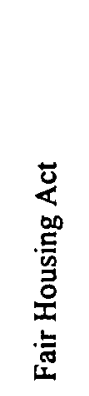 & 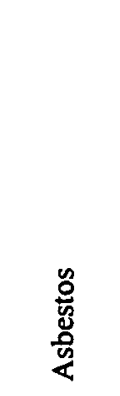 \\
\hline & 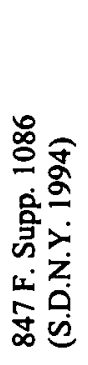 & 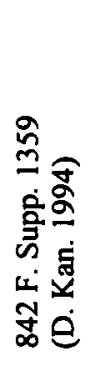 & 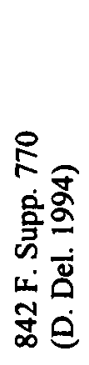 & 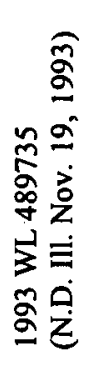 & 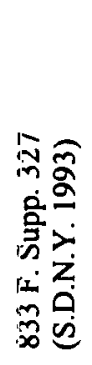 & 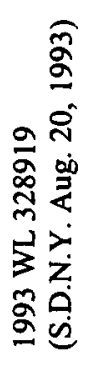 & 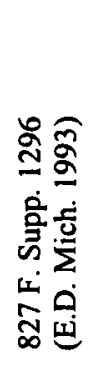 & 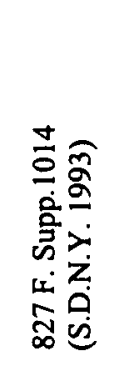 \\
\hline $\mathscr{J}^{\mathscr{g}}$ & 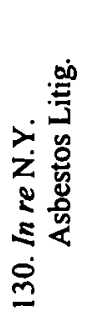 & 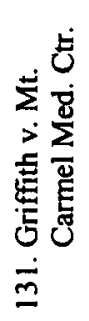 & 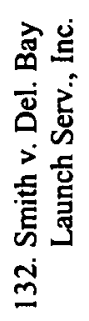 & 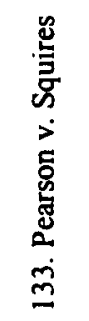 & 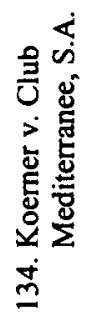 & 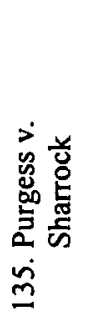 & 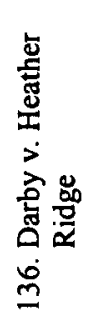 & 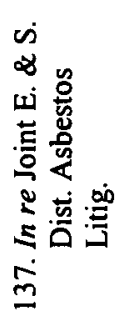 \\
\hline
\end{tabular}




\begin{tabular}{|c|c|c|c|c|c|c|c|c|}
\hline $\begin{array}{l}\frac{\bar{U}}{E} \\
\frac{\vec{E}}{\mathscr{W}}\end{array}$ & 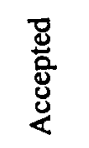 & 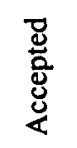 & 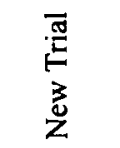 & 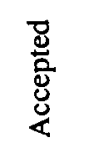 & 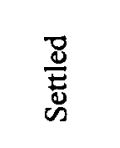 & 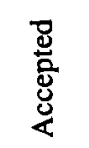 & 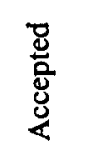 & 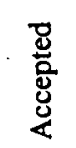 \\
\hline 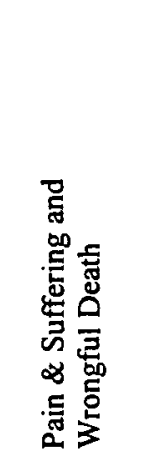 & 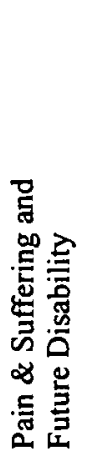 & 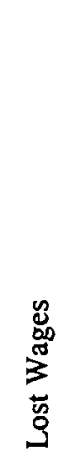 & 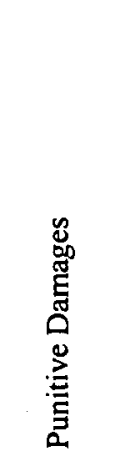 & 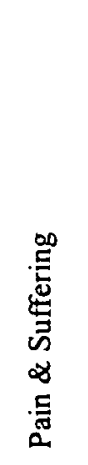 & 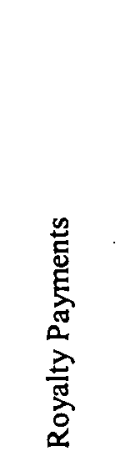 & 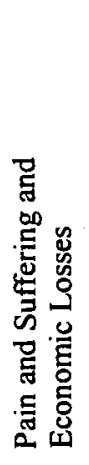 & 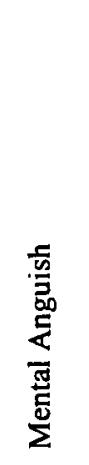 & 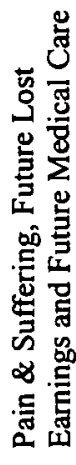 \\
\hline 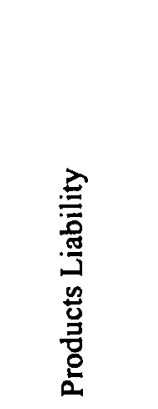 & 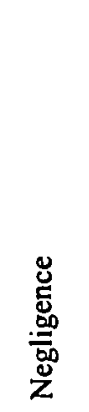 & $\frac{\tilde{\alpha}}{\stackrel{\infty}{\sigma}}$ & 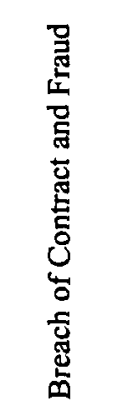 & 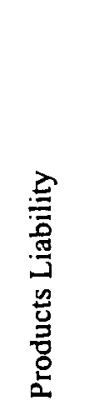 & 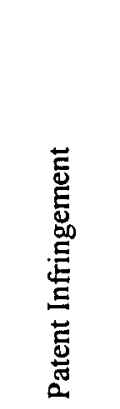 & 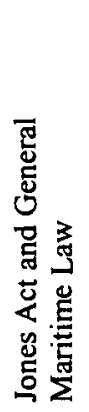 & 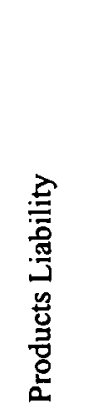 & 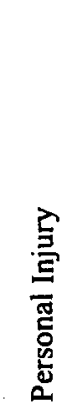 \\
\hline 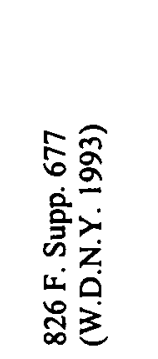 & 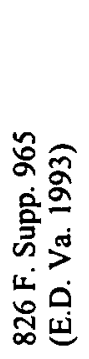 & 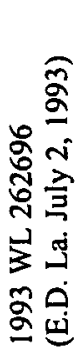 & 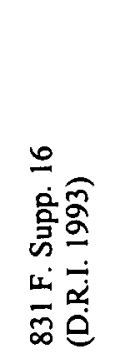 & 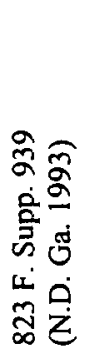 & 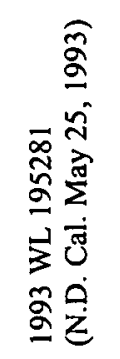 & 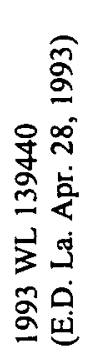 & 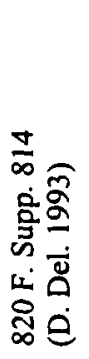 & 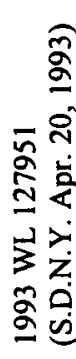 \\
\hline 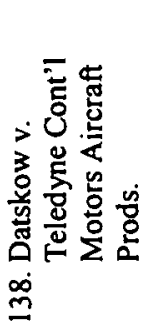 & 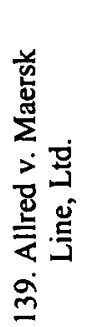 & 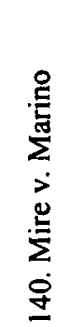 & 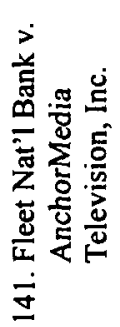 & 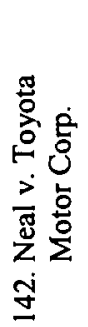 & 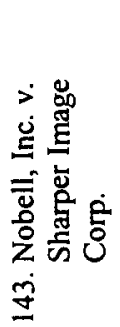 & 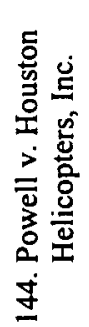 & 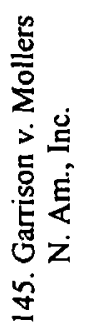 & 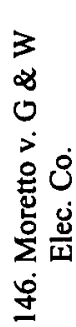 \\
\hline
\end{tabular}




\begin{tabular}{|c|c|c|c|c|c|c|c|c|}
\hline 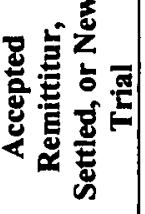 & 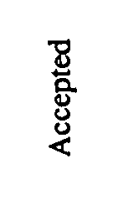 & 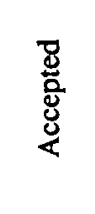 & 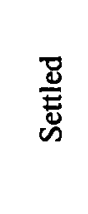 & $\begin{array}{l}\text { Z } \\
\stackrel{0}{0} \\
\stackrel{0}{0} \\
\&\end{array}$ & 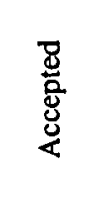 & 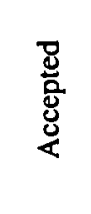 & 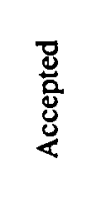 & 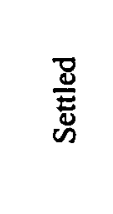 \\
\hline 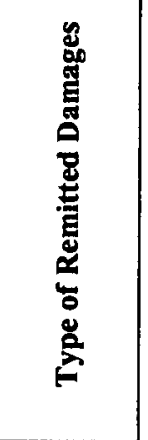 & 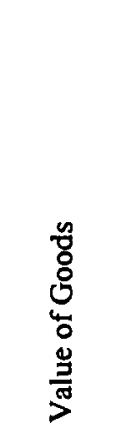 & 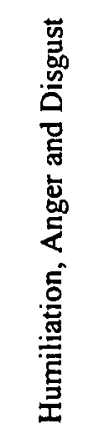 & 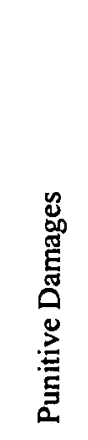 & 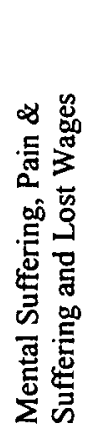 & 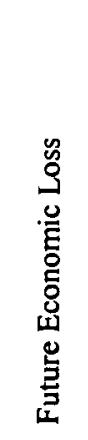 & 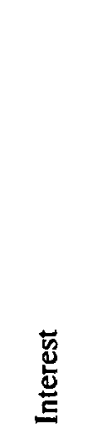 & 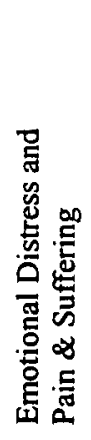 & 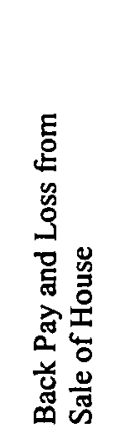 \\
\hline 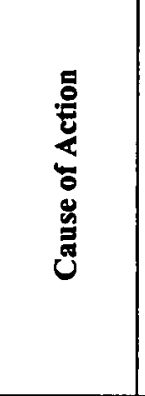 & 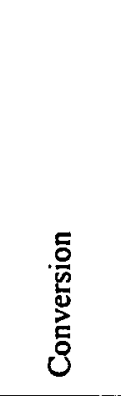 & 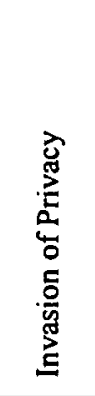 & 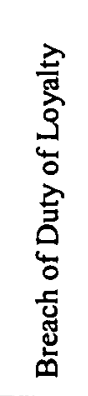 & 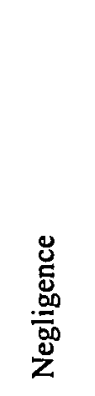 & 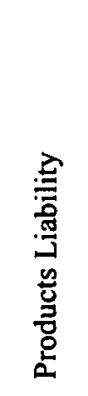 & 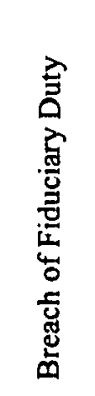 & $\frac{\tilde{\infty}}{\cos }$ & 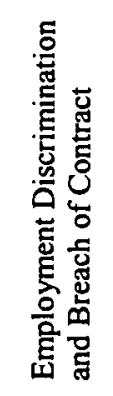 \\
\hline 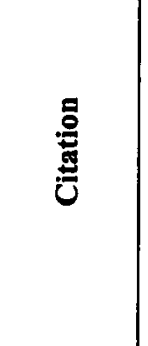 & 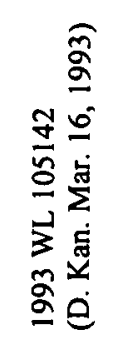 & 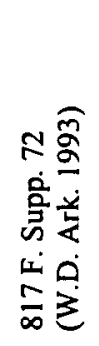 & 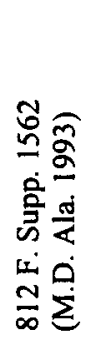 & 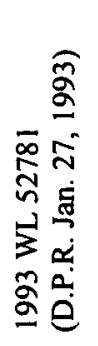 & 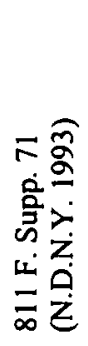 & 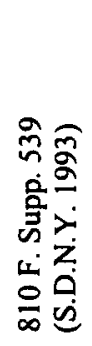 & 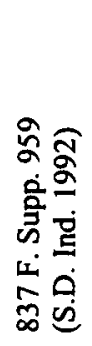 & 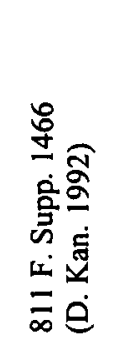 \\
\hline ర్ల్ర & 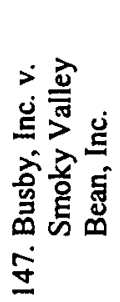 & 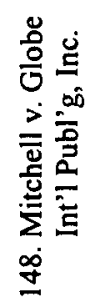 & 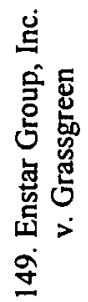 & 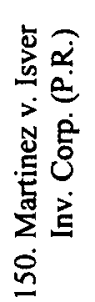 & 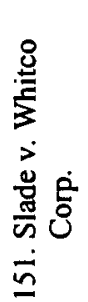 & 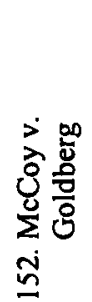 & 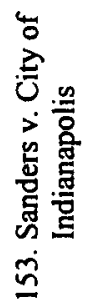 & 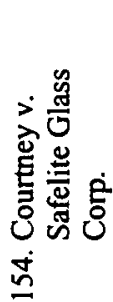 \\
\hline
\end{tabular}




\begin{tabular}{|c|c|c|c|c|c|c|c|}
\hline 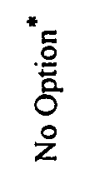 & 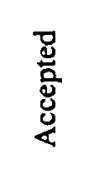 & 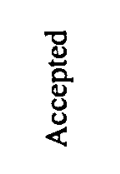 & 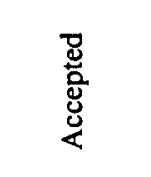 & 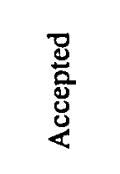 & 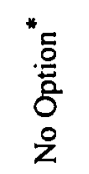 & 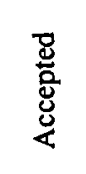 & 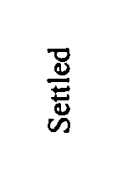 \\
\hline 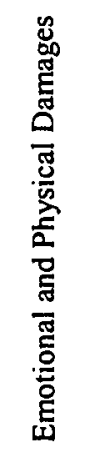 & 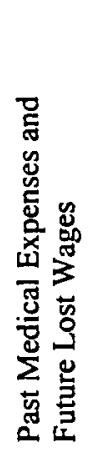 & 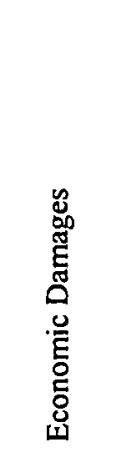 & 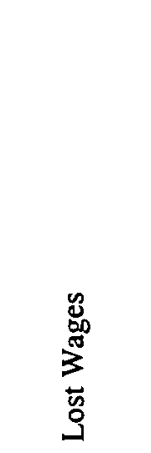 & 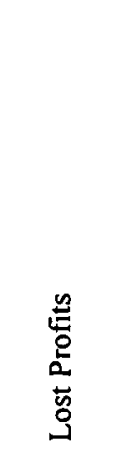 & 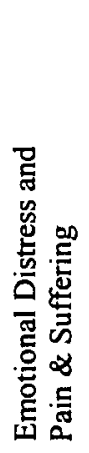 & 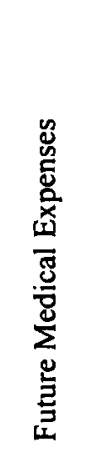 & 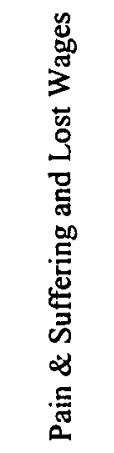 \\
\hline 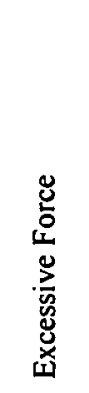 & 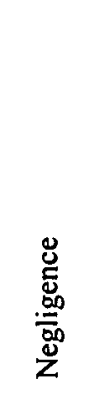 & $\begin{array}{l}\overrightarrow{0} \\
\frac{0}{0} \\
\frac{\sigma}{\sigma} \\
\frac{\sigma}{0}\end{array}$ & 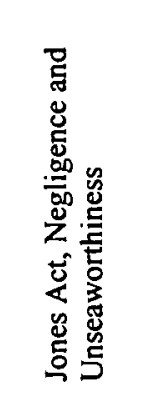 & 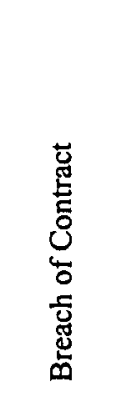 & 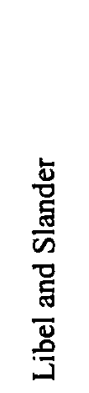 & 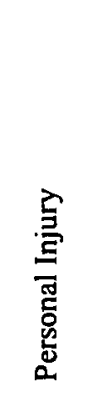 & 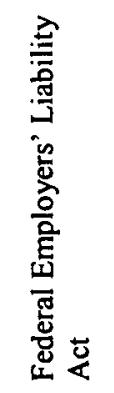 \\
\hline 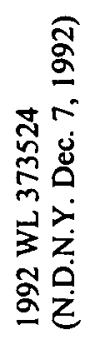 & 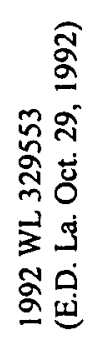 & 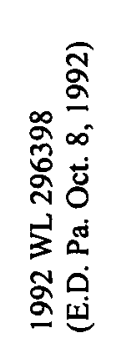 & 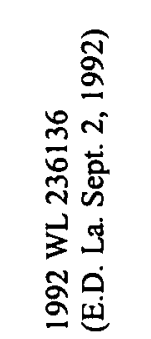 & 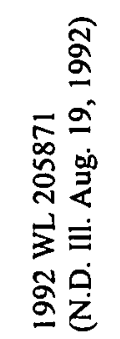 & 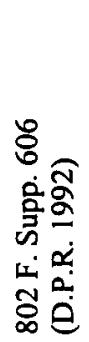 & 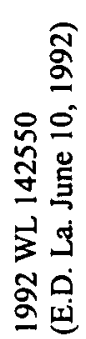 & 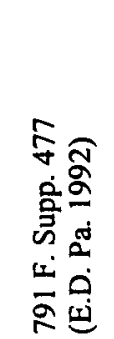 \\
\hline 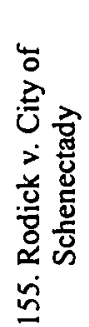 & 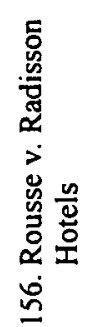 & 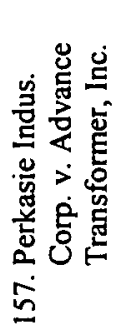 & 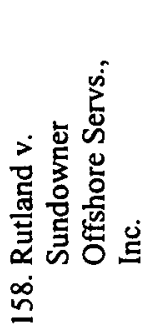 & 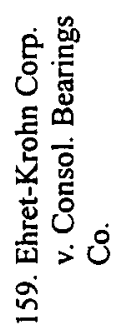 & 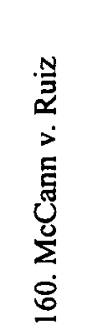 & 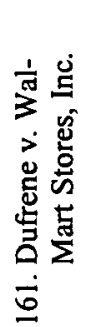 & 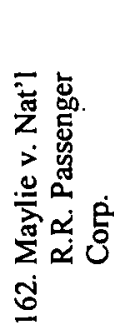 \\
\hline
\end{tabular}




\begin{tabular}{|c|c|c|c|c|c|c|c|}
\hline 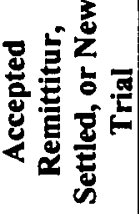 & 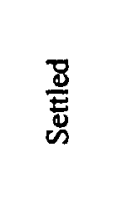 & 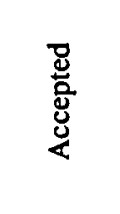 & 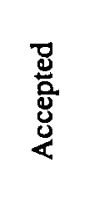 & 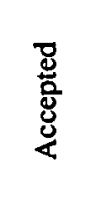 & 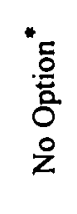 & 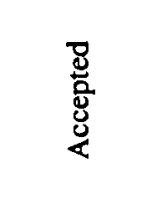 & 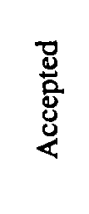 \\
\hline 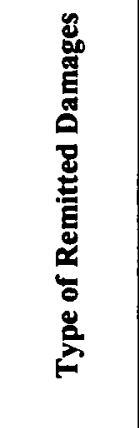 & 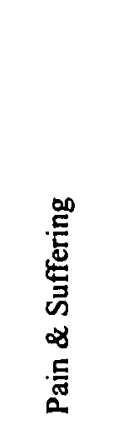 & 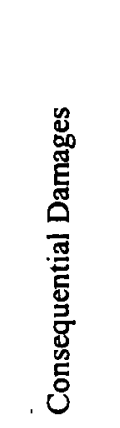 & 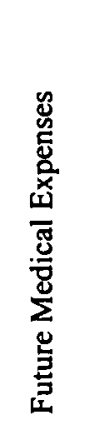 & 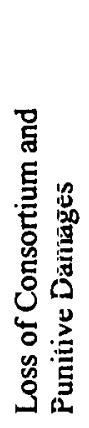 & 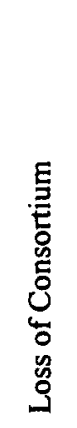 & 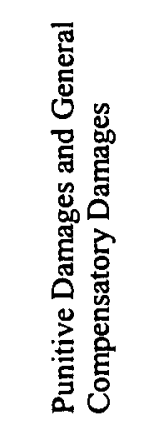 & 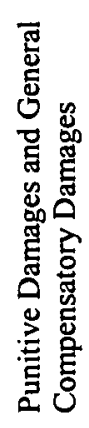 \\
\hline 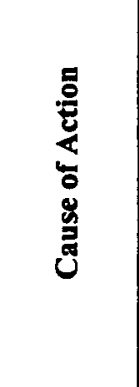 & 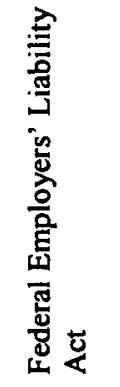 & 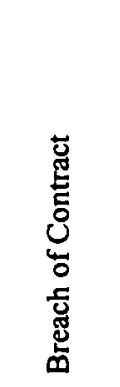 & 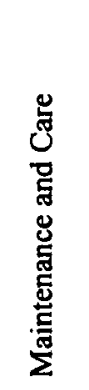 & 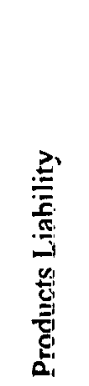 & 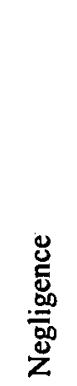 & 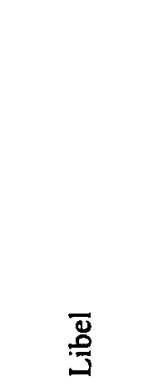 & 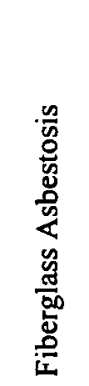 \\
\hline 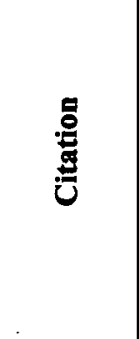 & 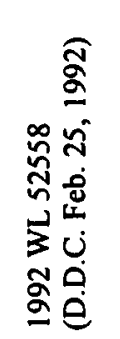 & 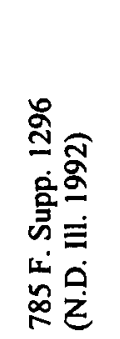 & 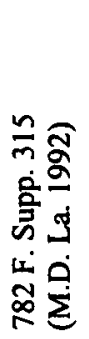 & 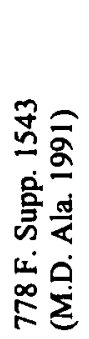 & 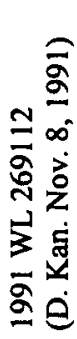 & 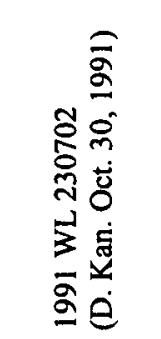 & 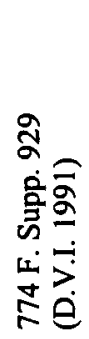 \\
\hline 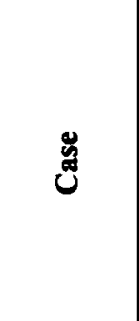 & 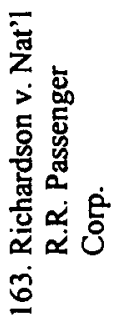 & 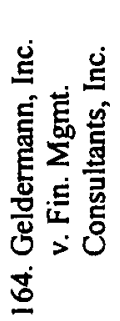 & 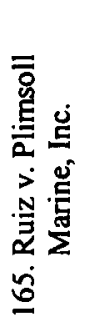 & 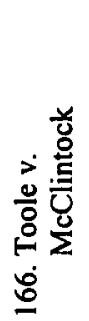 & 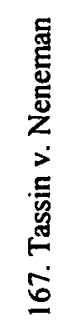 & 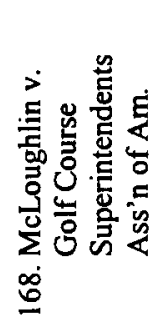 & 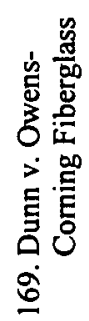 \\
\hline
\end{tabular}




\begin{tabular}{|c|c|c|c|c|c|c|c|c|}
\hline $\begin{array}{l}\text { D. } \\
\text { E्E } \\
\text { 心 }\end{array}$ & 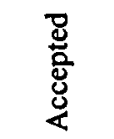 & 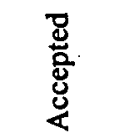 & 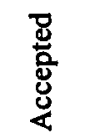 & $\begin{array}{l}\frac{D}{\mathbb{E}} \\
\text { E⿱ } \\
心\end{array}$ & 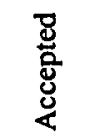 & $\begin{array}{l}\text { D. } \\
\text { E⿱巳巳心 } \\
\text { E. }\end{array}$ & 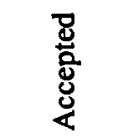 & 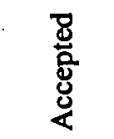 \\
\hline 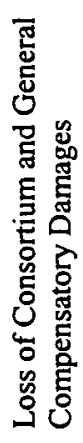 & 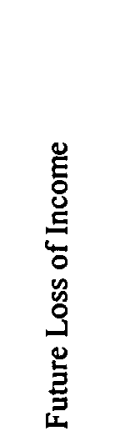 & 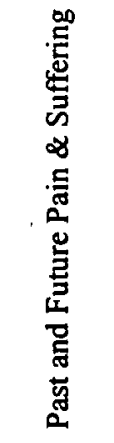 & 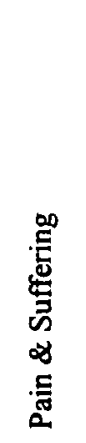 & 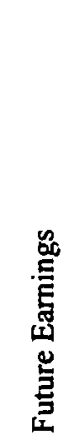 & 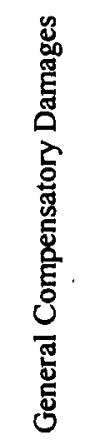 & 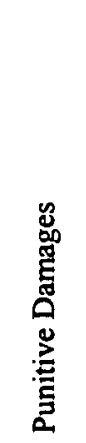 & 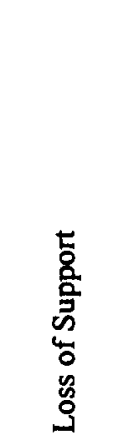 & 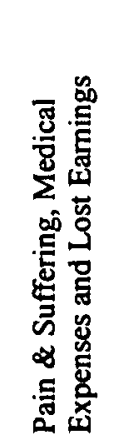 \\
\hline 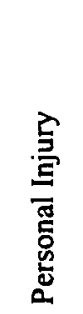 & 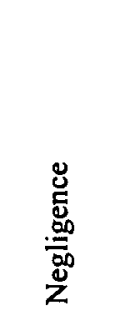 & 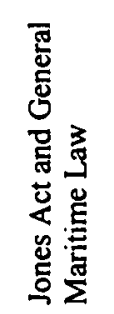 & 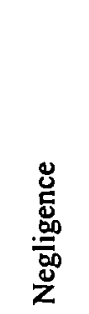 & 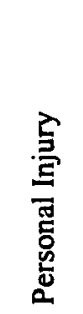 & 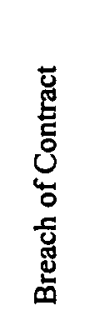 & $\frac{\mathscr{\infty}}{\stackrel{\infty}{\sigma}}$ & 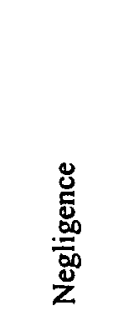 & $\stackrel{5}{\circ}$ \\
\hline 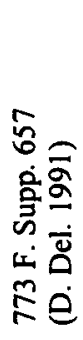 & 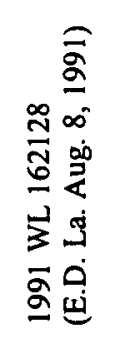 & 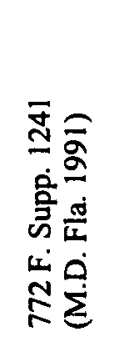 & 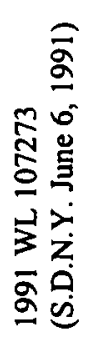 & 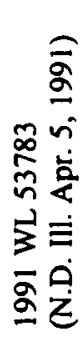 & 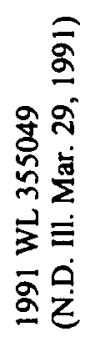 & 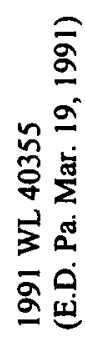 & 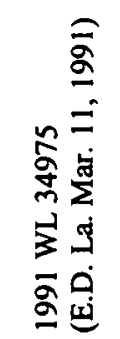 & 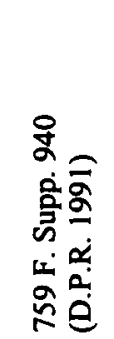 \\
\hline 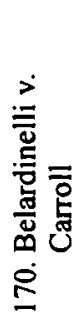 & 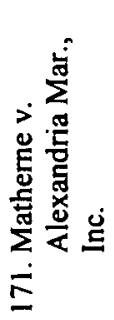 & 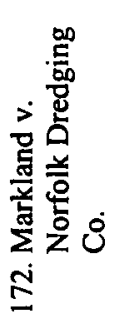 & 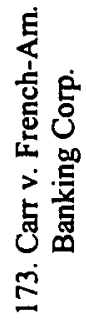 & 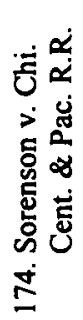 & 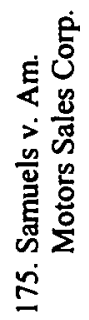 & 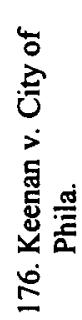 & 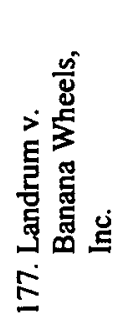 & 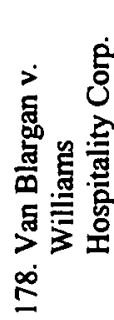 \\
\hline
\end{tabular}




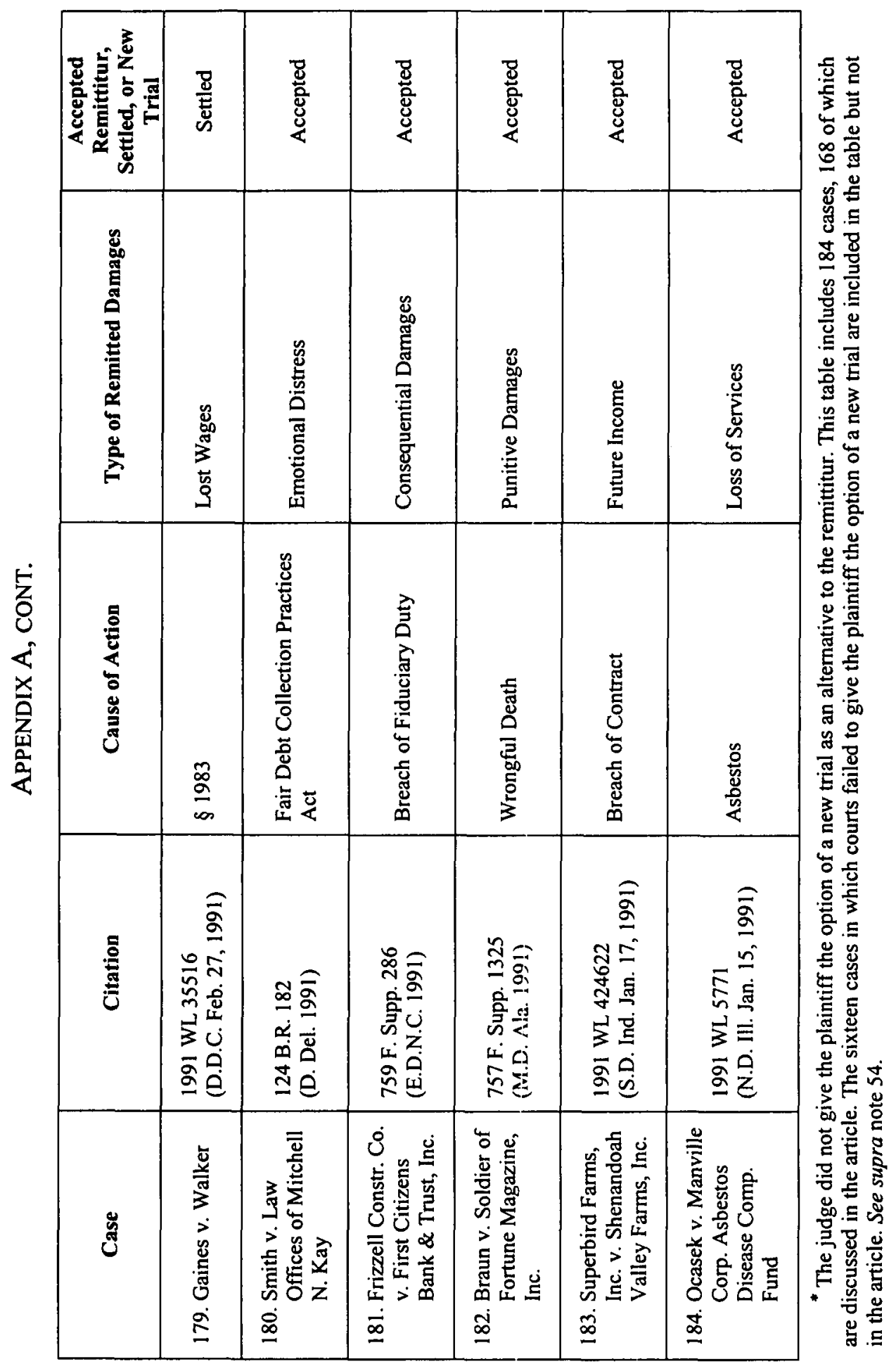

